CLAUDIO LUIZ LAZZARINI

\title{
Análise da confiabilidade do telediagnóstico por imagens dinâmicas em laringologia
}

Tese apresentada à Faculdade de Medicina da Universidade de São Paulo para obtenção do título de Doutor em Ciências.

Área de concentração: Otorrinolaringologia

Orientador: Prof. Dr. Luiz Ubirajara Sennes

SÃO PAULO

2004 
"O propósito do aprendizado é crescer, e nossas mentes, diferentes de nossos corpos, podem continuar crescendo enquanto continuamos a viver" 


\section{Dedicatória}

Arthur, meu querido filho que muitas vezes toma para si o papel de instrutor e mentor e, com muito menos tempo de existência, ensina sem perceber, lições de vida ao pai que por vezes se esquece de aprender com cada momento vivido.

Aos meus amados pais, Milton e Marisa, exemplos de amor, força, abnegção e dedicação. Nada teria conseguido se não fosse seu contínuo esforço e orientação. Personificações de dignidade cujos passos jamais exitei ou exitarei em seguir.

Haydèe e Deolinda, queridas avós, que durante toda minha vida foram exemplos de carinho e dedicação e ao final desta fase da minha trajetória partiram de nosso plano terrestre deixando saudades, porém a certeza de sua presença ainda mais intensa no restante da minha caminhada.

À querida Tatiana, companheira e amiga de todos os momentos. Obrigado pela paciência e pelo apoio nos momentos decisivos. Imensa fortaleza de grande caráter e personalidade marcante, utilizando sua força para alavancar-me nas situações de fraqueza e impelindo-me de encontro aos meus ideais. 


\section{Agradecimentos}

Ao grande mestre Prof. Dr. Aroldo Miniti, cuja energia e dedicação ao ensino foram a mola propulsora do Departamento e a de todos que nele trabalham.

Ao Prof. Dr. Luiz Ubirajara Sennes, pelo seu dinamismo indescritível e fantástica capacidade de avaliação e síntese. Cientista e amigo cujo papel na elaboração desta tese foi tão importante que, tenho absoluta certeza, não a teria terminado se não fosse sua orientação.

À Profa. Dra. Priscila Bogar Rapoport, querida ex-colega de residência que por seus inúmeros méritos e capacidades ajudou-me hoje a iniciar, elaborar e conduzir este estudo com as mais apuradas técnicas científicas.

Ao Prof. Dr. Ricardo Ferreira Bento, pelo seu dinamismo e por nos ter dado a chance de iniciar o desenvolvimento deste estudo no Departamento.

Ao Prof. Dr. Luiz Henrique Camargo Paschoal, diretor da Faculdade de Medicina do ABC, pela permissão para o uso das instalações da faculdade.

Ao Prof. Dr. György Böhm, professor titular do Departamento de Patologia da Faculdade de Medicina da USP, e responsável pela Disciplina de Telemedicina, pela permissão para o uso das instalações do departamento.

Ao Dr. Chao Lung Wen, coordenador geral da Disciplina de Telemedicina da Faculdade de Medicina da USP, por seu apoio incondicional ao desenvolvimento deste estudo.

Aos amigos Marcos, Márcia e toda a equipe da Disciplina de Telemedicina da Faculdade de Medicina da USP, por toda a ajuda técnica e científica. 
Aos amigos Wilson, Hélio e toda a equipe do Departamento de Informática Médica da Faculdade de Medicina do ABC, pela ajuda técnica e científica.

Aos colegas: Dr. Fernando Veiga Angélico Jr., Dr. José Roberto Parisi Jurado, Dr. Leonardo Haddad, Dr. Luis Antônio Prata Figueiredo, Dra. Roberta Ismael Dias Garcia, Dr. Rodrigo de Oliveira Santos, pela paciência e empenho no desenvolvimento deste estudo. Sem a sua colaboração o desenvolvimento desta tese não teria sido possível. Muito obrigado a todos.

Às secretárias e funcionários da Disciplina de Otorrinolaringologia e da PósGraduação: Bárbara, Edzira, Jorge, Lucy, Márcia, Marilede e Ofélia. Obrigado pelo apoio, orientação, presteza e pela simpatia com que sempre nos trataram.

À Dra. Mônica Aidar Menon Miyake pelas importantes orientações sobre as configurações e trâmites burocráticos que envolvem a confecção e registro da tese.

Aos colegas Prof. Dr. Domingos Hiroshi Tsuji, Dra. Roseli Saraiva Moreira Bittar e Dr. Ruy lamamura por terem aceito o convite para fazer parte da banca de qualificação, assim como a Dr. Rubens Vuono de Brito Netto e Dra. Patrícia Paula Santoro que estiveram na suplência. Agradeço por seus importantes conselhos para o bom andamento do estudo.

À Profa. Dra. Tanit Ganz Sanches pelas orientações científicas, apoio e dinamismo com que orientou a condução desta tese

Ao Prof. Dr. Renato Marcos Endrizzi Sabbatini e Dra. Silvia Helena Cardoso pela instrução, estímulo, apoio e inestimáveis conselhos científicos antes e durante o desenvolvimento deste estudo. Sem sua orientação minha caminhada pela telemedicina sequer teria se iniciado. Obrigado 
A Wagner, Rosana e toda a equipe do Instituto EDUMED pelo apoio técnico e científico.

À todos os colegas da pós-graduação por todos os momentos agradáveis vividos, pela amizade, parceria e possibilidade de intercâmbio de informações sejam elas técnicas, científicas ou de ordem pessoal.

À Andréia,cujos profundos conhecimentos de estatística foram fundamentais para análise dos resultados obtidos nesta tese.

À Rosa, Lola, Mário, Diego, Carmem, Tereza, Giuliana, Marcos e Ademar pelo apoio e paciência durante estes vários meses em que abdiquei do seu convívio para desenvolver esta tese.

À Patrícia, minha querida irmã, sempre disposta a ajudar e aconselhar.

À CAPPesq cuja bolsa fornecida nos auxiliou a concluir esta tese. 


\section{A. ARTIGO PARA PUBLICAÇÃO \\ B. TESE DE DOUTORAMENTO}

\section{LISTA DE ABREVIATURAS E SINAIS}

RESUMO

\section{SUMMARY}

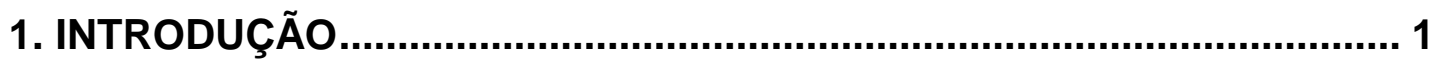

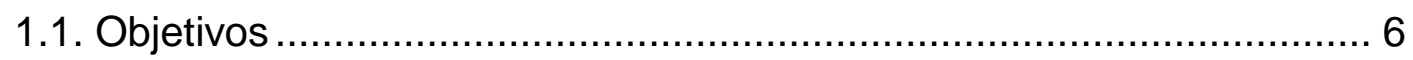

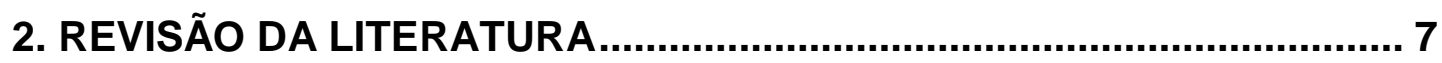

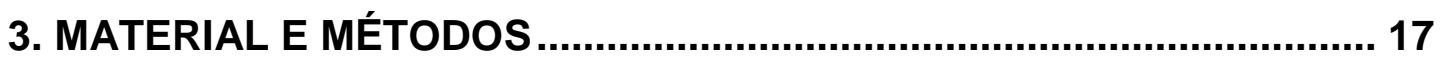

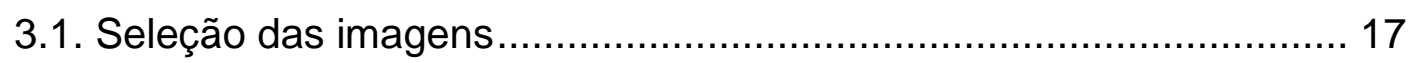

3.2. Digitalização das imagens ........................................................... 24

3.3. Captura das imagens para o disco rígido do computador:................... 26

3.4. Edição das imagens capturadas pelo disco rígido ............................ 30

3.5. Encadeamento e identificação das imagens editadas ....................... 31

3.6. Transmissão das fitas originais 1 e 2 por VC .................................. 32

3.7. Criação das conteúdos finais para gravação dos DVDs A e B .......... 36

3.8. Criação do DVD pareado (DVDPAR) …………………………..... 39

3.9. Análise dos examinadores .......................................................... 41

3.10. Análise da concordância diagnóstica nos DVDs A e B ………….... 46

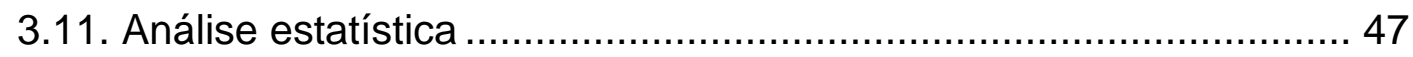

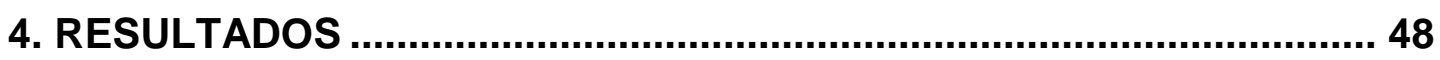

4.1. Avaliação do DVD de images pareadas (DVDPAR) ........................ 48 
4.1.1. Qual das duas imagens do par é a melhor?

4.1.2. A diferença das imagens afeta o diagnóstico?....................... 50

4.1.3. Qual das imagens é a de VC? ....................................... 52

4.2. Resultados da análise da qualidade da imagem nos DVDs A e B :... 54

4.3. Concordância diagnóstica nos DVDs A e B .................................. 56

5. DISCUSSÃO

5.1. Transmissão das imagens digitalizadas................................. 61

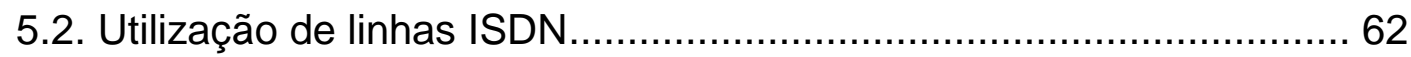

5.3. Análise da comparação de qualidade das imagens no DVDPAR ...... 63

5.4. Implicação da diferença da qualidade da imagem no diagnóstico .....64 64

5.5. Caracterização da imagem como sendo VC ...............................6 65

5.6. Análise da qualidade das imagens dos DVDA e DVDB ...................66 66

5.7. Análise do acerto diagnóstico ............................................6 68

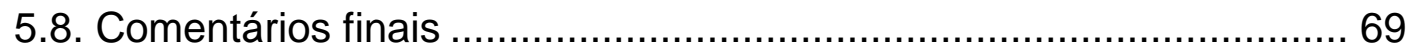

6. CONCLUSÕES.............................................................................. 71

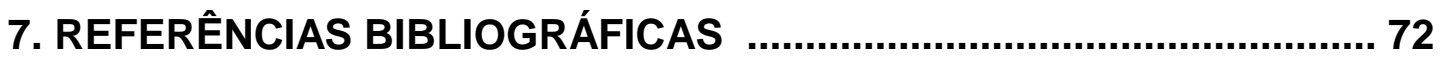




\section{A. ARTIGO PARA PUBLICAÇÃO}

Reliability of videolaryngoscopy images transmitted by videoconference.

Claudio Luiz Lazzarini ${ }^{\star}$, Luiz Ubirajara Sennes*, Priscila Bogar Rapoport** ${ }^{*}$ Otolaryngology Department, University of São Paulo, Brazil

**Otolaryngology Department, Medicine School of ABC, Brazil

Correspondence: Claudio Luiz Lazzarini, Rua Dr. Clementino, 456 - Ap 114B - São Paulo - Brasil - CEP 03059-030 (Fax: +55 116695 0068; E-mail: cllazza@terra.com.br) 


\section{Summary}

The present study aims to establish the level of diagnostic reliability provided by the transmission of a videolaryngoscopy by videoconference (VC), evaluating the quality of the transmitted images and its impact on diagnoses. Two DVDs with 60 laryngoscopy (30 fiberscopies and 30 telescopies) images, corresponding to 30 original and 30 transmitted by VC, were evaluated by 6 laryngologists who answered a questionnaire on the quality of the selected images (scores from 0 to 3 ) and on the diagnoses of the related disease. A third DVD with 26 pairs of images, an original and a VC, or two original, was also analyzed by the examiners who had to select which image presented the best quality, which corresponded to the VC image, and the possible impact of such differences on the quality of diagnoses. A high level of agreement $(K=0.911)$ was found among the examiners in relation to the identification of the VC $(96,15 \%$ of accuracy) and to the best quality of the original image $(K=0,850)$. Although a partial agreement has been found among the examiners $(K=0,371)$, diagnoses was not jeopardized by the quality of the VC image in $75,64 \%$ of the cases. Original videotelescopy images $(83,33 \%$ very good) showed the best quality and videofiberscopy VC the worst (36,66\% very good and good). A high degree of correctness was found for the diagnoses by VC images $(86,67 \%$ by fiberscopy and by telescopy). Consequently, the use of a VC to transmit videolaryngoscopy images has proved to be efficient for the remote diagnoses of larynx diseases.

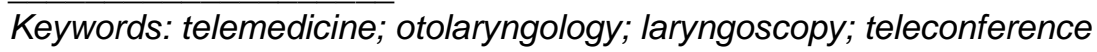




\section{Introduction}

Telemedicine (TM) delivers medical services via remote telecommunications, including interactive consultations and diagnoses services $^{1}$. TM has a great potential on otorhinolaryngology ${ }^{2,3}$, because of the use of video-documented images as a routine ${ }^{4}$. However, the quality of the transmitted image may represent an obstacle to TM, specially in laryngology, where diagnoses depends on detailed evaluation of extremely dynamic images.

The use of VC transmissions in several areas of otorhinolaryngology, such as clinic-diagnostic ${ }^{4-12}$, social-economic ${ }^{13-15}$, educational ${ }^{16,17}$, surgical ${ }^{17}$, and satisfactory doctor-patient relationship ${ }^{18}$ aspects, has been proved effective, stimulating the development and use of this type of communication.

The purpose of the present study is to compare the original images of videolaryngoscopies with those obtained by VC transmission:

1. Is it possible to differentiate an original from a VC transmitted image?

2. The quality of telescopy and fiberscopy images before and after a VC transmission are different?

3. Is there impact of VC image on diagnoses?

4. The impact on diagnoses is different for telescopies and fiberscopies?

\section{Methods}

Sixty videolaryngoscopy images (30 telescopies and 30 fiberscopies) with precise diagnoses were selected.

The selected images have been reproduced by a SEMP TOSHIBA video system model X688 and recorded in a video digital format (DV), in 
videotapes SONY Digital $8^{\circledR}$. Images were captured in a IBM PC Pentium IV $2 \mathrm{GHz}$ computer by a IEE1394 Firewire cable, and edited by a Pinnacle Studio Version 8.5.21.0 software. After edition, the images, in AVI format (720x480 pixels), were numbered and recorded on two Digital $8^{\circledR}$ tapes, soundless. These original images were transmitted from the University of Sao Paulo, from a digital camera (SONY TRV 340), connected through a Super VHS (SVHS) cable to a TANDBERG 6000 videoconference equipment, with 4 ISDN lines of $128 \mathrm{kpbs}$ from the telephone company of the State of Sao Paulo (Telefonica), that generated a communication rate of 512 Kbps.

The images were received at the ABC School of Medicine, by a POLYCOM View Station videoconference equipment, also connected to 4 ISDN lines of another telecommunication company (Embratel), with a communication rate of $512 \mathrm{Kbps}$. It was recorded on two Digital $8^{\circledR}$ tapes by another video digital SONY TRV 340 camera, connected to the equipment by a SVHS cable.

A technician followed the transmission and another the reception at the respective institutions. No unfavourable events were reported and the transmission proceeded stable and without oscillations. The transmission was performed according to the H.320 standard communication and H263 video protocols. The transmitted images were also captured in the computer and edited by Pinnacle Studio software in AVI format.

With the 60 pairs of images (an original and its correspondent VC image) two complementary DVDs were generated (A and B). Ramdomly, 
each DVD received one image of the pairs, completing 60 images, with 30 originals (15 telescopies and 15 fiberscopies) and 30 videoconferences (15 telescopies and 15 fiberscopies). A poor (score 0) and a very good (score 3) quality image were inserted at the beginning of the DVD to provide the examiner with a parameter to compare the images quality.

A third DVD (DVD-PAR) with paired images was prepared. Twenty-six (13 fiberscopies and 13 telescopies) selected pairs of images were sequentially placed, with randomized order of insertion (original or VC). In 6 cases, two original images were inserted.

Six laryngologists analyzed the DVDs using the same DVD player (SONY DVD-315) and monitor (TV PHILCO TPF-2121, SVHS flat screen, 21 inches), with same adjustment parameters. All examiners analyzed the DVDPAR answering which image of the pair corresponded to the VC (or if both were original), which presented the best quality, and if the quality difference could affect the diagnoses.

In relation to DVDs $A$ and $B, 3$ examiners analyzed the DVD-A and the other 3 the DVD-B. They judged the image quality (scores from 0 to 3 representing respectively poor, regular, good and very good images), the diagnoses and described the hypopharynx and larynx. Two referees evaluated the score of quality and the diagnoses offered by the 6 examiners (3 DVD-A and 3 DVD-B). The most frequent opinion from each 3 examiners was considered the image score of quality. The diagnoses was considered as correct when both diagnoses and description were correct; partially correct when the diagnoses was incorrect, but the description was correct 
and incorrect when both were incorrect. When the referees disagreed, a final consensus was attained.

The statistical analyses applied to the answer agreement used the Kappa coefficient ${ }^{19}$ and the weighted Kappa coefficient (used for more than two instances), considering 0.75 to 1.00 as a very good agreement; 0.4 to 0.74 from regular to good; and less than 0.35 as poor.

\section{Results}

In analysis of DVD-PAR, the examiners identified and pointed the original image as the best $(p<0.001)$ (Tables 1 and 2$)$. However, they considered the quality of $\mathrm{VC}$ image as a non-jeopardizing factor for diagnoses in $75.64 \%$ of cases (Table 3). Analyzing DVDs A and B, they always considered the original images better or equal than $\mathrm{VC}$ in fiberscopies and telescopies (Tables 4 and 5).

In fiberscopies the diagnoses was completely correct in $90 \%$ of the original images and in $86,67 \%$ of VC images (Table 6). In telescopies, it was correct in $96.67 \%$ of original images and $86.67 \%$ of VC images (Table 7 ).

\section{Discussion}

All multimedia material, may be captured and converted to a digital format with minimal losses of quality ${ }^{20,21}$. After the digitalization, each video frame is a static image that is pixalized (subdivided into small unities pixels). The quality of a digitalized video will depend on the number of frames captured per second and on the quality of each frame, expressed by the pixels amount used (the dimension of the screen) and by the information amount contained in each pixel (range of colors). 
So, digitalization requires a great storage space. Therefore, to make a transmission viable, a reduction of the data of such image is required ${ }^{4}$. The CODEC (coder/decoder) is a mathematical algorithm-based system to compress redundant data, which reduce the amount of information to be transmitted ${ }^{22}$ and received. We adopted the most used CODEC communication (H 320) and compacting $(\mathrm{H} 263)$ protocol $^{23}$. The main reasons for delays in VC are latency (delay to spread the data on the net) and jitter (deliver of data packages with variable latency). In VC, the minimum bandwith acceptable for audio is $71 \mathrm{Kbps}$ and for video is $128 \mathrm{Kbps}^{22}$.

An ISDN line with 128 Kbps makes possible to transmit monophonic audio (TV quality) and video limited to 15 frames per second, unable to show fast movements. The use of 3 ISDN lines (constant transmission rate assured band ${ }^{24}$ ) provides $384 \mathrm{Kbps}$, offering an excellent VC quality with 30 frames per second ${ }^{25}$.

Pedersen ${ }^{4}$, in his pioneering work on VC applied to otolaryngology, in 1994 , concluded that a video in full screen, with resolution of $410 \times 400$, would require about 1,000 phone lines to be conducted; however, using a CODEC this number could be reduced by $97 \%$ to 32 channels (16 lines).

Even though, the use of 8 channels (4 ISDN lines) or $512 \mathrm{Kbps}$ is much more realistic. We used this configuration, analyzing the impact of such compression (loosing quality and reducing number of colors) blurring the most delicate structures and delaying the frames updating in videolaryngoscopies. 
The transmission between this 2 Institutions simulated a frequently condition in VC between distant points: good equipments (Tandberg 6000 and Polycom), but from different brands, connected by 4 ISDN lines of 128 Kbps of different companies (Telefonica and Embratel), in an inter-county transmission. We recorded the images in DVD, DVD-R format, that is a stable media with an imperceptible quality loss.

The literature on the use of TM in laryngology is scanty, mainly in laryngology. Furukawa ${ }^{12}$ studied only static images for diagnoses. Sclafani ${ }^{5}$, in 1999, used images from a nasofiberscope as part of a general consultation and transmission at $384 \mathrm{Kbps}$. We study the videolaryngoscopy transmission with $512 \mathrm{Kbps}$ and differentiation between fiberscopy and telescopy.

In the original-VC pairs evaluation (DVD-PAR), all examiners found the original quality better than VC image, with high agreement between them, both for fiberscopy and telescopy. All disagreement were from examiners who considered both images as original, in spite one was a VC image, showing that the quality was quite good to be mistaken by an original one (Table 1).

In $96.15 \%$ of the cases, the examiners identified the VC image. In telescopies it was pointed in all cases and in fiberscopies in $92.30 \%$. The fiberscopy images are smaller and show a surrounding dark region constantly present in the screen (due to the use of a coupler and to the fiberscope lens diameter). This region is considered non-active by the CODEC for video compression, which keeps its complete processing capacity in the dynamic central region of the screen, improving the quality of 
the final transmission. In telescopies the full screen image with simultaneous movement on a great number of points causes dispersion of the processing capacity of the CODEC. We also observed that VC images with greater movement of analyzed structures have been considered worse than the originals, what also can be explained by CODEC process difficult, loosing quality and leading to easily identification by examiners.

The quality of VC image showed no significant interference in the diagnoses in $76.92 \%$ of the fiberscopies and in $74.35 \%$ of the telescopies, even when unanimity was not found among the examiners. Among fiberscopies, 3 laryngoscopies were considered technically poor (dark, with great movement), impairing the analysis. Only 1 exam among the telescopies was considered technically poor, in that the impaired diagnoses resulted from the pixalization process by VC.

The DVDs A and B are complementary; that is, they present only one image of the pair (original or VC). As 3 examiners evaluated the DVD-A and the other 3 the DVD-B, the result was considered the most frequent score of each group of examiners. Analyzing the attributing scores, we confirmed the difference between the qualities of original and VC images, always in favor of the original one (better in $83.33 \%$ and equal in $16.67 \%$ ), meaning that the transmission effectively causes image deterioration.

Again, in telescopies this perception was more evident $(K=0.059)$ : VC images was worse than original in $90.00 \%$, while in fiberscopies this happened in $76.67 \%(K=0.249)$. The telescopy has a so good image (very good in $83.33 \%$ ) that small changes are perceivable, even considering that 
VC quality was considered good in $73.33 \%$ (Table 5 ). On the other hand, as the quality of original fiberscopy is not as good (only $43.33 \%$ are very good), a small loss of quality may not be perceived (3.33\% very good and $33.33 \%$ good) (Table 4). In this study the images quality followed a decreasing order of quality: original telescopies, original fiberscopies, VC telescopies, and VC fiberscopies.

The optical system can explain the differences of quality. In the fiberscope, a beam of tiny optical fibers provides a granulated and discontinuous aspect to the final image. In the telescope, an assemblage of lenses transmits the image, providing the final image with a non-granulated continuous aspect. Although better, the telescopy image is bigger (full screen), impairing the process of the CODEC and the VC transmission. We can assume that the better image to be transmitted by VC would be obtained by a telescope, but with a coupler that generates an image smaller than a full screen.

As 3 examiners observed DVD-A and the other 3 analyzed the complementary images (DVD-B), 2 independent referees evaluated their diagnoses and descriptions. No matter if the image resulted from a fiberscopy or a telescopy, the percentage of total diagnostic correctness in VC was very high for both groups, $86,67 \%$ in fiberscopies (Table 6) and $86.67 \%$ in telescopies (Table 7). Considering total and partial correctness the result was of $96,67 \%$ and $90,00 \%$, respectively.

With 512 Kbps (4 ISDN lines) we obtained similar findings to those of Pedersen ${ }^{4}$, with 16 ISDN lines, which showed that the quality difference from 
the VC image means no interference in the ability to determine a correct diagnoses. In addition, we observed that reliable diagnoses could be achievable for either fiber or telescopies, with a VC viable format for most of the institutions.

Furukawa $^{12}$, through two static image transmissions (one during a phonation and the other during respiration), considered that a general practice physician, other than a ORL, would have difficulties to understand the two phases of the image and suggested that new information should be provided. The present study fulfills this gap transmitting the image dynamically, making the local exam feasible to general practice physicians.

Consequently, general practice doctors with no otorhinolaryngology expertise may record larynx images to be transmitted to far located experts, using a rigid or flexible endoscope ${ }^{26}$. In this way, accurate images may be transmitted from distant regions in need of experts to be diagnosed, with reduced costs to patients, doctors, and public institutions, as well as achieving a more agile diagnoses for diseases that require more urgent treatment.

\section{Conclusion}

After the present study, we could conclude that the difference of image quality transmitted with $512 \mathrm{Kbps}$, both in larynx fiberscopies and telescopies is quite clear when comparing an original and VC transmitted image, always in favor of the original. The worst quality for a VC was found in fiberscopy.

Examiners are able to make a clear differentiation for a larynx image by fiberscopy and telescopy when transmitted by VC, although this difference 
shows no significant influence on the accuracy of the diagnoses in both cases.

\section{References}

1. National Library or Medicine. Medical Subject Headings, 1993

2. Uloza V, Almquist LO, Rydell R, Svensson O, Uloziene I. SwedishLithuanian telemedicine Litmed project in otolaryngology. Int Congr Ser $2003 ; 1240: 1407-1410$

3. Goldenberg D, Wenig BL. Telemedicine in Otolaryngology. Am J Otolaryngol 2002; 23:35-43

4. Pedersen S, Hartviksen G, Haga D. Teleconsultation of patients with otorhinolaringologic conditions. Arch Otolaryngol Head Neck Surg 1994; $120: 133-136$

5. Sclafani AP, Heneghan C, Ginsburg J, Sabini P, Stern J, Dolitsky JN. Teleconsultation in otolaryngology: Live versus store and forward consultations. Otolaryngol Head Neck Surg 1999; 120:62-72

6. Stern J, Heneghan C, Sclafani AP, Ginsburg J, Sabini P, Dolitsky JN. Telemedicine applications in otolaryngology. J Telemed Telecare 1998; 4:74-75

7. Ullah R, Gilliland D, Adams D. Otolaryngology consultations by real-time medicine. Ulster Med J 2002; 71:26-9

8. Burgess LPA, Holtel MR, Syms MJ, Birkmire-Peters DP, Peters LJ, Mashima PA. Overview of Telemedicine applications for otolaryngology. Laryngoscope 1999; 109:1433-1437 
9. Crump WJ, Driscoll B. An application of telemedicne technology for otorhinolaryngology diagnosis. Laryngoscope 1996; 106:595-598

10. Blakeslee DB, Grist WJ, Stachura ME, Blakeslee BS. Practice of otolaryngology via telemedicine. Laryngoscope 1998; 108:1-7

11. Patricoski C, Kokesh J, Ferguson S, et al. A comparison of in-person examination and video otoscope imaging for tympanostomy tube followup. Telemed J E Health 2003; 9:331-344

12. Furukawa M, Furukawa MK, Mizojiri G, Matsuda H. Telemedicine in Laryngology. Telemed J 1998; 4:329-333

13. Bergmo TS. An economic analysis of teleconsultation in otorhinolaryngology. J Telemed Telecare 1997; 3:194-199

14. Fortin JP, Gagnon MP, Cloutier A, Labbe F. Evaluation of a telemedicine demonstration project in the Magdalene Islands. J Telemed Telecare 2003; 9:89-94

15. Aas IH. Telemedical work and cooperation. J Telemed Telecare 2001; $7: 212-218$

16. Heneghan C, Sclafani AP, Stern J, Ginsburg J. Telemedicine applications in otolaryngology. IEEE Eng Med Biol Mag 1999; 18:53-62

17. Burgess LPA, Syms MJ, Holtel MR, Birkmire-Peters DP, Johnson, RE, Ramsey, MJ. Telemedicine: teleproctored endoscopic sinus surgery. Laryngoscope 2002; 112:216-219

18. Pedersen S, Holand U. Tele-endoscopic otorhinolaryngological examination: preliminary study of patient satisfaction. Telemed J 1995; $1: 47-52$ 
19. Cohen J. A coefficient of agreement for nominal scales, Educ Psychol Meas 1960; 20: 37-46.

20. Nunes L, Magalhães AP, Madeira S, et al. Sistemas pictográficos de comunicação alternativa para portadores de paralisia cerebral. IV Congressop RIBIE, Brasília, 1998

21. Mandel A, Simon I, Lyra JL. Informação: computação e comunicação. Revista USP 1997; 35: 11-45

22. Leopoldino GM. Avaliação de sistemas de videoconferência. Masters's degree dissertation - Instituto de Ciências Matemáticas e de Computação de São Carlos - Universidade de São Paulo, 115 p., 2001

23. Bordignon MR. Implementando aplicações de videoconferência em redes de computadores - http://www.networkdesigners.com.br/Artigos/ video/video.html. Last checked 1 July 2004

24. Costa FC.Recomendação H.243 - Procedimentos para estabelecer comunicação entre 3 ou mais terminais audiovisuais usando canais digitais de até 1920 kbits/s). Interinstitucional Master's Degree UFRGS/UFPA, 2000

25. Sabbatini RME. Utilizando Teleconferência em Medicina. Revista Médico Repórter 2000; 16: 22-24

26. DeWitt DE. Fiberoptic rhinolaryngoscopy in primary care: a new direction for expanding in-office diagnostics. Postgrad Med 1988; 84:125-144 
Table 1: AGREEMENT AMONG THE 6 EXAMINERS ABOUT WHICH IMAGE PRESENTED THE BEST QUALITY

videolaryngoscopies

fiberscopies + telescopies fiberscopies telescopies

$\mathrm{K}=$ Kappa coefficient $p=p$-value agreement $\mathrm{K}(\mathrm{p})$ $0.850(\mathrm{p}<0.001)$

$0.736(\mathrm{p}<0.001)$ $0.960(p<0.001)$ original is better(\%)

92,95

87,17

98.71 
Table 2: AGREEMENT AMONG THE 6 EXAMINERS ABOUT WHICH IMAGE OF THE PAIR WAS TRANSMITTED BY VC

\begin{tabular}{ccc}
\hline videolaryngoscopies & agreement K(p) & which one is VC(\%) \\
\hline fiberscopies + telescopies & $0.911(\mathrm{p}<0.001)$ & 96.15 \\
fiberscopies & $0.821(\mathrm{p}<0.001)$ & 92.30 \\
telescopies & $1.000(\mathrm{p}<0.001)$ & 100.00 \\
\hline
\end{tabular}

$\mathrm{K}=$ Kappa coefficient $\mathrm{p}=\mathrm{p}$-value 
Table 3: AGREEMENT AMONG THE 6 EXAMINERS IF THE QUALITY DIFFERENCE COULD AFFECT THE DIAGNOSES.

\begin{tabular}{ccc}
\hline videolaryngoscopies & agreement $K(p)$ & $\begin{array}{c}\text { difference do not affect } \\
\text { the diagnoses(\%) }\end{array}$ \\
\hline fiberscopies + telescopies & $0.371(p<0.001)$ & 75.64 \\
fiberscopies & $0.624(p<0.001)$ & 76.92 \\
telescopies & $0.060(p=0.201)$ & 74.35 \\
\hline
\end{tabular}

$\mathrm{K}=$ Kappa coefficient

$p=p$-value 
Table 4: QUALITY SCORES OF THE ORIGINAL AND VC IMAGES FOR FIBERSCOPIES

\begin{tabular}{|c|c|c|c|c|c|c|}
\hline & \multicolumn{5}{|c|}{ original images } \\
\hline & & poor & regular & good & very good & total \\
\hline \multirow{9}{*}{ 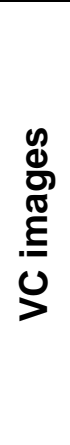 } & \multirow{2}{*}{ poor } & 0 & 3 & 1 & 1 & 5 \\
\hline & & $0.00 \%$ & $10.00 \%$ & $3.33 \%$ & $3.33 \%$ & $16.67 \%$ \\
\hline & \multirow{2}{*}{ regular } & 0 & 2 & 7 & 5 & 14 \\
\hline & & $0.00 \%$ & $6.67 \%$ & $23.33 \%$ & $16.67 \%$ & $46.67 \%$ \\
\hline & \multirow{2}{*}{ good } & 0 & 0 & 4 & 6 & 10 \\
\hline & & $0.00 \%$ & $0.00 \%$ & $13.33 \%$ & $20.00 \%$ & $33.33 \%$ \\
\hline & very & 0 & 0 & 0 & 1 & 1 \\
\hline & good & $0.00 \%$ & $0.00 \%$ & $0.00 \%$ & $3.33 \%$ & $3.33 \%$ \\
\hline & total & $\begin{array}{r}0 \\
0.00 \%\end{array}$ & $\begin{array}{r}5 \\
16.67 \%\end{array}$ & $\begin{array}{r}12 \\
40.00 \%\end{array}$ & $\begin{array}{r}13 \\
43.33 \%\end{array}$ & $\begin{array}{r}30 \\
100.00 \%\end{array}$ \\
\hline
\end{tabular}


Table 5: QUALITY SCORES OF THE ORIGINAL AND VC IMAGES FOR TELESCOPIES original images

\begin{tabular}{|c|c|c|c|c|c|c|}
\hline & & poor & regular & good & very good & total \\
\hline \multirow{10}{*}{ 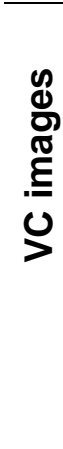 } & \multirow{2}{*}{ poor } & 0 & 0 & 1 & 0 & 1 \\
\hline & & $0.00 \%$ & $0.00 \%$ & $3.33 \%$ & $0.00 \%$ & $3.33 \%$ \\
\hline & \multirow{2}{*}{ regular } & 0 & 0 & 1 & 6 & 7 \\
\hline & & $0.00 \%$ & $0.00 \%$ & $3.33 \%$ & $20.00 \%$ & $23.33 \%$ \\
\hline & \multirow{2}{*}{ good } & 0 & 0 & 3 & 19 & 22 \\
\hline & & $0.00 \%$ & $0.00 \%$ & $10.00 \%$ & $63.33 \%$ & $73.33 \%$ \\
\hline & \multirow{2}{*}{$\begin{array}{l}\text { very } \\
\text { good }\end{array}$} & 0 & 0 & 0 & 0 & 0 \\
\hline & & $0.00 \%$ & $0.00 \%$ & $0.00 \%$ & $0.00 \%$ & $00.00 \%$ \\
\hline & \multirow{2}{*}{ total } & 0 & 0 & 5 & 25 & 30 \\
\hline & & $0.00 \%$ & $0.00 \%$ & $16.67 \%$ & $83.33 \%$ & $100.00 \%$ \\
\hline
\end{tabular}


Table 6: EXAMINERS DIAGNOSES FOR FIBERSCOPY IMAGES

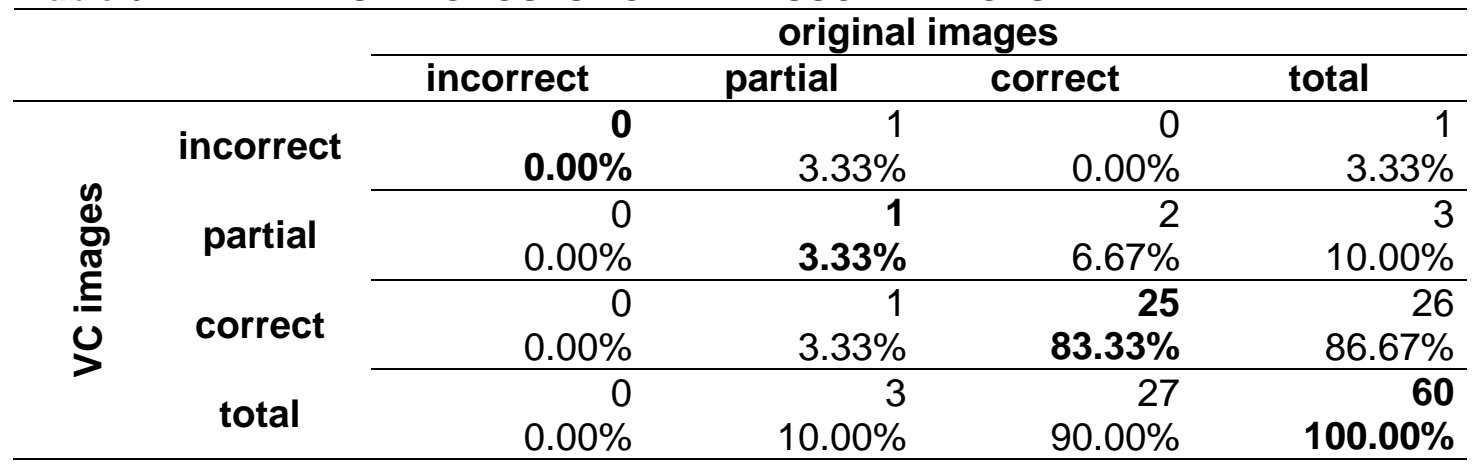


Table 7: EXAMINERS DIAGNOSES FOR TELESCOPY IMAGES

original images

\begin{tabular}{|c|c|c|c|c|c|}
\hline & \multirow[b]{2}{*}{ incorrect } & \multirow[b]{2}{*}{ partial } & \multirow[b]{2}{*}{ correct } & \multirow[b]{2}{*}{ total } \\
\hline & & & & & \\
\hline \multirow{4}{*}{ 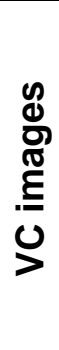 } & incorrect & $\begin{array}{r}0 \\
0.00 \%\end{array}$ & $\begin{array}{r}0 \\
0.00 \%\end{array}$ & $\begin{array}{r}3 \\
10.00 \%\end{array}$ & $\begin{array}{r}3 \\
10.00 \%\end{array}$ \\
\hline & partial & $\begin{array}{r}0 \\
0.00 \%\end{array}$ & $\begin{array}{r}1 \\
3.33 \%\end{array}$ & $\begin{array}{r}0 \\
0.00 \%\end{array}$ & $\begin{array}{r}1 \\
3.33 \%\end{array}$ \\
\hline & correct & $\begin{array}{r}0 \\
0.00 \%\end{array}$ & $\begin{array}{r}0 \\
0.00 \%\end{array}$ & $\begin{array}{r}26 \\
86.67 \%\end{array}$ & $\begin{array}{r}26 \\
86.67 \%\end{array}$ \\
\hline & total & $\begin{array}{r}0 \\
0.00 \% \\
\end{array}$ & $\begin{array}{r}1 \\
3.33 \% \\
\end{array}$ & $\begin{array}{r}29 \\
96.67 \%\end{array}$ & $\begin{array}{r}30 \\
100.00 \% \\
\end{array}$ \\
\hline
\end{tabular}




\title{
Journal of Telemedicine and Telecare
}

\author{
Guidelines for Authors
}

\begin{abstract}
Aims and scope
Telemedicine has been defined in general terms to be 'medicine practised at a distance' and as such it encompasses both diagnoses and treatment, as well as medical education. During the last decade certain telemedicine applications, such as videoconsulting and teleradiology, have matured to become essential health-care services. Others, such as telepathology, remain the subject of intensive research effort. The Journal of Telemedicine and Telecare is the first academic journal intended specifically for publication of peer-reviewed papers on all aspects of telemedicine and telecare, including online health and e-health.
\end{abstract}

\section{Editorial policy}

Contributions on all aspects of telemedicine and telecare, telehealth, online and e-health - whether human or animal — will be considered for publication, but material must not be submitted if it has been published previously in any printed or electronic media, including the Web. All papers will be reviewed by independent referees; the final decision about acceptance or rejection remains with the Editor. Papers on which the Editor is a co-author are handled by another member of the Editorial Board and are normally sent to at least two independent referees. The authors of all material accepted for publication will be required to assign copyright to the publishers, the Royal Society of Medicine Press, and a form for this purpose will accompany the proofs.

\section{Submissions}

Contributions in the following categories will be considered: original articles, preliminary communications, review articles, case reports and letters to the Editor. Unsolicited book reviews will not be considered for publication. Typescripts must be accompanied by the covering letter provided here as a template (see JTT covering letter template) and must be signed by all authors. Typescripts should be prepared in accordance with the guidelines given below and should be submitted by post: one copy of the typescript should be on floppy disk or CD-ROM (together with digital images of any figures) and two copies printed on paper. They should be sent to:

The Editor, Journal of Telemedicine and Telecare, Centre for Online Health, Level 3, Foundation Building, Royal Children's Hospital, Herston, QLD 4029, AUSTRALIA, Fax +61 733464705.

An editorial decision will normally be made within four weeks of receipt of the paper. The editorial process is likely to be expedited in the case of articles with a total length of less than 3000 words. 


\section{Preparation of typescripts \\ Format}

Typescripts may be prepared using any word-processing software, but see below regarding the requirements of submission. Use plain, unjustified text throughout, with subheadings in bold upper and lower case (not underlined). Press ENTER (carriage return) only at the end of each paragraph, each subheading, and each entry of a list. Avoid using footnotes and automatically numbered notes and paragraphs. Tables and figure legends should appear on separate pages at the end of the typescript. The text file (incorporating all tables and figure legends, but not the figures themselves) must be exported (or 'saved as') an RTF file (i.e. in 'rich text format'). Figures must be submitted as high-quality, camera-ready artwork. Line artwork should be included on disk in WMF format (i.e. as 'Windows meta-files'); photographic images should be included as TIFF or JPEG files at a resolution of $300 \mathrm{dpi}$.

\section{Title page}

This should contain: (1) the full title of the paper; (2) the names of all authors; (3) the department(s) and institution(s) where the work was carried out; (4) the name and address of the author responsible for correspondence about the typescript and proofs. Note that the editorial process will be speeded up if the author for correspondence can give an email address and a fax number.

Text

Original articles and preliminary communications should carry a summary of about 200 words, which states the main purposes of the study, the basic procedures used and the most important conclusions drawn. The rest of the paper should be structured in conventional style (Introduction, Methods, Results, Discussion, Acknowledgements, References).

Review articles also require a summary, indicating the scope of the review, the methods used to retrieve the relevant literature, the principal findings and conclusions drawn. Subheadings should be used within the article to highlight the content of different sections.

Case reports should be prepared in a narrative style and comprise: (1) a short introduction stating the reasons for reporting the case; (2) the case report, including history, investigations and treatment; (3) a discussion referring to the relevant literature.

Letters to the Editor are afforded priority publication. They should be no longer than $\mathbf{2 0 0 0}$ words, with no more than six references, and will typically report work in progress. A full address is required for the corresponding author. All authors and their institutional affiliations should be given at the end of the letter.

\section{Measurements and abbreviations}

Measurements should be reported in SI units. Where non-SI units are in common use, for example blood pressure in $\mathrm{mmHg}$, SI units should be given in parentheses. Abbreviations must be defined at first mention in the text. Further details may be found in: Units, Symbols, and Abbreviations. A Guide for Medical and Scientific Editors and Authors. 


\section{Acknowledgements}

Only the help of those who have made substantial contributions to the study and/or the preparation of the paper should be acknowledged. The sources of financial support, or of donated equipment, must be acknowledged. Potential conflicts of interest should be disclosed to the Editor in the first instance.

\section{References}

Only essential references should be included and authors should verify them against the original source material. References should be identified in the text by superscript Arabic numerals, and numbered and listed at the end of the typescript in the order in which they are first cited in the text. Any sort of automatic numbering should be avoided.

All references should include the names and initials of all authors (unless there are more than six, in which case only the first three should be given, followed by et al.). Publications for which no author is apparent may be attributed to the organization from which they originate. Simply omit the name of the author for anonymous journal articles - avoid using 'Anonymous'. References to papers should include the title of the paper; the journal title in full; year of publication; volume number (and issue number in parenthesis if volumes are not numbered consecutively throughout); first and last page numbers. References to books and reports should give the title, place of publication, publisher and year. References to chapters in books and papers in conference proceedings should also include the chapter or paper title, page numbers and the names and initials of the editors, as well as the place of publication, publisher and year of publication. Punctuation in references should be kept to a minimum, as shown in the following examples:

1 Baron DN, ed. Units, Symbols, and Abbreviations. A Guide for Medical and Scientific Editors and Authors. 5th edn. London: Royal Society of Medicine, 1994 2 Tang P, Venables T. 'Smart' homes and telecare for independent living. Journal of Telemedicine and Telecare 2000; 6: 8-14 3 Meade MS. Implications of changing demographic structures for rural health services. In: Gesler WM, Ricketts TC, eds. Health in Rural North America. New Brunswick, NJ: Rutgers University Press, 1992: 69-85

Papers accepted for publication but not yet published should be included in the list of references, followed by '(in press)'. Papers in preparation, personal communications and unpublished observations, if essential to cite, may also be listed as references.

Material on Websites should be referenced using the following format:

4 http://www.rsmpress.co.uk/jtt.htm. Last checked 1 June 2004 


\section{Tables}

Tables should not duplicate information given in the text. The tables feature of the word processor should be used to prepare them. They should be numbered in the order in which they are referred to in the text and appear on separate pages at the end of the typescript. A brief title should be placed above each table. Vertical rules and/or background shading should not be used.

\section{Illustrations}

Illustrations (figures) should be numbered in the order in which they are mentioned in the text. A list of legends (one for each figure) should appear on a separate page at the end of the typescript. Separate files must be provided for the figures and printouts of these appended to the typescripts. All illustrations should be provided in camera-ready form. Charts (e.g. histograms and graphs) should be supplied as Excel spreadsheets (preferably one spreadsheet per chart). Other line figures (e.g. maps and flow charts) should be supplied in WMF format. Photographic images should be supplied in TIFF or JPEG format at a resolution of at least 300 dpi. Any lettering/numbering should be sufficiently large to ensure legibility after reduction for publication - i.e. to a width of $82 \mathrm{~mm}$ (single column) or $170 \mathrm{~mm}$ (page width). One set of black and white photographs should be supplied for any images on the disk that are not line 'drawings'. Illustrations may be altered or deleted at the Editor's discretion.

\section{Consent}

The consent of patients and approval of the protocol by an ethics committee should be confirmed for human investigations.

Where a patient might be identified via an illustration or from the text, it is essential that written permission is obtained from that patient and forwarded with the typescript.

Any statements which might be construed as being potentially defamatory must be avoided.

Original textual matter quoted from other authors must have formal citation and be appropriately referenced.

Any tables or illustrations previously published should be accompanied by the written consent of the copyright holder to replication, an acknowledgement included in the caption, and the full reference included in the list.

\section{Proofs and offprints}

Proofs will be sent to the author designated to receive them; corrections should be kept to a minimum.

Twenty-five offprints of each published article will be supplied free of charge and additional offprints may be ordered from the publisher at preferential rates when the proofs are corrected. 


\section{B. TESE DE DOUTORAMENTO}

\section{LISTA DE ABREVIATURAS E SINAIS}

\begin{tabular}{ll} 
ABC & Santo André / São Bernardo / São Caetano \\
CCITT & Comitê do Conselho Internacional de Telegrafia e Telefonia \\
cec & carcinoma espinocelular \\
CODEC & compactador / descompactador \\
CPU & unidade de processamento central \\
D & direito (a) \\
DMA & acesso direto à memória \\
DV & vídeo digital \\
DVD & vídeo disco digital \\
E & esquerdo (a) \\
et al. & e outros \\
exam. & examinador \\
EUA & Estados Unidos da América \\
FM & faculdade de medicina \\
GHx & giga Hertz \\
Hz & Hertz \\
ISDN & rede digital de serviços integrados \\
ITU & União Internacional de Telecomunicações \\
JPEG & grupo de especialistas em fotografia e gráficos \\
K & coeficiente Kappa \\
\hline
\end{tabular}




\begin{tabular}{|c|c|}
\hline kbps & quilo bits por segundo \\
\hline MB & mega bytes \\
\hline Mbps & mega bits por segundo \\
\hline $\mathrm{mm}$ & milímetro \\
\hline $\mathrm{ms}$ & milisegundos \\
\hline p. & página \\
\hline ppvv & pregas vocais \\
\hline pv & prega vocal \\
\hline RAM & memória de acesso aleatório \\
\hline rpm & rotações por minuto \\
\hline SVHS & super VHS \\
\hline TM & telemedicina \\
\hline TIP & Telemedicine Instrument Pack \\
\hline USP & Universidade de São Paulo \\
\hline v. & volume \\
\hline VC & videoconferência \\
\hline VHS & sistema de vídeo doméstico \\
\hline W & Watts \\
\hline WEB & world wide web \\
\hline ( & marcar registrada \\
\hline$\%$ & por cento \\
\hline$<$ & menor que \\
\hline
\end{tabular}




\section{RESUMO}

\section{LAZZARINI, C.L. Análise da confiabilidade do telediagnóstico por imagens dinâmicas em laringologia. São Paulo, 2004. Tese (Doutorado) - Faculdade de Medicina, Universidade de São Paulo.}

Este estudo visa estabelecer o nível de confiabiliadade diagnóstica que a transmissão de videolaringoscopias por videoconferência (VC) proporciona, avaliando a qualidade da imagem transmitida e seu impacto sobre 0 diagnóstico. Dois DVDs contendo 60 imagens de videolaringoscopias (30 fibroscopias e 30 telescopias), sendo 30 imagens originais e 30 transmitidas por VC, foram avaliados por 6 otorrinolaringologistas que responderam a um questionário sobre a qualidade da imagem (escores 0 a 3) e o diagnóstico da doença. Um terceiro DVD contendo 26 pares de imagens, sendo uma original e a outra VC ou ambas originais, também foi analisado pelos examinadores, sendo questionado qual das duas imagens apresentava melhor qualidade, qual era a de VC e se a diferença de qualidade entre ambas afetava 0 diagnóstico. Houve alta concordância entre os examinadores $(K=0,911)$ sobre qual era a imagem de $\mathrm{VC}(96,15 \%$ de acerto) e de que a imagem original era a de melhor qualidade $(K=0,850)$. Embora houvesse concordância parcial entre os examinadores $(K=0,371)$, a qualidade da imagem da VC não comprometeu o diagnóstico em 75,64\% dos casos. A imagem de melhor qualidade foi a de videotelescopia original $(83,33 \%$ ótimas) e a pior a de videofibroscopia por VC (36,66 \% ótimas ou boas). Houve elevado índice de acertos diagnósticos nas imagens de VC (86,67\% nas fibroscopias e nas telescopias). Deste modo a utilização da VC para a transmissão de imagens de videolaringoscopias provou ser eficaz para o diagnóstico remoto de doenças de laringe. 


\section{SUMMARY}

\section{LAZZARINI, C.L. Reliability analyses for telediagnosis by dynamic image}

in laryngology. São Paulo, 2004. Tese (Doutorado) - Faculdade de Medicina, Universidade de São Paulo

The present study aims to establish the level of diagnostic reliability provided by the transmission of a videolaryngoscopy by videoconference (VC), evaluating the quality of the transmitted images and its impact on diagnoses. Two DVDs with 60 laryngoscopy (30 fiberscopies and 30 telescopies) images, corresponding to 30 original and 30 transmitted by VC, were evaluated by 6 laryngologists who answered a questionnaire on the quality of the selected images (scores from 0 to 3 ) and on the diagnoses of the related disease. A third DVD with 26 pairs of images, an original and a VC, or two original, was also analyzed by the examiners who had to select which image presented the best quality, which corresponded to the VC image, and the possible impact of such differences on the quality of diagnoses. A high level of agreement $(K=0.911)$ was found among the examiners in relation to the identification of the VC $(96,15 \%$ of accuracy) and to the best quality of the original image $(K=0,850)$. Although a partial agreement has been found among the examiners $(K=0,371)$, diagnoses was not jeopardized by the quality of the VC image in $75,64 \%$ of the cases. Original videotelescopy images $(83,33 \%$ very good) showed the best quality and videofiberscopy VC the worst (36,66\% very good and good). A high degree of correctness was found for the diagnoses by VC images $(86,67 \%$ by fiberscopy and by telescopy). Consequently, the use of a VC to transmit videolaryngoscopy images has proved to be efficient for the remote diagnoses of larynx diseases. 


\section{INTRODUÇÃO}

Segundo definição da NATIONAL LIBRARY OF MEDICINE (1993), telemedicina (TM) é a entrega de serviços médicos via telecomunicações remotas, o que inclui consulta interativa e serviços diagnósticos. Como o uso das tecnologias de telecomunicação para a interação entre profissionais de saúde e pacientes, com a finalidade de realizar ações médicas à distância, a TM vem se tornando realidade (SABBATINI, 2000).

Pode-se transmitir fotografias, vídeos, dados e sons, sendo utilizada na educação, diagnóstico e segunda opinião médica em todo o mundo, alterando a maneira como a medicina, incluindo-se a otorrinolaringologia, vem sendo praticada (RINDE et al., 1993) .

A TM não é nova. De uma maneira geral foi iniciada nos anos 20 , quando médicos utilizaram comunicação de rádio entre um navio e a costa para orientar aqueles que estavam no mar (WINTERS, 1921). Nos anos 30 foram realizadas transmissões de eletrocardiogramas (CHOUINARD, 1983) e em 1950 dois médicos da Filadélfia descreveram a transmissão de um facsímile de teleradiologia por telefone (GERSHON-COHEN; COLEY 1950). Em 1959, o Instituto Psiquiátrico de Nebrasca utilizou televisão interativa 
para educação de estudantes de medicina através do campus da universidade (WITTSON; BENSCHOTER, 1972). BIRD (1972) descreveu o primeiro sistema compreensivo de TM instalado em 1967 entre a estação médica do aeroporto Logan em Boston e o Hospital Geral de Massachussets.

A TM da maneira como a vemos hoje teve um grande impulso quando, nos anos 70, foram lançados, pelo governo dos EUA e Canadá, satélites de comunicação, proporcionando as primeiras oportunidades para experimentos de TM de longo alcance (MOORE, 1999).

Em 1978 foram conectados 38 hospitais nos EUA através de satélites de comunicação, proporcionando consultas remotas e educação continuada a médicos e pacientes (VA SATELLITE EDUCATION PROJECT, 1978).

O alto custo da tecnologia disponível nos anos 80 foi o principal responsável pela falta de continuidade dos estudos neste período (BLAKESLEE et al., 1998).

O período de rápido desenvolvimento da TM iniciou-se no final da década de 80 e início da década de 90 devido a melhorias nas tecnologias e infraestrutura de comunicação, seu barateamento, assim como maior interesse governamental sobre o assunto (MOORE, 1999).

A TM pode ser síncrona (vídeoteleconferência em tempo real - VC) ou assíncrona ("store-and-forward"). No formato VC o profissional que consulta o paciente e o que solicitou a avaliação vêem o paciente ao mesmo tempo e é utilizado em especialidades que requerem um diálogo ou interação significante entre médico e paciente em tempo real, por exemplo 
em psiquiatria e cuidados intensivos (HOLTEL; BURGESS, 2002). É tecnicamente mais complexa e depende de um agendamento prévio de ambas as partes. Estas consultas podem ser realizadas com o paciente acompanhado por um técnico ou um médico generalista treinados para os procedimentos básicos (HENEGHAN et al., 1999). O formato assíncrono é mais utilizado em especialidades onde o diagnóstico visual é importante, tais como patologia, dermatologia e radiologia. Nesta modalidade o médico examinante coleta todas as informações necessárias, as envia ao especialista, e aguarda uma resposta (ALLELY, 1995). Na TM atual, vários autores descreveram o declínio do vídeo interativo e o florescimento das tecnologias de TM do tipo assíncrono (PERENDIA, 1996, DAKINS, 1998, GRIGSBY; SANDERS, 1998, WHEELER, 1998). Estes métodos, que se utilizam também da Internet e aplicações baseadas na WEB, se mostraram melhores economicamente e mais disponíveis universalmente, resultando em economia de tempo nas consultas em relação aos métodos síncronos.

As redes atuais de TM podem também ser utilizadas para educação, banco de dados de decisões clínicas, inteligência artificial, prontuário médico e suporte administrativo. Por este motivo o termo telesaúde é muitas vezes utilizado para descrever o conjunto completo de tecnologias, redes e serviços de saúde providos de telecomunicações (MOORE, 1999).

ULOZA et al.,(2003) definiram a tele-otorrinolaringologia como o uso de imagens, voz e outros dados transmitidos para permitir consulta, pesquisa e coleta de dados experimentais; criação de bases de dados e educação e integração em otorrinolaringologia através da distância. 
O uso da telemedicina para avaliação de pacientes por um especialista em otorrinolaringologia é uma grande oportunidade para se modificar o modo como pacientes são encaminhados de lugares remotos (GOLDENBERG; WENIG, 2002).

As tecnologias atuais permitem apenas a transmissão de informações visuais e auditivas, perdendo-se as capacidades olfativas e tácteis (SCLAFANI et al., 1999). A otorrinolaringologia é uma área de grande potencial para as aplicações de TM, pois utiliza no diagnóstico e na cirurgia imagens de videoendoscópicos (PEDERSEN et al., 1994). Por outro lado, a qualidade das imagens transmitidas pode ser um obstáculo ao desenvolvimento da TM.

Vários aspectos da TM em otorrinolaringologia foram estudados. Aspectos clínicos, terapêuticos e diagnósticos (STERN et al., 1998, SCLAFANI et al., 1999, BURGESS et al., 1999, BLAKESLEE et al., 1999, ULLAH et al., 2002); aspectos econômicos e sociais (BERGMO, 1997, AAS et al., 2001, FORTIN et al., 2003); aspectos cirúrgicos (BURGESS et al., 2002); aspectos educacionais (HENEGHAN et al., 1999, BURGESS et al., 2002) e de relacionamento médico-paciente (PEDERSEN; HOLAND, 1995). Todos as conclusões dos estudos incentivam a continuidade das pesquisas pelos bons resultados obtidos. $O$ fato das imagens poderem ser facilmente transmitidas para instituições remotas é útil e tem diferentes aplicações práticas (FURUKAWA et al., 1998). Especialmente na laringologia, onde o diagnóstico depende da avaliação detalhada de imagens extremamente 
dinâmicas, a resolução da imagem transmitida pode inviabilizar seu emprego.

Por outro lado, se a qualidade das imagens transmitidas for similar às obtidas originalmente, estarão abertas as portas para que em tempo real, por VC efetiva, sejam visualizadas as imagens pelo assistente remoto ao mesmo tempo em que o exame é realizado por um assistente local, permitindo inclusive interação com o paciente em questão ou com o assistente local, modificando em tempo real as prioridades no exame. 


\subsection{Objetivos}

Frente à escassez de estudos atuais na transmissão de imagens de videolaringoscopia para diagnóstico remoto por VC, temos como objetivo comparar imagens originais de videolaringoscopias dinâmicas com a obtida após transmissão por VC nos seguintes aspectos:

1. Avaliar se é possível diferenciar uma imagem original de uma imagem transmitida por VC

2. Avaliar a qualidade das imagens de telescopias e fibroscopias antes e depois da transmissão por VC.

3. Se existir diferença entre as imagens, se ela interfere na qualidade diagnóstica.

4. Avaliar se as imagens transmitidas por VC permitem um diagnóstico adequado, diferenciando-se fibroscopias e telescopias. 


\section{REVISÃO DA LITERATURA}

Por ser uma tecnologia relativamente nova, a literatura sobre VC em otorrinolaringologia ainda é escassa, especialmente se levarmos em consideração estudos específicos em laringologia. Revimos então os principais aspectos da TM na especialidade, com ênfase maior em estudos referentes à laringe.

Verificamos que a maioria dos estudos ocorre na década de 90 com o ressurgimento do interesse pelo uso da TM devido ao desenvolvimento de novas técnicas de telecomunicações e aplicações da Internet. Adiciona-se a isso a progressiva redução no custo dos equipamentos utilizados para a captura e transmissão de dados médicos (BLAKESLEE et al., 1998, MOORE, 1999).

A nasofaringolaringoscopia é comumente utilizada em pacientes com sintomas diversos como disfagia, tosse e para investigação de lesões nasais, de faringe ou laringe (DEWITT, 1988). Sua utilização é limitada, porém, a pacientes próximos a centros com especialistas para conduzir e interpretar o exame. HENEGHAN et al. (1999) sugeriram que o exame possa ser realizado, após treinamento, por qualquer médico, enfermeiro ou técnico 
de saúde e portanto ser enviado via TM para locais onde o especialista conduzirá o caso.

PEDERSEN et al. (1994) realizaram um estudo pioneiro que integrou equipamentos endoscópicos com VC para estabelecer diagnósticos remotos em pacientes com afecções otorrinolaringológicas. $\mathrm{O}$ estudo foi realizado na Noruega motivado pela necessidade de reduzir custos e assegurar bons serviços de saúde à população, já que esta é uma comunidade dispersa por longas distâncias, muitas vezes dependente de barcos e helicópteros para locomoção entre as inúmeras ilhas da região. Utilizaram endoscópicos rígidos (otoscópio de 0 graus, endoscópio de 30 graus para exame da cavidade nasal, endoscópio de 110 graus para rinoscopia posterior e de 90 graus para laringoscopia). O estúdio de transmissão foi equipado com uma câmera de resolução de 410 por 410 linhas e um monitor Sony de resolução de 600 por 575. A transmissão das imagens foi realizada com uma conexão de 2 Mbps. Durante a primeira fase um médico generalista foi instruído a utilizar os equipamentos endoscópicos em exames otorrinolaringológicos (30 pacientes). Numa segunda fase, o generalista encontrava-se realizando o exame em uma sala e um especialista em outra sala, transmitindo os sinais em paralelo através de um software de compactação (CODEC). Isto significava que a imagem recebida pelo especialista tinha a mesma qualidade da imagem transmitida a 2 Mbps. Logo após a transmissão o especialista se dirigia para a sala ao lado para realizar um exame usual no paciente para comparação. Durante a segunda fase (17 pacientes) a correspondência diagnóstica entre o exame pela simulação de VC e o 
exame no local foi de $100 \%$, permitindo que 8 pacientes fossem tratados somente pelo generalista através de exame endoscópico transmitido por VC. $\mathrm{Na}$ terceira fase o exame foi transmitido em tempo real a um especialista a 180 milhas de distância. Cinco de 7 pacientes desta fase puderam ser tratados pelo generalista sozinho. O autor conclui mostrando que este método de consulta pode ser utilizado na clínica com o mesmo grau de reprodutibilidade de uma consulta tradicional, permitindo um tratamento do paciente em locais remotos e a custos menores.

Como um desdobramento deste estudo, PEDERSEN; HOLAND (1995) realizaram novo trabalho medindo o grau de satisfação do paciente com relação a este novo procedimento diagnóstico. Após preenchimento de questionários por 24 pacientes examinados por tele-endoscopia, 23 estavam satisfeitos com o novo tipo de consulta e relataram mais vantagens que desvantagens, justificando a realização de novas investigações sobre esta e novas formas de consultas por TM na especialidade.

CRUMP; DRISCOLL (1996) utilizaram um kit de instrumentais para TM denominado TIP (TM Instrument Pack), um pequeno pacote de instrumentais produzidos pela NASA para exames otorrinolaringológicos via TM contendo um nasofaringolaringoscópio, lentes, câmera de vídeo, um monitor e uma fonte de luz halógena. O equipamento foi considerado adequado para exame da rinofaringe, hipofaringe e laringe. Foi concluído que exames da orelha e orofaringe não foram satisfatórios e sugeridas algumas mudanças no protótipo. 
BERGMO (1997), realizou análise econômica da teleconsulta em ORL. Foi realizado uma comparação de três diferentes métodos de consulta: teleconsulta, chamada de um especialista e translado do paciente para o centro de cuidados secundário mais próximo. Concluiu que a teleconsulta teve uma boa relação custo-benefício quando o número de procedimentos fosse maior que 52 por ano. Ainda quanto ao aspecto econômico, FORTIN et al. (2003) concluiram em estudo sobre aplicações de VC em várias especialidades, incluindo a otorrinolaringologia, que 8 transferências de emergência e 15 pacientes que necessitariam transferência eletiva foram conduzidos localmente por um clínico utilizando-se técnicas de TM (total de 101 casos estudados).

VIRRE et al. (1997) mostraram a viabilidade de uma consulta remota em uma reunião de grupo de pacientes veriginosos. Foi utilizado um equipamento bidirecional de áudio e vídeo e transmitido, via VC, história do paciente, exame físico e eletronistagmografia. Foram realizados o diagnóstico e tratamento sob a supervisão de um especialista remoto.

DUFFY et al. (1997) e BURGESS et al. (1999) estudaram a utilização da VC em distúrbios da fala. O primeiro concluiu a viabilidade do procedimento desde que a transmissão audiovisual tenha qualidade suficiente para permitir uma interpretação confiável dos sinais e sintomas. Utilizou um ambiente de VC que permitiu que o terapêuta remoto e o paciente vissem imagens um do outro, seja em corpo inteiro ou closes dos lábios, língua e pálato. O segundo comparou a utilização de VC com sessões presenciais. Os resultados mostraram melhora em todos os casos 
tratados por desordens de fala via VC, com avaliação positiva dos pacientes..

FURUKAWA et al. (1998) realizou estudo retrospectivo para avaliar a utilidade da transmissão de imagens laríngeas estáticas em 29 pacientes com sintomas vocais. Duas imagens de laringe foram capturadas por um generalista utilizando-se um telescópio de laringe equipado com uma câmera de vídeo. Uma imagem foi capturada durante o repouso vocal e outra durante a fonação. As imagens foram impressas, digitalizadas por um escaner e transmitidas, juntamente com dados de história, como anexos de e-mail no formato JPEG na resolução máxima. Os diagnósticos foram feitos por três especialistas que receberam os arquivos de imagem e texto. Foram idênticos aos diagnósticos realizados pelo especialista que enviou os arquivos. $\mathrm{O}$ autor sugere que os distúrbios de motricidade da laringe podem ser inferidos comparando-se as imagens durante o repouso vocal (respiração) e durante a fonação. Concluiu que o sistema de transmissão de imagens é uma ferramenta útil na consulta entre otorrinolaringologistas e entre médicos generalistas e especialistas, embora o generalista apresentasse dificuldade em capturar as fases exatas da movimentação laríngea.

HOLTAN (1998) realizou estudo sociológico preocupando-se com a maneira com que os métodos de TM por transmissão em tempo real na otorrinolaringologia interfeririam na relação médico-paciente. Foram realizados em 17 pacientes anamnese e exame endoscópico por um médico generalista e transmitidos por VC a um otorrinolaringologista em tempo real. 
Concluiu que, embora a VC aparentemente restrinjisse o contato pessoal com o especialista, na verdade representou um sistema de interação mais amplo para acesso, inspeção e informação, fornecendo aos pacientes várias maneiras de participar da consulta. Este fato foi considerado positivo pela maioria dos pacientes.

BLAKESLEE et al (1998) realizaram estudo prospectivo para demonstrar a utilidade de três sistemas de TM na prática otorrinolaringológica (OPTEL, GSTP e PICASSO). Constataram que as principais dificuldades na prática da TM são devidas a fatores como: credenciamento, direitos à privacidade, responsabilidade por mal-prática, desenho do sistema, infraestrutura e reembolso. As vantagens seriam: melhora no acesso a consultas de especialistas a partir de um hospital rural, melhora na troca de informações entre médicos, melhora na relação médicopaciente, melhora no controle evolutivo, maior permanência dos pacientes dentro da comunidade e menores custos indiretos ao médico e paciente.

SCLAFANI et al (1999) estudaram as vantagens e desvantagens das modalidades de TM síncrona (em tempo real) e assíncrona ("store-andforward") em avaliações otorrinolaringológicas. Compararam consultas e exames nasofaringolaringoscópicos realizados localmente com consultas acompanhadas por um otorrinolaringologista localizado remotamente em tempo real por uma conexão ISDN de $384 \mathrm{kbps}$. Depois um terceiro otorrinolaringologista fez a revisão do exame via VC. Todos os três médicos documentaram seus achados, mostrando que o otorrinolaringologista local e o remoto que fez os diagnósticos em tempo real chegaram ao mesmo 
diagnóstico em $85 \%$ dos casos. O otorrinolaringologista local e o remoto que viu os achados posteriormente, chegaram a um mesmo resultado em $64 \%$ dos casos. $\mathrm{O}$ autor concluiu que ambas modalidades podem ser utilizadas para obtenção de uma eficácia clinica razoável no diagnóstico em otorrinolaringologia. STERN et al.(1998) em estudo semelhante anterior haviam chegado aos mesmos resultados e concluído que o método assíncrono, apesar de fornecer dados valiosos em imagens capturadas de exames nasofaringolaringoscópicos inclui menos informações, além de não oferecer retorno imediato.

MADE et al. (1999), conectaram dois centros de saúde primários, um na comunidade rural da Noruega e outro no Hospital Universitário de UMEA na Suécia, por uma conexão ISDN de 384 kbps. Ambos centros estavam equipados com vídeo-endoscópios. Durante 21 meses, foram realizadas 32 consultas otorrinolaringológicas com duração de 15 a 30 minutos cada. Pacientes, médicos generalistas e especialistas foram submetidos a um questionário. A satisfação do paciente com a metodologia da consulta foi de 5,7 de um máximo de 6 . Os especialistas julgaram a VC satisfatória para diagnóstico e concluíram que $40 \%$ dos encaminhamentos poderiam ter sido evitados pelo uso da TM.

Estudos utilizando-se vídeo-otoscópios e transmissão das imagens por VC na otologia foram realizados por BURGESS et al. (1999), HENEGHAN et al. (1999), EIKELBOOM et al. (2002) e PATRICOSKI et al. (2003) todos mostrando alto grau de correlação entre consultas locais e remotas. 
SYMS; SYMS III (2001) e FRIED (2001) preconizaram que mudanças nos sistemas de reembolso de procedimentos realizados por TM serão os catalisadores para acelerar a integração da TM à prática diária em otorrinolaringologia e cirurgia de cabeça e pescoço em um futuro muito próximo.

ULLA et al. (2002) estudaram o valor da VC em tempo real usando equipamentos de baixo custo para consultas otorrinolaringológicas. No estudo um médico generalista apresentou pacientes a um otorrinolaringologista remoto e um diagnóstico era firmado e, se necessário, exames subsidiários eram solicitados. Os pacientes foram vistos pelo mesmo otorrinolaringologista para uma consulta tradicional. Não houve dificuldade na obtenção da história e solicitação de exames via TM. O exame físico foi considerado inadequado em 8 dos primeiros 20 pacientes. Nos últimos 22 houve correto diagnóstico e plano de tratamento. Foi atribuído o maior erro inicial à inexperiência no uso do equipamento pelo generalista, o que foi corrigido nos últimos casos. Os autores concluem que o uso de TM de baixo custo é uma técnica útil promovendo consultas satisfatórias na especialidade em um ambiente de prática médica generalista, porém um treinamento inicial adequado deve ser realizado.

Quanto aos estudos de telecirurgia em otorrinolaringologia, em geral estão na mesma posição de 10 a 15 anos atrás (GOLDENBERG; WENIG, 2002). Embora existam grandes possibilidades de desenvolvimento técnico, também existem importantes barreiras. BOWERSOX (1998) distribuiu um questionário a 141 cirurgiões chefes na Suíça para avaliar seus 
conhecimentos e aceitação da TM na cirurgia. Embora 93\% dos departamentos cirúrgicos utilizassem tecnologia de informática e $85 \%$ utilizassem regularmente a Internet, apenas $8 \%$ utilizavam a TM. A maioria dos cirurgiões ainda interroga o princípio de fazer e receber diagnósticos remotos via aplicações de TM.

A telemonitorização remota durante cirurgias foi o aspecto estudado por BURGESS et al. (2002) que conduziram um estudo prospectivo onde um grupo de residentes realizava cirurgias endoscópicas com um especialista na sala de cirurgia e outro grupo onde os residentes eram orientados por um especialista remoto via VC. Neste estudo com 72 pacientes, não houve diferença significativa de resultados entre os dois grupos. Além disso um benefício adicional foi encontrado no que se refere à educação dos residentes. Quando o residente foi bem orientado, mesmo sem a presença física do supervisor, seu aprendizado foi considerado melhor.

GOLDENBERG; WENIG (2002) realizaram revisão de literatura e discutiu o uso globalizado da TM na otorrinolaringologia. Mostrou 3 principais benefícios: reduzir morbidade, mortalidade e custos médicos pela detecção precoce de doenças mais graves (exemplo: tumores de cabeça e pescoço.); reduzir encaminhamentos desnecessários ao especialista com economia para o paciente e utilização mais eficiente do tempo do especialista. Por outo lado, relatou a falta de uma política definida para reembolso nas teleconsultas; aceitação lenta do uso das aplicações da TM pelos médicos especialistas e pelos generalistas rurais por desconforto com a tecnologia; relutância em mudar seus padrões de prática usuais e a preferência de 
transferir pacientes doentes ao invés de continuar tratando-os com a ajuda de um especialista remoto. Cita também que a segurança com a confidencialidade dos dados vem se tornando uma preocupação crescente e o uso da encriptação de dados por algumas redes torna-se a solução ideal para estes problemas. Outro fator de destaque são os custos dos equipamentos para VC que, embora continuem diminuindo, ainda são um problema a ser considerado (HOLTEL; BURGESS, 2002). 


\section{MATERIAL E MÉTODOS}

Este estudo foi aprovado pela Comissão de Ética para Análise de Projetos de Pesquisa do Hospital das Clínicas da Faculdade de Medicina da Universidade de São Paulo e realizado em obediência às normas éticas da Instituição.

\subsection{Seleção das imagens}

Foram estudadas 60 imagens de videolaringoscopias (30 telescopias e 30 fibroscopias) selecionadas a partir de exames realizados nas Faculdades de Medicina do ABC (42 imagens) e da USP (18 imagens).

Para seleção das primeiras 42 imagens da foram analisadas 190 videolaringoscopias arquivadas no formato VHS no acervo do Departamento de Otorrinolaringologia da Faculdade de Medicina do ABC, sendo 115 telescopias (KARL STORZ Modelo 8706CJ de 70 graus) e 85 endoscopias com fibra flexível (PENTAX Modelo FNL-10RP3 de $3.2 \mathrm{~mm}$ de diâmetro)(Figuras 1 e 2). Todas as imagens foram gravadas de pacientes com queixas laríngeas e tiveram seu diagnóstico firmado na Reunião do Grupo de Laringologia da Instituição nos anos de 2001 a 2003. As imagens foram obtidas por uma microcâmera TOSHIBA, modelo IK-CU43A, com 
fonte de luz halógena FACTORY de $250 \mathrm{~W}$ de potência (Figuras 3 e 4) e gravadas no formato VHS, por um Vídeocassete SEMP Modelo X687 (Figura 5)

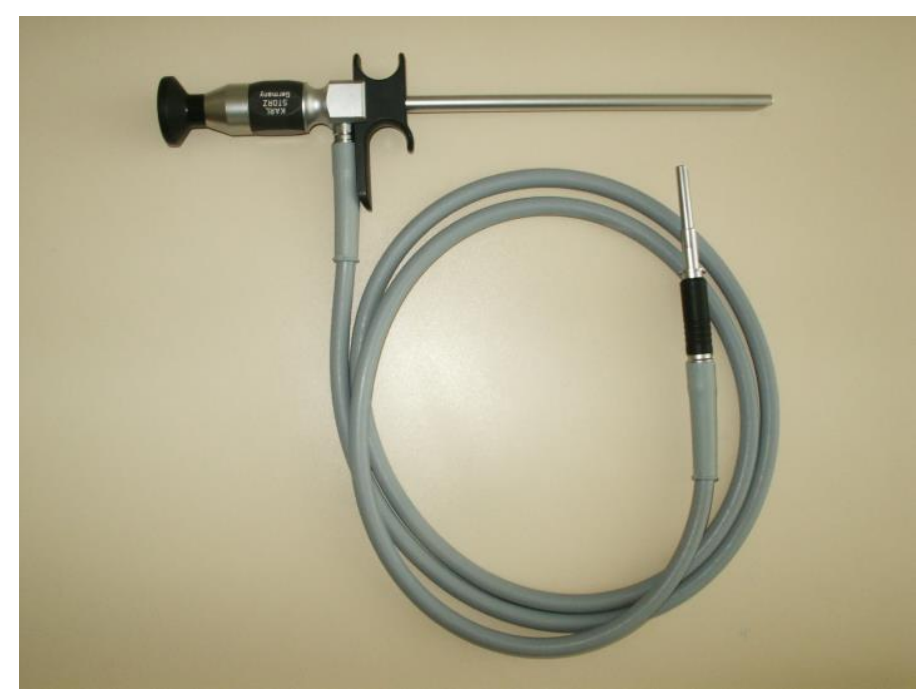

FIGURA 1: TELESCÓPIO DE LARINGE KARL STORZ MODELO 8706CJ

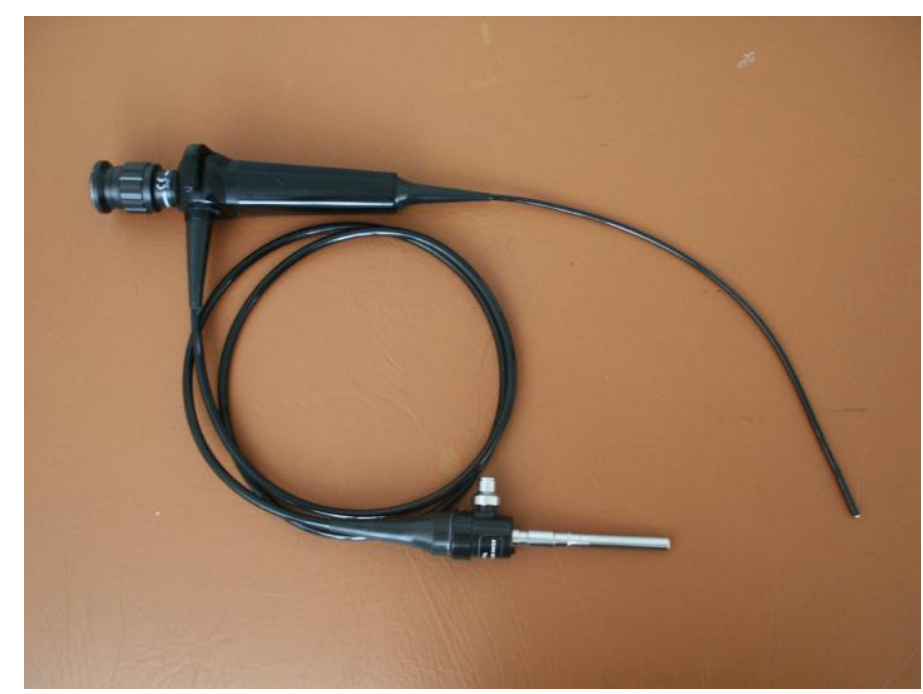

FIGURA 2: NASOFIBROSCÓPIO PENTAX MODELO FNL-10RP3 


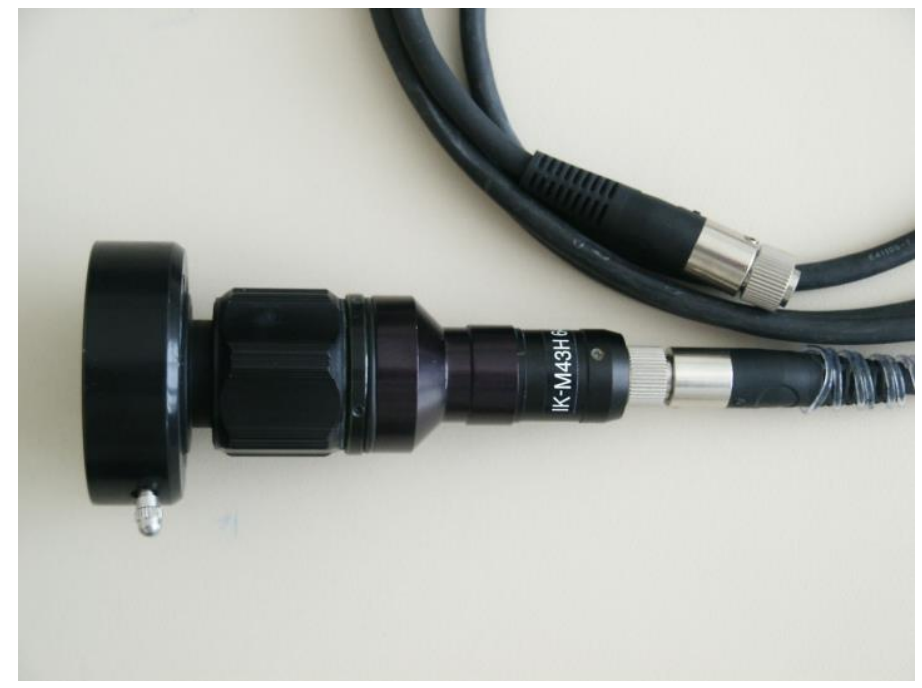

FIGURA 3: MICROCÂMERA TOSHIBA MODELO IK-CU43A

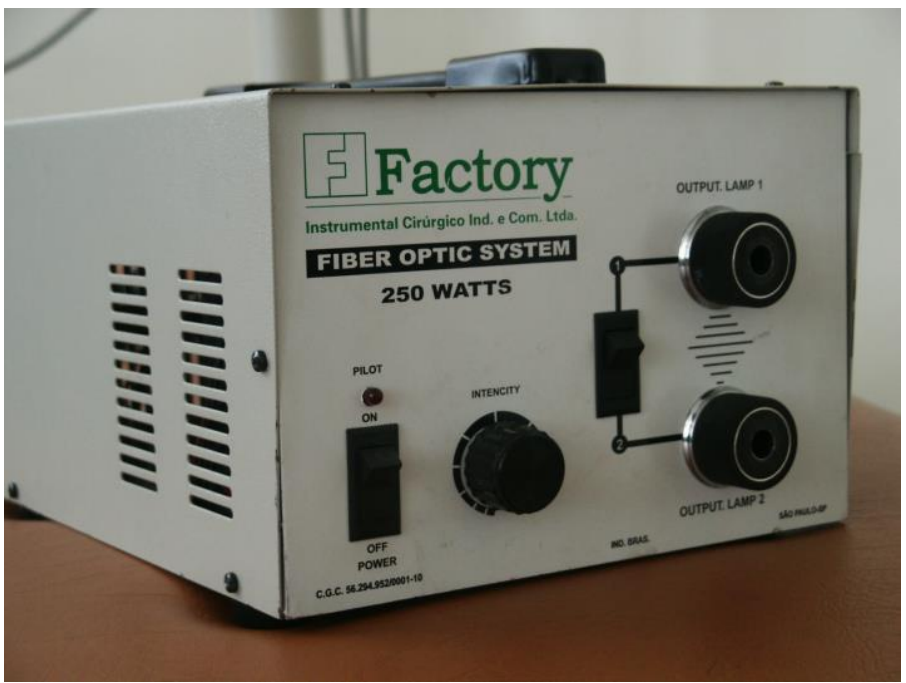

FIGURA 4: FONTE DE LUZ FACTORY DE $250 \mathrm{~W}$ 


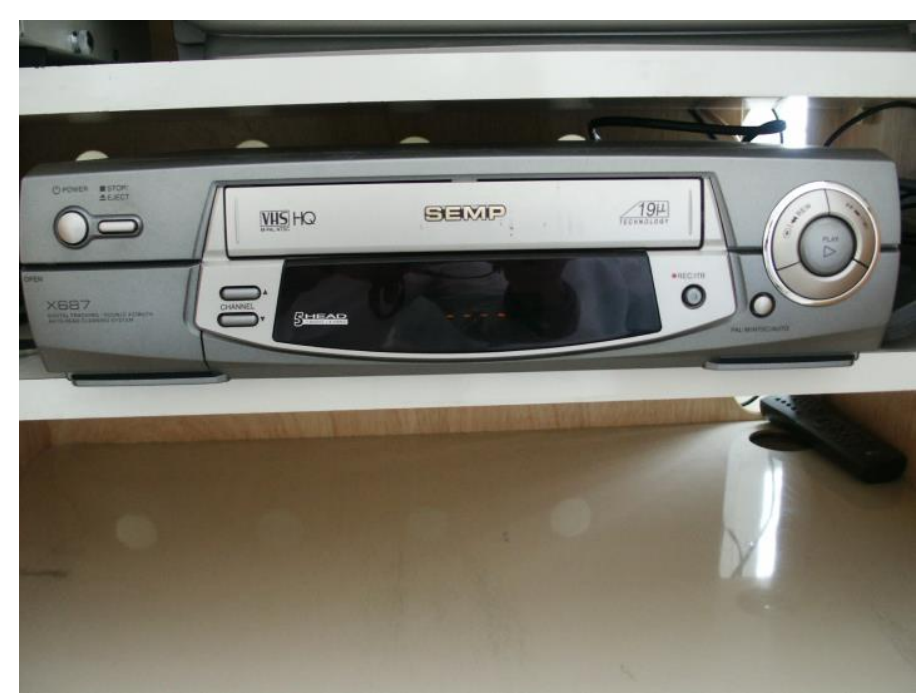

FIGURA 5: VÍDEOCASSETE RECORDER SEMP MODELO X687

Para seleção das outras 18 imagens foram analisadas 120 videolaringoscopias arquivadas no formato VHS no acervo do Serviço de Bucofaringolaringologia do Hospital das Clínicas da Faculdade de Medicina da USP, sendo 78 telescopias (KARL STORZ Modelo 8706CJ de 70 graus) e 42 endoscopias com fibra flexível (OLYMPUS ENF Type 10) (Figuras 6 e 7). Todas as imagens foram gravadas de pacientes com queixas laríngeas e tiveram seu diagnóstico firmado na Reunião do Grupo de Laringologia da Instituição nos anos de 2002 e 2003. As imagens foram obtidas por uma microcâmera ECOCAM-V, com fonte de luz halógena DOCMED modelo Doc Lux de 250 W de potência (Figuras 8 e 9) e gravadas no formato VHS, por um Vídeocassete SEMP TOSHIBA Modelo X688 (Figura 10). 


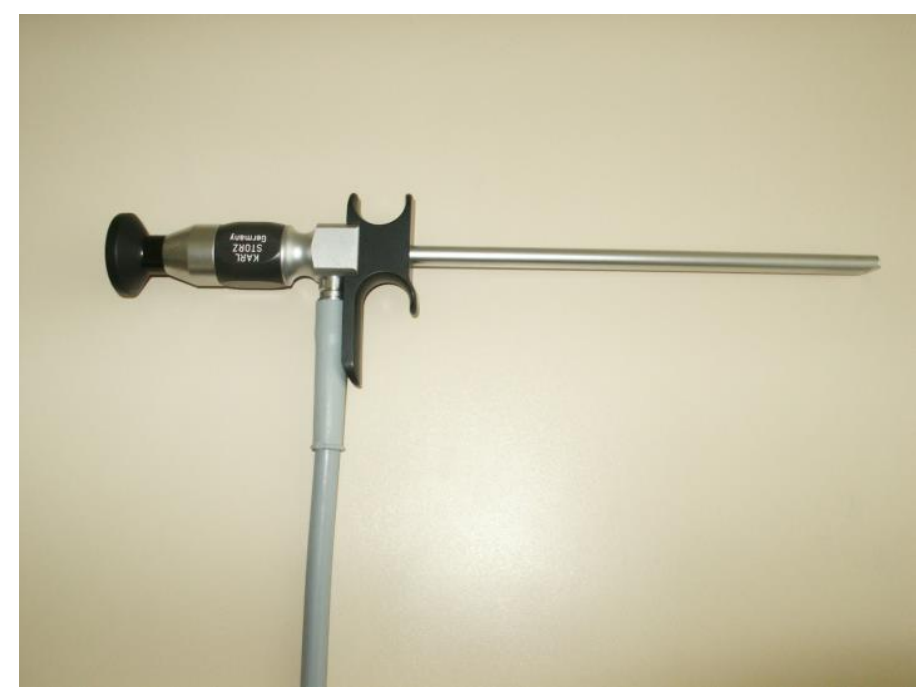

FIGURA 6: TELESCÓPIO DE LARINGE KARL STORZ MODELO 8706CJ

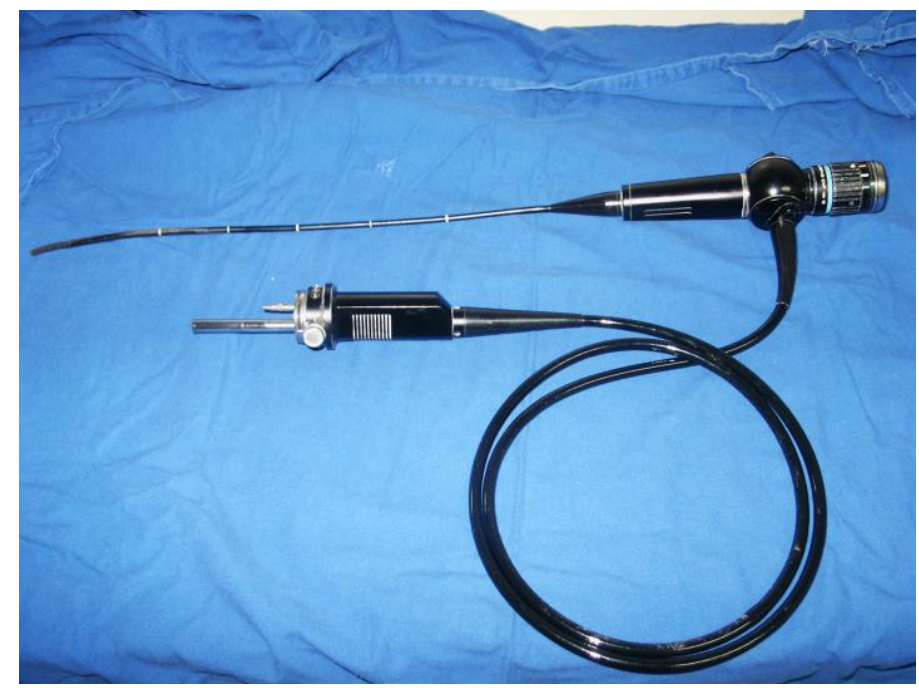

FIGURA 7: NASOFIBROSCÓPIO OLYMPUS MODELO ENF TYPE10 


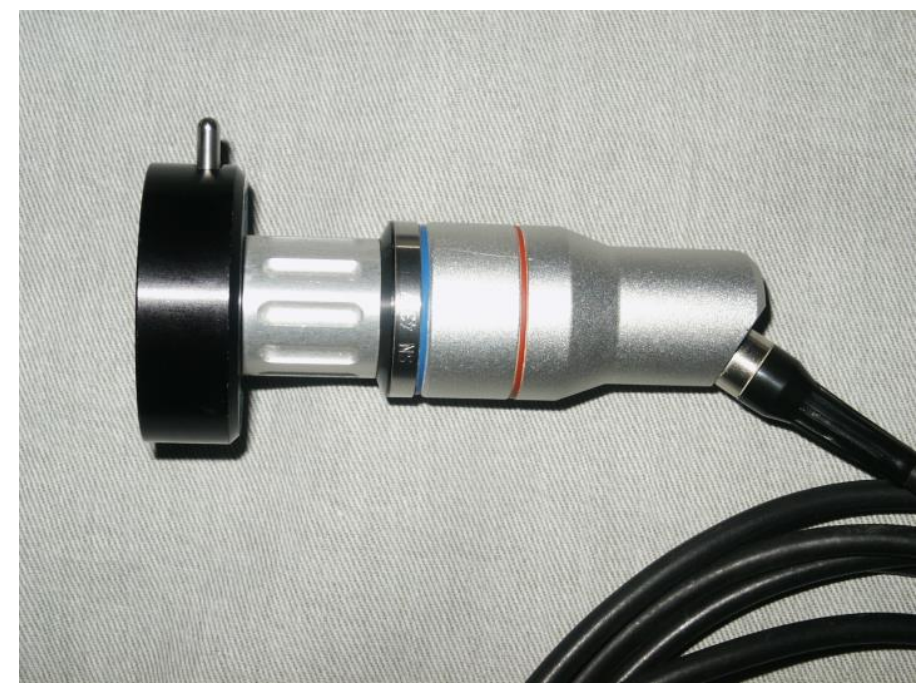

FIGURA 8: MICROCÂMERA ECOCAM-V

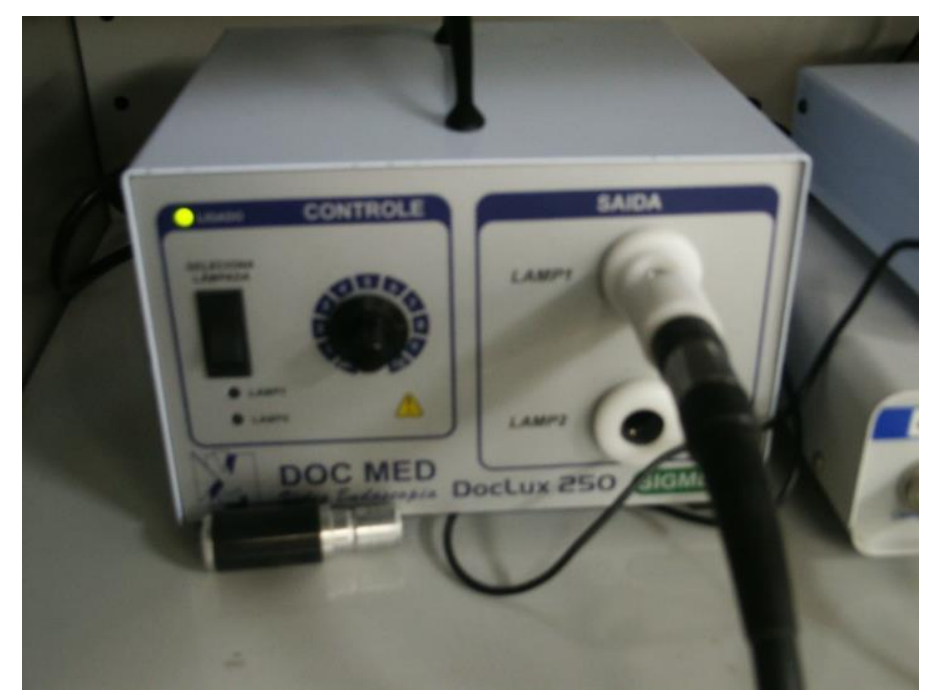

FIGURA 9: FONTE DE LUZ DOCMED MODELO DOCLUX 250 


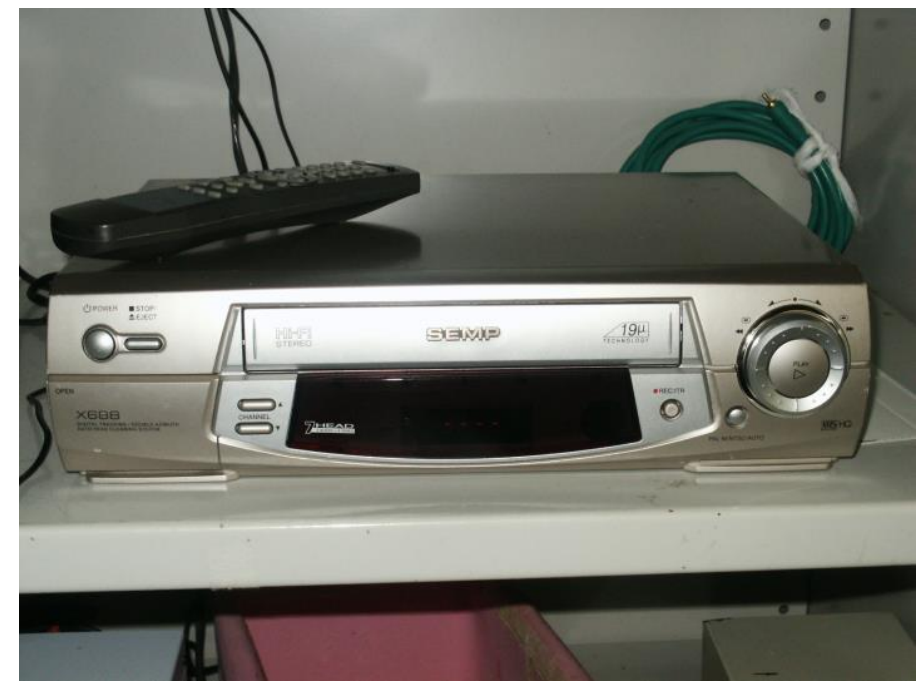

FIGURA 10: VIDEOCASSETE SEMP MODELO X688

$\mathrm{Na}$ escolha das imagens alguns aspectos foram considerados de maneira a se manter uma distribuição equilibrada (Tabela 1) entre:

1- Diagnósticos das lesões

2- Exames de fibroscopias ou telescopias

3- Qualidade da imagem

Foram excluídas imagens cujo diagnóstico era dúbio segundo as reuniões do grupo de laringologia.

TABELA 1 - DIAGNÓSTICO DAS IMAGENS ESCOLHIDAS PARA O ESTUDO

\begin{tabular}{cccc}
\hline diagnósticos & total & fibroscopias & telescopias \\
\hline carcinoma & 5 & 3 & 2 \\
papiloma & 5 & 2 & 3 \\
paralisia & 5 & 2 & 3 \\
cisto & 6 & 2 & 4 \\
pólipo & 6 & 3 & 3 \\
leucoplasia & 5 & 2 & 3 \\
nódulos & 5 & 4 & 1 \\
normal & 5 & 3 & 2 \\
edema de Reinke & 4 & 3 & 1 \\
sulco/fenda/vd ${ }^{*}$ & 8 & 2 & 6 \\
outros & 6 & 4 & 2 \\
\hline
\end{tabular}

${ }^{*} \mathrm{vd}=$ vasculodisgenesias 


\subsection{Digitalização das imagens}

As imagens selecionadas foram reproduzidas por um videocassete SEMP TOSHIBA modelo X688 (Figura 11) e gravadas em uma câmera de vídeo digital SONY Modelo TRV340 ${ }^{\circledR}$ (Figura 12) em duas fitas de vídeo SONY padrão Digital $8^{\circledR}$ (Figura 13) através de um cabo de vídeo padrão RCA (Figura 14).

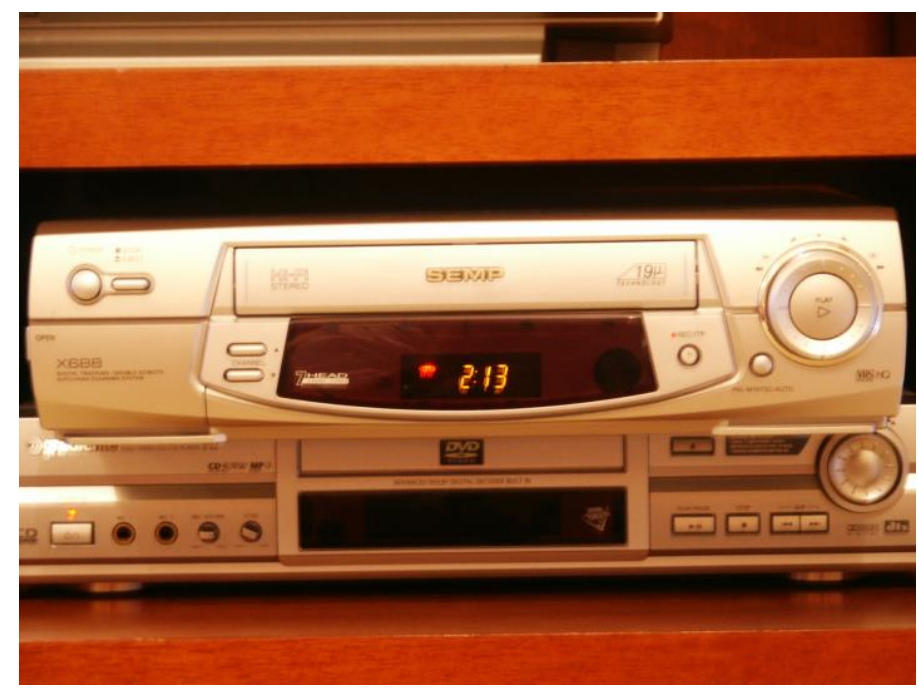

FIGURA 11: VIDEOCASSETE RECORDER TOSHIBA X688

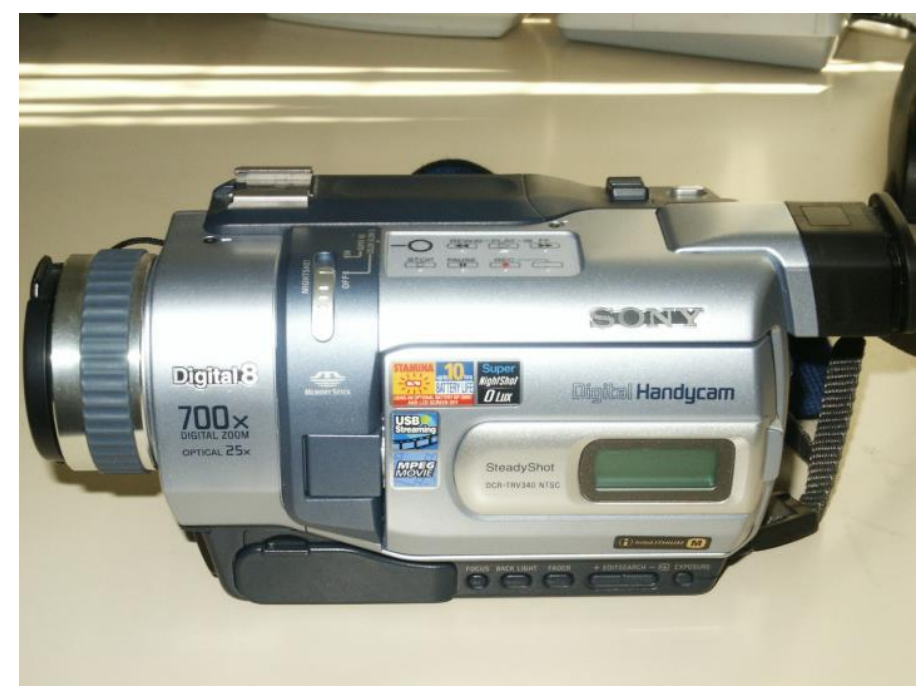

FIGURA 12: CÂMERA DE VÍDEO SONY TRV-340 


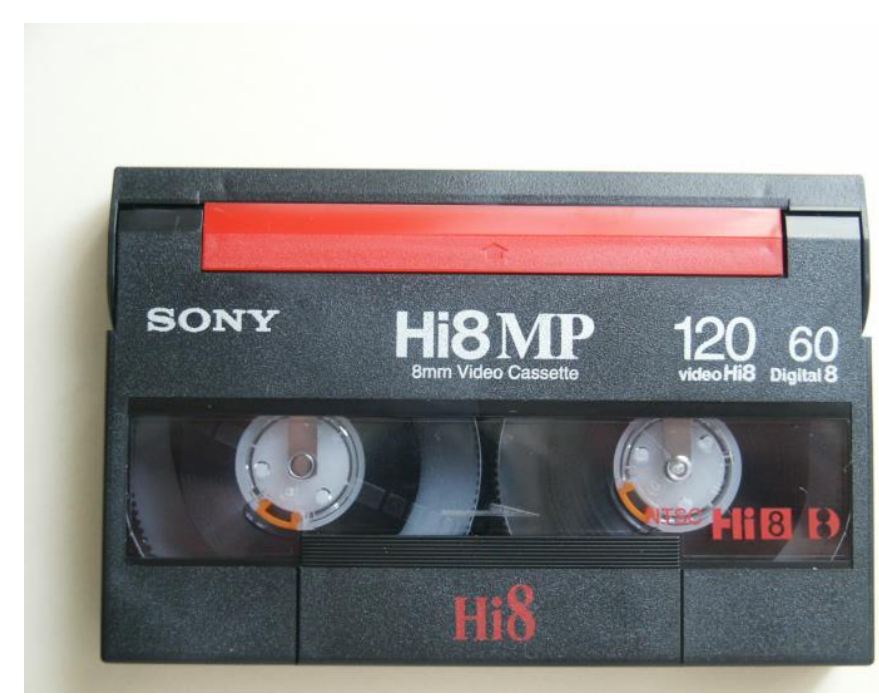

FIGURA 13: FITA DE VÍDEO PADRÃO DIGITAL $8{ }^{\circledR}$

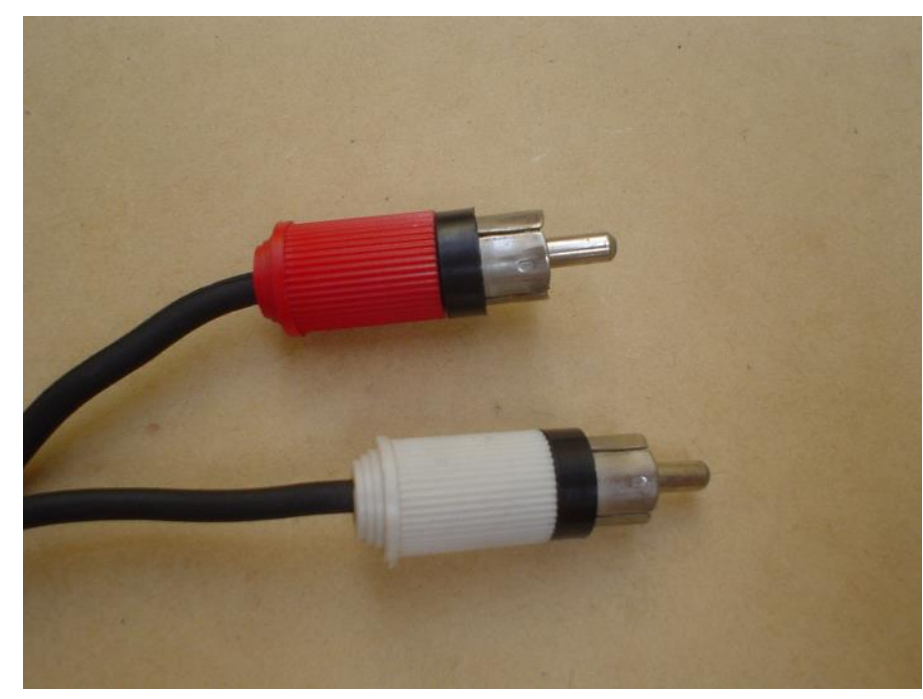

FIGURA 14: CABO DE VÍDEO RCA

Os padrões de configuração da câmera de vídeo digital SONY Modelo TRV340 ${ }^{\circledR}$ no momento da gravação foram: 


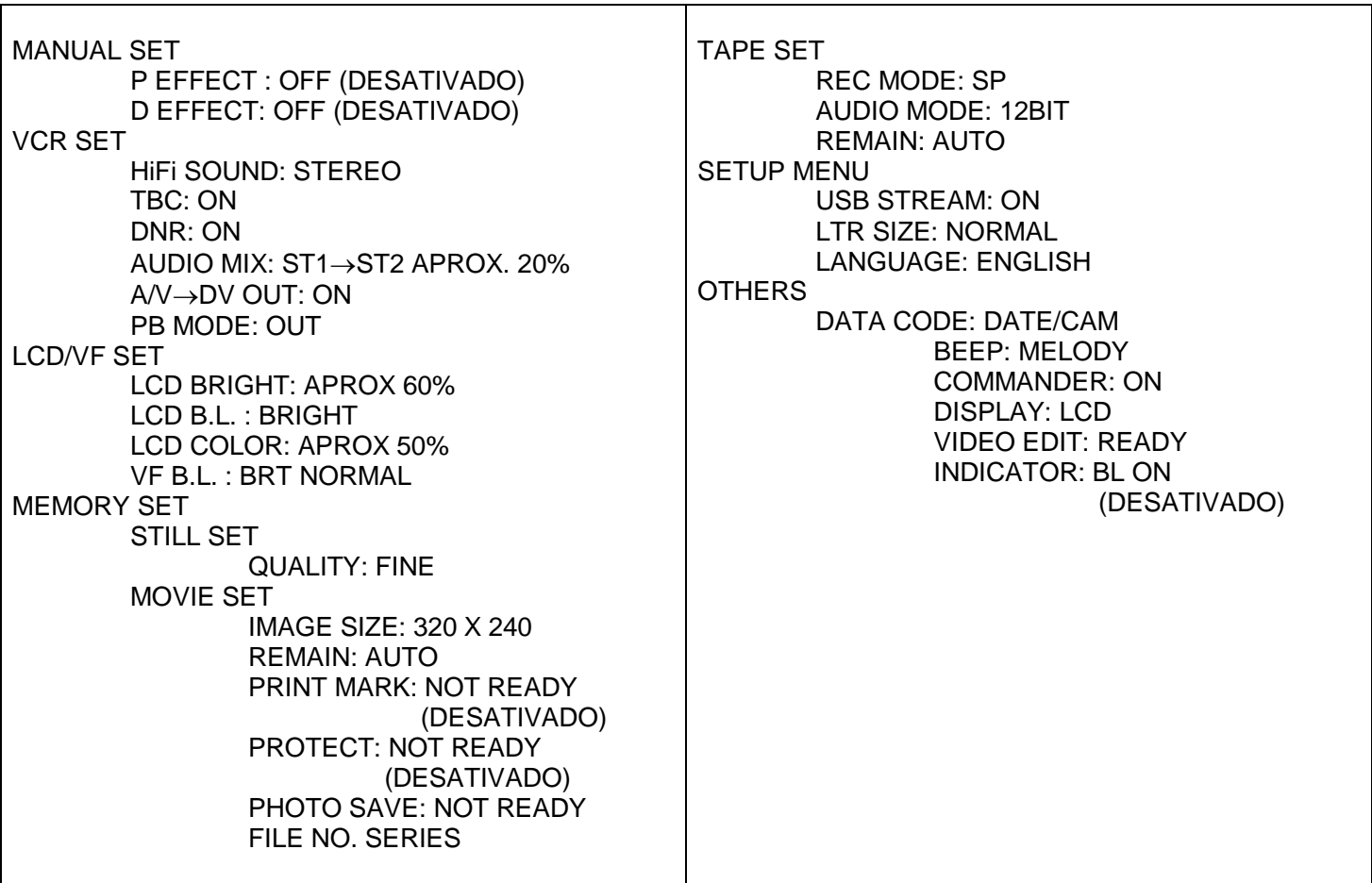

\subsection{Captura das imagens para o disco rígido do computador:}

As imagens então contidas nas fitas digitais foram capturadas digitalmente para o disco rígido de um computador com as seguintes características principais:

- $\quad$ Microcomputador IBM PC com CPU Intel ® Pentium IV

- $2 \mathrm{GHz}$ de velocidade de clock

- 512 MB de memória RAM tipo RAMBUS

- Disco rígido Seagate ST380023A IDE Ultra ATA Barracuda ATA V de 9,5 ms (seek time) e 7200 rpm (rotações por minuto). Versão do driver 5.1.2535.0 Micorsoft Windows Publisher. 
- Adaptador de vídeo NVIDIA RIVA TNT2 Model 64, AGP, driver versão 5.1.2001.0 fornecido por Microsoft Windows XP Publisher, $32 \mathrm{MB}$ de memória. Conversor analógico-digital Integrated RAMDAC. Aceleração de hardware máxima.

- Gravador/leitor de DVD +R/RW -R/RW SONY modelo DRU-500A, configurado para região 4 , driver versão 5.1.2535.0 fornecido por Microsoft Windows Publisher de 1/7/2001 com modo DMA ativado.

- Monitor LG Flatron 775FT, tela plana, de 17 polegadas, operando em resolução de 1024 por 768 pixels e qualidade de cor de 32 bits e freqüência de atualização da tela de $60 \mathrm{~Hz}$. Driver 5.1.2001.0 fornecido por Microsoft Windows XP Publisher.

- Controlador IEEE 1394 Firewire Bus PCI, Pinnacle, driver versão 5.1.2535.0 fornecido por Microsoft Windows Publisher

- Sistema operacional Microsoft Windows XP Professional Versão 2002 - Service Pack 1

A câmera SONY TRV-340 e o computador foram conectados através de um cabo tipo IEE1394 Firewire (Figura 15) e as imagens capturadas utilizando o software Pinnacle Studio Versão 8.5.21.0. da empresa Pinnacle Systems utilizando-se a janela de captura (Figura 16). 


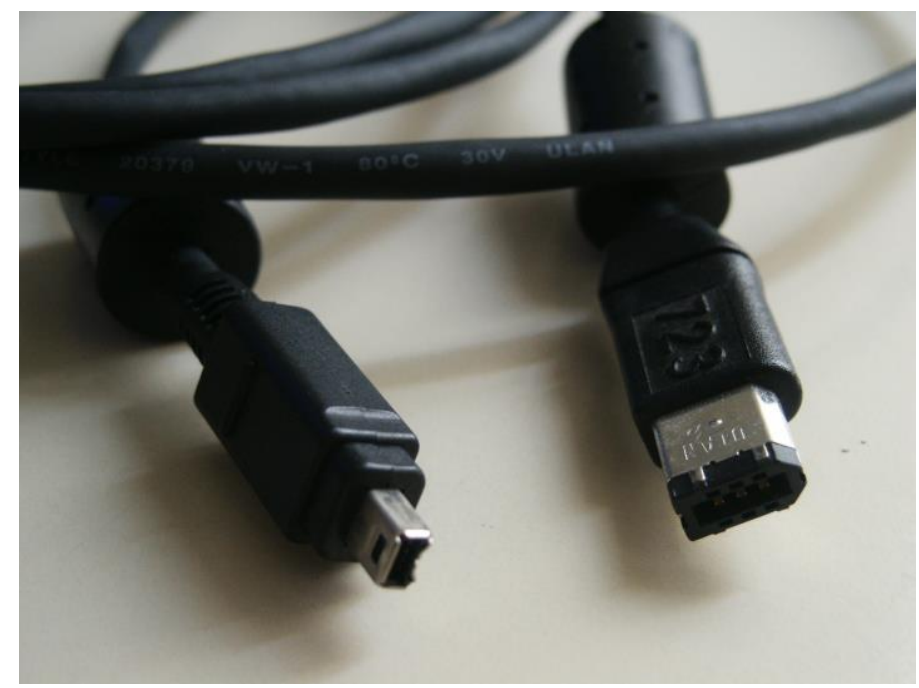

FIGURA 15: CABO IEE1394 FIREWIRE

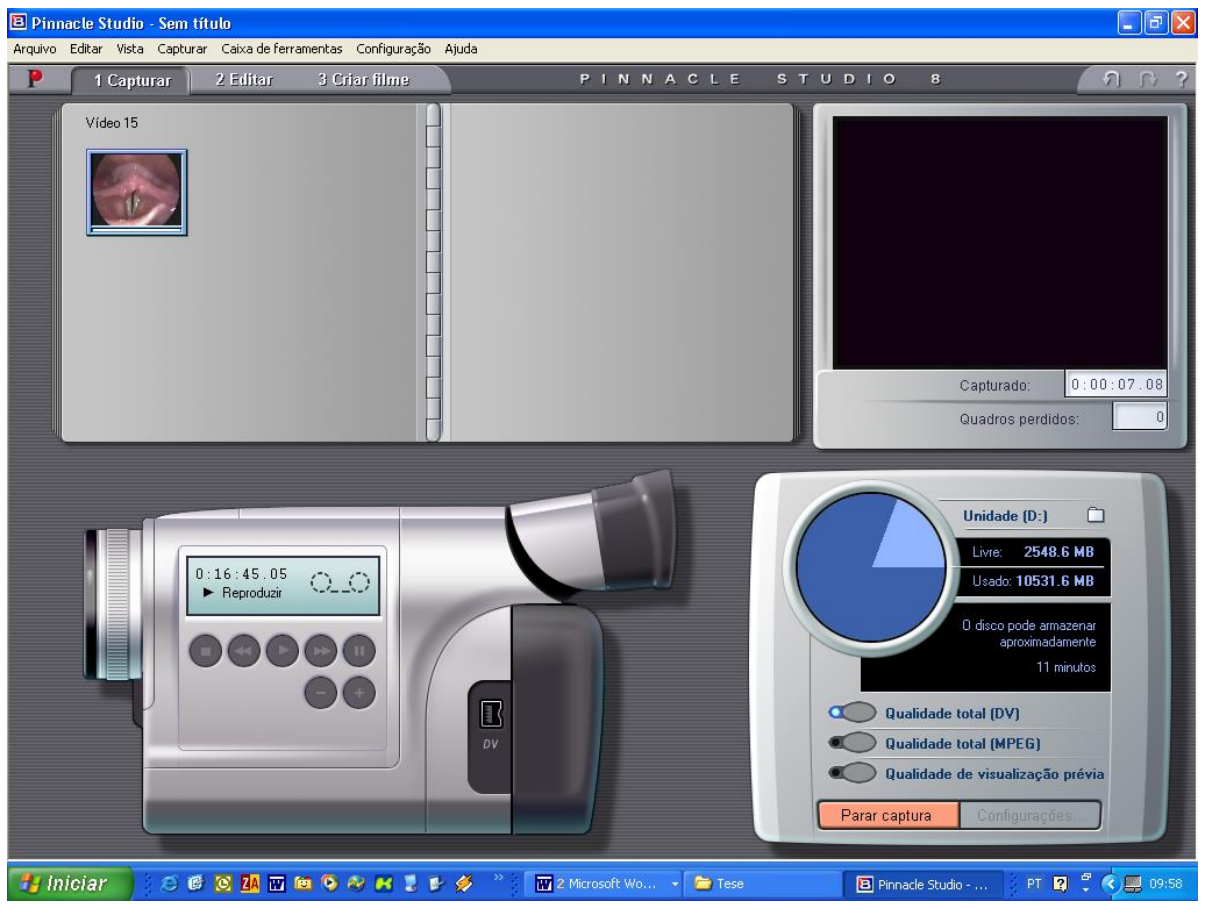

FIGURA 16: JANELA DE CAPTURA DO SOFTWARE

Foram selecionados os seguintes parâmetros de captura: 


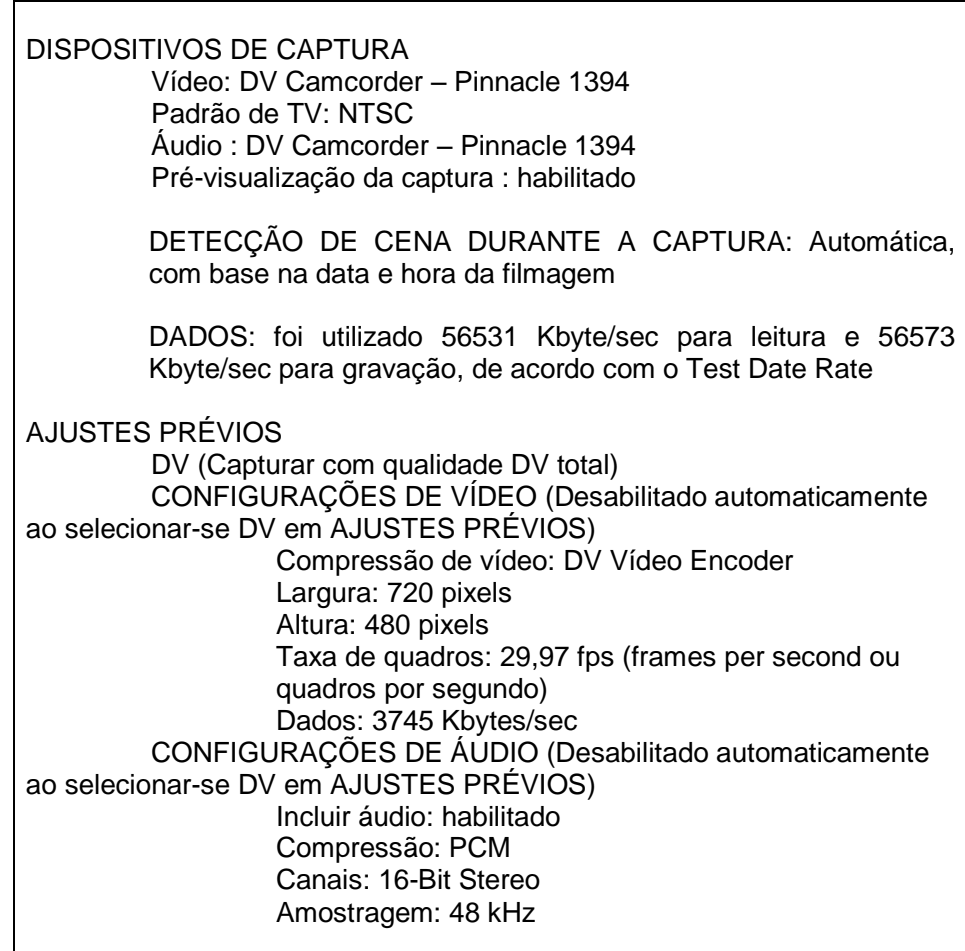

\section{Clicando-se na aba Editar, foram selecionados:}

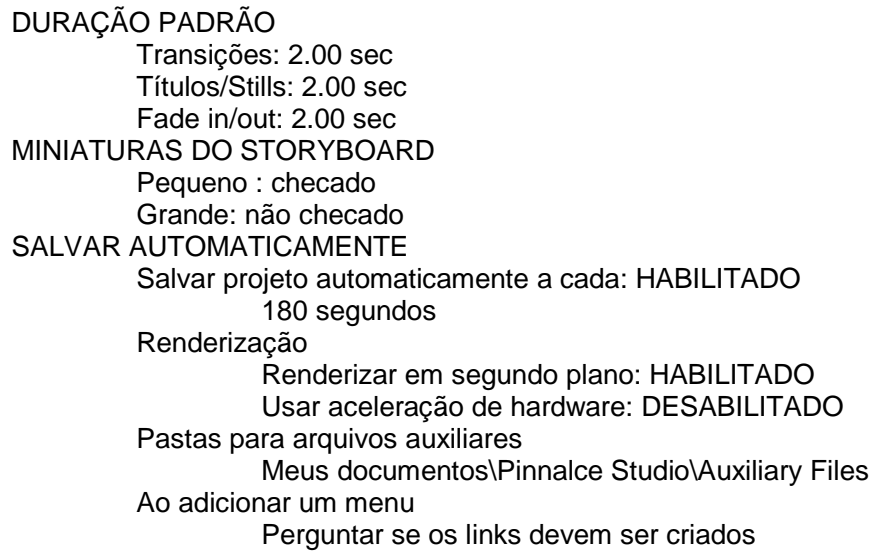

Em todas as imagens capturadas, não houve perda de nenhum quadro devido à conexão estável e de alta velocidade (400 Mbps pela porta IEE1394), entre a câmera e o microcomputador. 
O processo acima foi repetido para cada uma das 60 imagens escolhidas e numeradas de 1 a 60.

Foi realizada então a edição das imagens propriamente dita.

\subsection{Edição das imagens capturadas pelo disco rígido}

O mesmo software foi utilizado para edição das imagens selecionadas. Procedemos aos cortes dos quadros que continham alguma identificação do paciente ou instituição, seja na forma de filmagem da ficha de consulta previamente ou posteriormente ao exame ou na apresentação de sua face durante a introdução ou retirada do nasofibroscópio ou telescópio. Também excluímos trechos com imagem desfocada ou que não estivessem mostrando a hipofaringe ou laringe.

Uma vez finalizada a edição, utilizamos o recurso de "CRIAR FILME" do software para gravar no disco rígido a imagem finalizada (Figura 17). 0 filme foi criado no formato $\mathrm{AVI}$, com os seguintes parâmetros:

CONFIGURAÇÕES DE VÍDEO

Incluir vídeo no arquivo AVI

COMPRESSÃO

DV Video Encoder

Largura: 720 pixels

Altura: 480 pixels

Quadros/s: 29,97 fps (frames per second ou quadros por segundo) Kbytes/s: 3745 Kbytes/sec

CONFIGURAÇÕES DE ÁUDIO (Desabilitado automaticamente ao selecionarse DV em PRESETS)

Incluir áudio no arquivo AVI: habilitado

Tipo: PCM

Canais: 16-Bit Stereo

Amostragem: $32 \mathrm{kHz}$ 


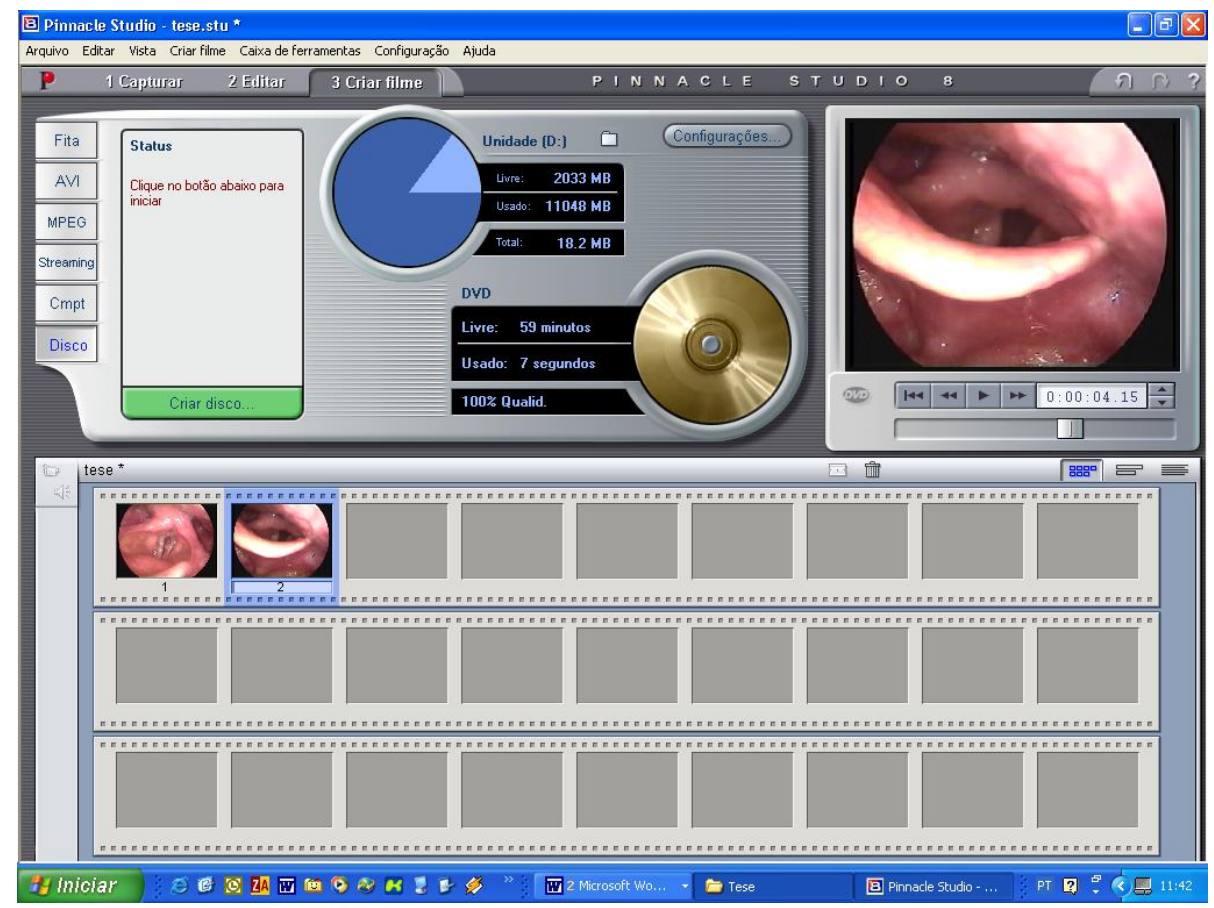

FIGURA 17: JANELA CRIAR FILME

Todo o procedimento de edição acima foi realizado para cada uma de todas as 60 imagens escolhidas inicialmente.

\subsection{Encadeamento e identificação das imagens editadas}

Após a edição das imagens individualmente, precisamos criar uma seqüência identificada de todas elas. Para isso utilizamos a mesma janela de edição do Pinnacle Studio (EDITAR). Inserimos seqüencialmente os vídeos de número 1 ao 31, gravados como Video1o.avi, Video2o.avi, ..., até Video31.avi. em uma pasta do disco rígido rotulada de ORIGINAL. e os identificamos numericamente no início, resultando em um vídeo com duração total de aproximadamente 50 minutos (as fitas Digital $8^{\circledR}$ suportam no máximo 59 minutos no formato DV). 
Utilizando a função "CRIAR FITA" do software, o computador renderizou a seqüência de imagens, e as enviou para serem gravadas na câmera SONY TRV-340 em fita Digital $8^{\circledR}$ em formato DV. Esta fita foi rotulada como ORIGINAL 1. O mesmo procedimento foi realizado com os vídeos de número 32 a 60, gerando a fita ORIGINAL 2. As configurações utilizadas nesse processo foram:

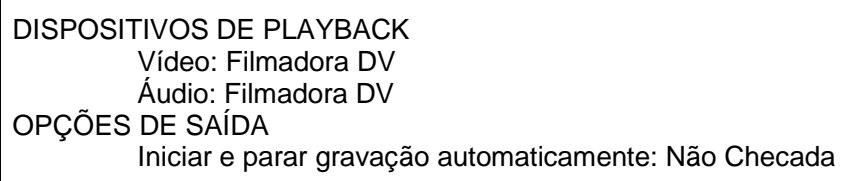

\subsection{Transmissão das fitas originais 1 e 2 por VC}

A câmera SONY TRV 340 e as duas fitas resultantes foram levadas para o Departamento de Telemedicina da Faculdade de Medicina da Universidade de São Paulo, na cidade de São Paulo, estado de São Paulo, Brasil e sua saída de vídeo SVHS foi conectada à entrada SVHS de um equipamento de VC Tandberg 6000 (Figura 18) conectado a 4 linhas ISDN, cada uma delas com banda de $128 \mathrm{kbps}$ fornecidas pela operadora Telefônica da cidade de São Paulo, totalizando uma taxa de transferência de 512 kbps para a comunicação. 


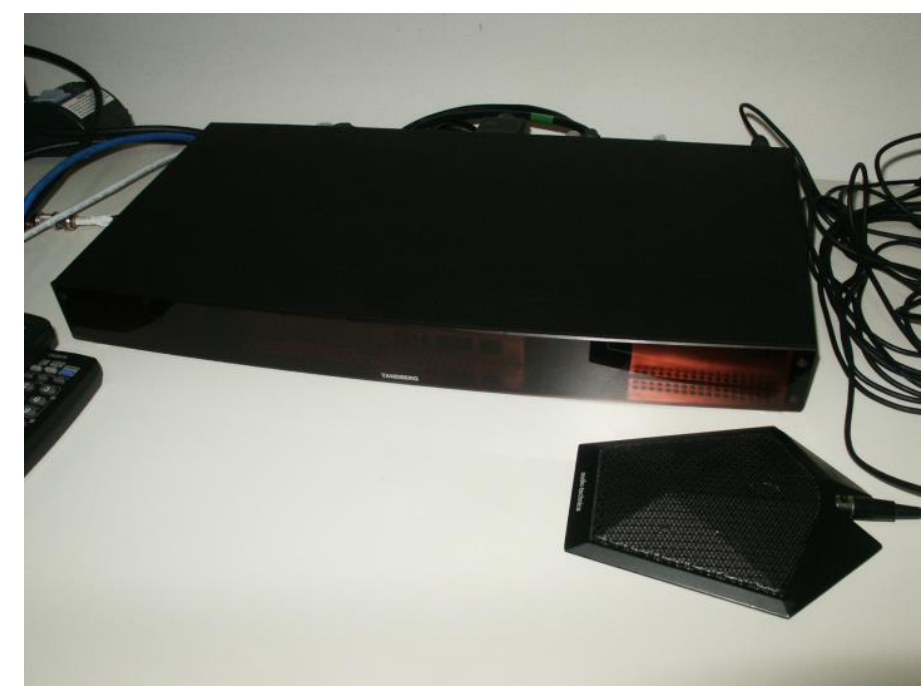

FIGURA 18: VISÃO FRONTAL DO APARELHO TANDBERG 6000

Ao mesmo tempo, no Departamento de Informática da Faculdade de Medicina do ABC, sala de VC, na cidade de Santo André, estado de São Paulo, Brasil, foi conectada a entrada SVHS de outra câmera de vídeo SONY TRV 340 (com uma fita Digital $8^{\circledR}$ ) à saída SVHS de um equipamento de VC da marca Polycom modelo View Station (Figura 19), também conectadas a 4 linhas ISDN da Embratel (Empresa Brasileira de Telecomunicações), fornecendo uma taxa de transferência de 512 kbps.

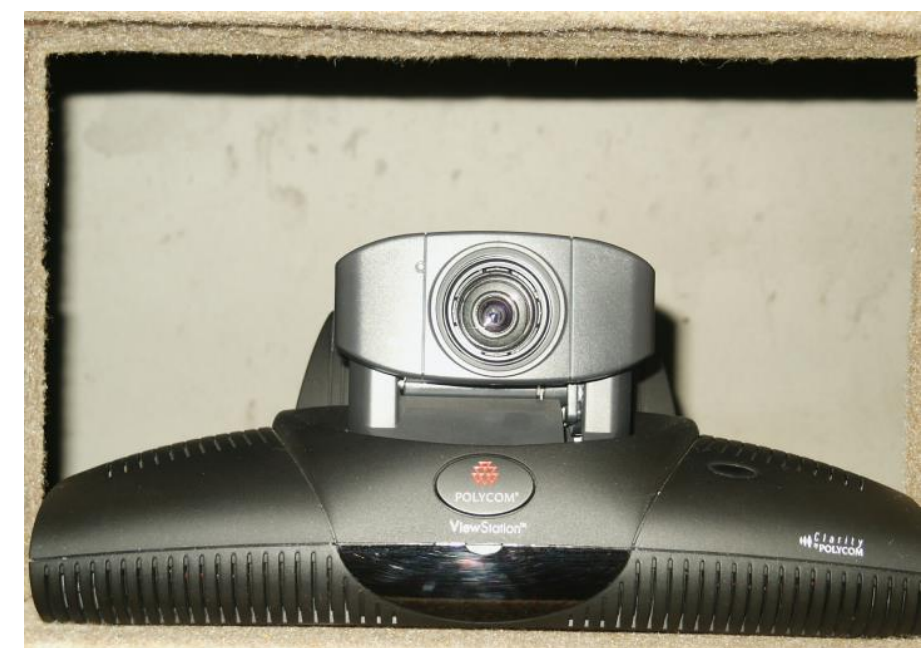

FIGURA 19: VISÃO FRONTAL DO APARELHO POLYCOM VIEW STATION 
Um técnico já familiarizado com o equipamento estava presente na FMABC e outro na FMUSP comunicados por telefone convencional.

Foi estabelecida a comunicação, sendo a chamada originada do aparelho TANDBERG da FMUSP e recebida pelo aparelho POLYCOM da FMABC, ocupando-se todos os 8 canais de 64 kbps cada (4 linhas ISDN de 128 kbps cada uma).

Ao mesmo tempo em que a fita ORIGINAL 1 era iniciada pressionando-se a tecla PLAY no painel de controle da câmera conectada na FMUSP, a gravação era efetuada na câmera conectada na FMABC pressionando-se a tecla dupla de gravação da câmera. Ao término da gravação a fita gravada foi rotulada como VC 1. O mesmo procedimento foi realizado com a fita ORIGINAL 2 gerando a fita VC 2.

Durante toda a transmissão o técnico situado na FMABC esteve em contato com o técnico da FMUSP via telefonia convencional para relatar possíveis intercorrências como quedas de transmissão ou diminuições bruscas decorrentes de problemas nas linhas durante o procedimento. Nenhuma intercorrência foi relatada e a transmissão foi estável e sem oscilações durante todo o período. A transmissão foi realizada segundo o protocolo padrão H.320.

As estatísticas da rede durante todo o período da transmissão, informadas pelo equipamento transmissor TANDBERG, estão registradas na Tabela 2. 
TABELA 2 - ESTATÍSTICAS DA REDE DURANTE A TRANSMISSÃO INFORMADAS PELO APARELHO TANDBERG

\begin{tabular}{ccc}
\hline & estatística da rede & \\
\hline & $\mathrm{T}$ & $\mathrm{R}$ \\
\hline velocidade chamada (kbps) & 512 & 512 \\
protocolo de vídeo & $\mathrm{H} 263$ & $\mathrm{H} 263$ \\
protocolo de áudio & $\mathrm{G} .722$ & $\mathrm{G} .722$ \\
protocolo de dados & nenhum & nenhum \\
formato de vídeo & $\mathrm{CIF}$ & $\mathrm{CIF}$ \\
velocidade de vídeo (kbps) & 454.4 & 454.4 \\
velocidade de áudio (kbps) & 56.0 & 56.0 \\
veloc./canal de dados & não/0.0 & $=$ \\
IPCR/perda de pacote & - & - \\
estado de encriptação & não & não \\
\hline
\end{tabular}

As estatísticas da rede durante todo o período da transmissão, informadas pelo equipamento receptor da transmissão POLYCOM, encontram-se na Tabela 3.

TABELA 3 - ESTATÍSTICAS DA REDE DURANTE A TRANSMISSÃO INFORMADAS PELO APARELHO POLYCOM

\begin{tabular}{ccc}
\hline & estatística da rede & \\
\hline & $\mathrm{B} 1$ & $\mathrm{~B} 2$ \\
\hline taxa Sincronismo TX & 512 & - \\
taxa Sincronismo RX & 512 & - \\
erros & - & - \\
sinc & - & $\mathrm{H} 263$ \\
protocolo de vídeo & $\mathrm{H} 263$ & $\mathrm{CIF}$ \\
formato de vídeo & $\mathrm{CIF}$ & $\mathrm{G} .722$ \\
protocolo de áudio & $\mathrm{G} .722$ & $\mathrm{H} .320$ \\
comunicação & $\mathrm{H} .320$ &
\end{tabular}

O conteúdo das fitas resultantes de VC (VC1 e VC2) foi transferido da câmera de vídeo SONY TRV 340 para o disco rígido do mesmo computador descrito anteriormente via cabo de comunicação IEE1394 Firewire. Também foram editadas utilizando-se o software Pinnacle Studio, sendo removidos todos os títulos de identificação seqüenciais. As imagens resultantes, sem os 
títulos, foram gravadas novamente como Vídeo1v.avi,Vídeo2v.avi, ... até Video60v.avi. e armazenadas em uma pasta do disco rígido rotulada de VIDEOCONF. Estas imagens são exatamente as mesmas imagens originais, porém obtidas após a transmissão por VC.

\subsection{Criação das conteúdos finais para gravação dos DVDs A e B}

No total obtivemos 60 pares de imagens armazenadas no disco rígido, sendo 60 originais e as mesmas 60 transmitidas por VC. Com esse material criamos no computador duas pastas (A e B). Para cada pasta foi transferida uma das imagens do par, totalizando 60 imagens, das quais 30 eram originais (15 telescopias e 15 fibroscopias) e 30 por VC (15 telescopias e 15 fibroscopias). Desse modo, cada pasta é complementar à outra, tendo uma das imagens do par. Dividimos as imagens com diagnósticos semelhantes (normais, nódulos, pólipo, cistos, etc.) de maneira equilibrada entre imagens originais e VC e entre telescopias e fibroscopias.

A distribuição de imagens nas pastas A e B está informada na Tabela 4.

TABELA 4 - DISTRIBUIÇÃO DAS IMAGENS NAS PASTAS A E B CRIADAS NO COMPUTADOR

\begin{tabular}{ccccc}
\hline $\begin{array}{c}\text { número } \\
\text { da } \\
\text { imagem }\end{array}$ & Pasta A & Pasta B laringoscopia & diagnóstico \\
\hline 1 & $\mathrm{~V}$ & $\mathrm{O}$ & $\mathrm{T}$ & carcinoma de pv E \\
2 & $\mathrm{O}$ & $\mathrm{V}$ & $\mathrm{F}$ & paralisia de pv D \\
3 & $\mathrm{O}$ & $\mathrm{V}$ & $\mathrm{T}$ & cisto de pv D \\
4 & $\mathrm{O}$ & $\mathrm{V}$ & $\mathrm{T}$ & papilomatose \\
5 & $\mathrm{~V}$ & $\mathrm{O}$ & $\mathrm{T}$ & pólipo angiomatoso \\
6 & $\mathrm{O}$ & $\mathrm{V}$ & $\mathrm{T}$ & fenda \\
7 & $\mathrm{O}$ & $\mathrm{V}$ & $\mathrm{T}$ & leucoplasia de pv D \\
8 & $\mathrm{~V}$ & $\mathrm{O}$ & $\mathrm{F}$ & pólipo de pv E \\
9 & $\mathrm{O}$ & $\mathrm{V}$ & $\mathrm{F}$ & papiloma de pv E
\end{tabular}




\begin{tabular}{|c|c|c|c|c|}
\hline $\begin{array}{c}\text { número } \\
\text { da } \\
\text { imagem }\end{array}$ & Pasta A & Pasta B & laringoscopia & diagnóstico \\
\hline 10 & $\mathrm{~V}$ & $\mathrm{O}$ & $\mathrm{F}$ & nódulos vocais \\
\hline 11 & $\mathrm{O}$ & $\mathrm{V}$ & $\mathrm{T}$ & papilomatose \\
\hline 12 & $\mathrm{O}$ & V & $\mathrm{F}$ & membrana laríngea \\
\hline 13 & V & $\mathrm{O}$ & $\mathrm{T}$ & fenda + sulco \\
\hline 14 & $\mathrm{O}$ & $\mathrm{V}$ & $\mathrm{T}$ & luxação de aritenóide \\
\hline 15 & $\mathrm{O}$ & V & $\mathrm{T}$ & sulco pve + fenda fusiforme \\
\hline 16 & $\mathrm{O}$ & V & $\mathrm{F}$ & normal \\
\hline 17 & $\mathrm{O}$ & V & $\mathrm{F}$ & estenose subglotica \\
\hline 18 & V & $\mathrm{O}$ & $\mathrm{F}$ & edema de reinke \\
\hline 19 & V & $\mathrm{O}$ & $\mathrm{T}$ & nódulos vocais \\
\hline 20 & $\mathrm{O}$ & V & $\mathrm{T}$ & paralisia de pv E \\
\hline 21 & V & $\mathrm{O}$ & $\mathrm{F}$ & leucoplasia de ppvv \\
\hline 22 & V & $\mathrm{O}$ & $\mathrm{F}$ & carcinoma \\
\hline 23 & $\mathrm{O}$ & V & $\mathrm{F}$ & pólipo de pv E \\
\hline 24 & V & $\mathrm{O}$ & $\mathrm{F}$ & normal \\
\hline 25 & $\mathrm{O}$ & V & $\mathrm{T}$ & paralisia paramediana de pv $\mathrm{E}$ \\
\hline 26 & V & $\mathrm{O}$ & $\mathrm{T}$ & leucoplasia \\
\hline 27 & $\mathrm{O}$ & V & $\mathrm{F}$ & microweb \\
\hline 28 & V & $\mathrm{O}$ & $\mathrm{T}$ & sulco bilateral + fenda \\
\hline 29 & V & $\mathrm{O}$ & $\mathrm{T}$ & paralisa de ppvv em adução \\
\hline 30 & V & $\mathrm{O}$ & $\mathrm{T}$ & cisto de pv E + reação contralateral \\
\hline 31 & $\mathrm{O}$ & V & $\mathrm{F}$ & pólipo vocal \\
\hline 32 & V & $\mathrm{O}$ & $\mathrm{F}$ & cisto em prega vestibular \\
\hline 33 & $\mathrm{O}$ & V & $\mathrm{T}$ & edema de reinke \\
\hline 34 & $\mathrm{~V}$ & $\mathrm{O}$ & $F$ & paralisia de pv D \\
\hline 35 & V & $\mathrm{O}$ & $\mathrm{T}$ & cisto de pv D \\
\hline 36 & $\mathrm{O}$ & V & $\mathrm{T}$ & vasculodisgenesia de pv D \\
\hline 37 & $\mathrm{O}$ & V & $\mathrm{F}$ & cisto de pv E \\
\hline 38 & V & 0 & $\mathrm{~T}$ & normal \\
\hline 39 & $\mathrm{O}$ & V & $\mathrm{F}$ & carcinoma de seio piriforme $\mathrm{E}$ \\
\hline 40 & V & $\mathrm{O}$ & $\mathrm{T}$ & fenda paralela ântero - posterior \\
\hline 41 & V & $\mathrm{O}$ & $\mathrm{F}$ & edema de Reinke \\
\hline 42 & V & 0 & $\mathrm{~T}$ & papiloma \\
\hline 43 & $\mathrm{O}$ & V & $\mathrm{F}$ & nódulos vocais \\
\hline 44 & 0 & V & $\mathrm{F}$ & carcinoma de epiglote \\
\hline 45 & V & $\mathrm{O}$ & $\mathrm{T}$ & pólipo de pv E \\
\hline 46 & 0 & V & $\mathrm{T}$ & normal \\
\hline 47 & V & $\mathrm{O}$ & $\mathrm{F}$ & nódulos vocais \\
\hline 48 & V & $\mathrm{O}$ & $\mathrm{T}$ & leucoplasia \\
\hline 49 & V & $\mathrm{O}$ & $\mathrm{F}$ & $\begin{array}{c}\text { vasculodisgenesia }+ \text { espessamento } \\
\text { mucoso }\end{array}$ \\
\hline 50 & $\mathrm{O}$ & V & $\mathrm{T}$ & polipo angiomatoso de pv E \\
\hline 51 & $\mathrm{O}$ & V & $\mathrm{F}$ & leucoplasia de pv E \\
\hline 52 & V & $\mathrm{O}$ & $\mathrm{F}$ & normal \\
\hline 53 & $\mathrm{O}$ & V & $\mathrm{F}$ & fenda triangular posterior \\
\hline 54 & $\mathrm{O}$ & $\mathrm{V}$ & $\mathrm{F}$ & nódulos vocais \\
\hline 55 & 0 & V & $\mathrm{F}$ & edema de Reinke \\
\hline 56 & V & $\mathrm{O}$ & $\mathrm{T}$ & cisto de pv E \\
\hline
\end{tabular}




\begin{tabular}{ccccc}
$\begin{array}{c}\text { conclusão } \\
\text { número } \\
\text { da } \\
\text { imagem }\end{array}$ & Pasta A & Pasta B laringoscopia & diagnóstico \\
\hline 57 & $\mathrm{~V}$ & $\mathrm{O}$ & $\mathrm{F}$ & estenose supraglotica \\
58 & $\mathrm{O}$ & $\mathrm{V}$ & $\mathrm{T}$ & carcinoma de pv D \\
59 & $\mathrm{~V}$ & $\mathrm{O}$ & $\mathrm{T}$ & membrana laringea \\
60 & $\mathrm{~V}$ & $\mathrm{O}$ & $\mathrm{F}$ & papiloma \\
\hline
\end{tabular}

Uma vez preparadas as pastas, as imagens foram transferidas para DVD. Após o processo de renderização pelo software Pinnacle Studio $8^{\circledR}$ foi realizada a gravação em mídia S-MAC DVD-R ${ }$ Premium, de 4,7 Gb, formato DVD-R® (Figura 20).

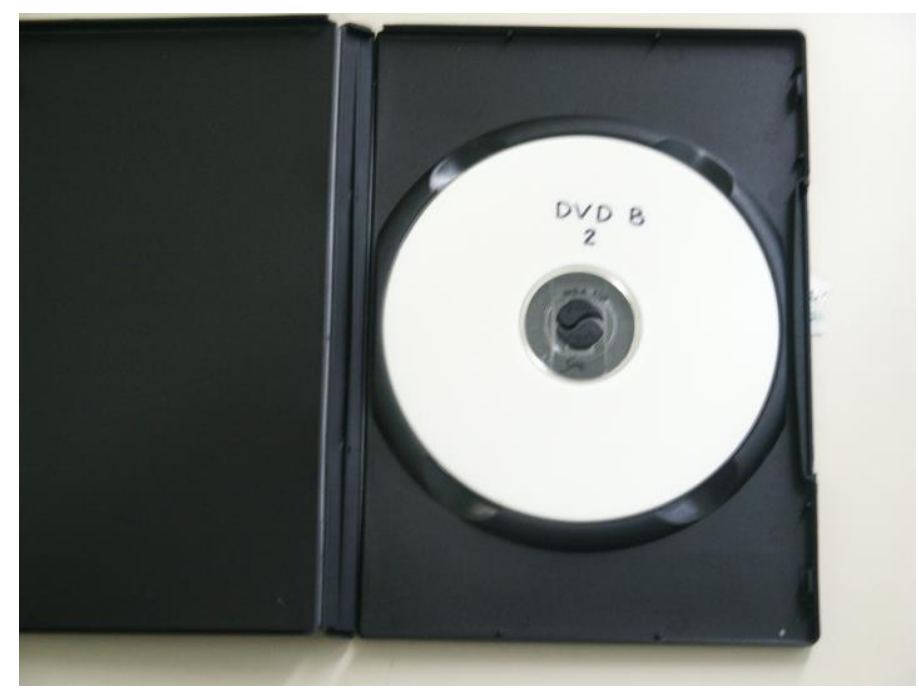

FIGURA 20: MÍDIA DE DVD-R S-MAC PREMIUM 4,7 GB

Como cada DVD comporta apenas 59 minutos de gravação em máxima resolução, o conteúdo da pasta $A$ foi dividido em dois DVDs, A1 e A2, contendo respectivamente uma das imagens dos pares 1 a 31 (DVD-A1) e dos pares 32 a 60 (DVD-A2). O mesmo ocorreu com a pasta B e os DVDB1 e DVD-B2. 
Para que o examinador tivesse um parâmetro para seu julgamento, foram inseridos exemplos de uma imagem de qualidade ruim (escore 0) e uma imagem de qualidade ótima (escore 3) no início dos DVDs 1 (A e B).

Na gravação dos DVDs foram utilizadas as seguintes configurações:

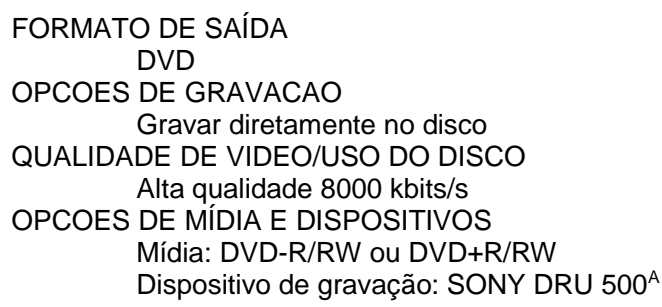

\subsection{Criação do DVD pareado (DVDPAR)}

Das 120 imagens gravadas no disco rígido do computador (60

originais e 60 por VC) foram selecionados 26 pares de imagens (sendo 13 de fibroscopia e 13 de telescopia) para a confecção de um outro DVD (DVDPAR). As imagens foram selecionadas aleatoriamente, porém com o cuidado de se diversificar os diagnósticos. Foi criado no computador a pasta PAR, na qual os pares de imagens foram colocados de forma agrupada, ora sendo apresentado primeiro a imagem original, ora a de VC, de forma aleatória. Em 6 casos foram colocadas as duas imagens originais. Não foram colocadas duas imagens de VC.

A seqüência das imagens está apresentada na Tabela 5. 
TABELA 5 - DISTRIBUIÇÃO DOS PARES DE IMAGENS NA PASTA PAR.

\begin{tabular}{cccc}
\hline $\begin{array}{c}\text { ordem do par de } \\
\text { imagens }\end{array}$ & $\begin{array}{c}\text { primeira imagem } \\
\text { imagem do par }\end{array}$ & $\begin{array}{c}\text { segunda imagem } \\
\text { do par }\end{array}$ & laringoscopia \\
\hline 1 & VC & O & fibroscopia \\
2 & O & VC & fibroscopia \\
3 & VC & O & fibroscopia \\
4 & VC & fibroscopia \\
5 & O & O & fibroscopia \\
6 & VC & O & fibroscopia \\
7 & O & O & fibroscopia \\
8 & O & VC & fibroscopia \\
9 & O & VC & fibroscopia \\
10 & VC & O & fibroscopia \\
11 & O & VC & fibroscopia \\
12 & O & O & fibroscopia \\
13 & fibroscopia \\
14 & O & VC & telescopia \\
15 & VC & O & telescopia \\
16 & VC & O & telescopia \\
17 & VC & O & telescopia \\
18 & O & VC & telescopia \\
19 & O & O & telescopia \\
20 & VC & O & telescopia \\
21 & O & VC & telescopia \\
22 & VC & O & telescopia \\
23 & O & VC & telescopia \\
24 & $O$ & O & telescopia \\
25 & VC & O & telescopia \\
26 & O & VC & \\
\hline
\end{tabular}

VC - videoconferência

$\mathrm{O}$ - original

As imagens foram colocadas seqüencialmente na janela de filme do software Pinnacle Studio $8^{\circledR}$ e cada par foi precedido por uma identificação numérica. As primeiras imagens dos pares foram identificadas como $A$ e as segundas como B (Figura 21). 


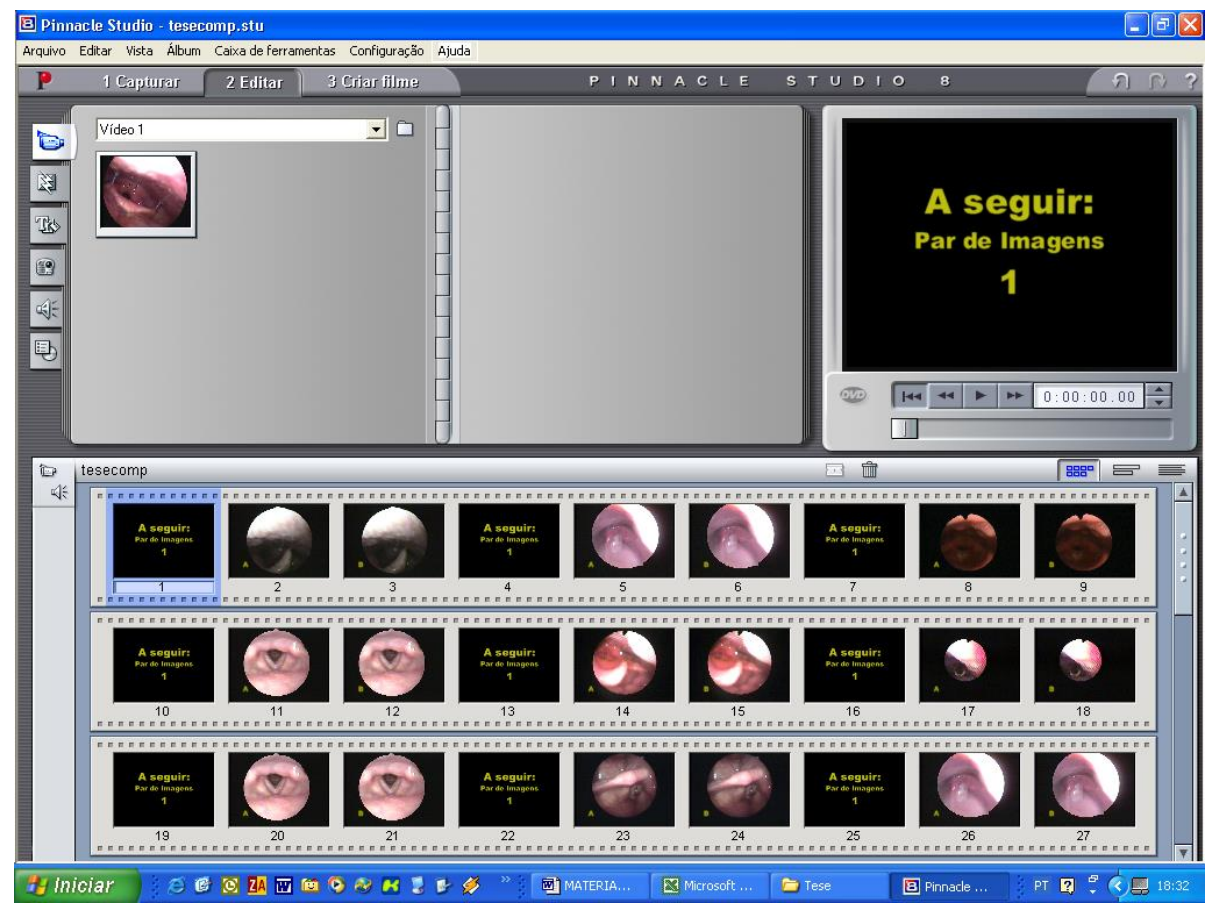

FIGURA 21: TELA DE EDIÇÃO COM O FILME DVDCOMP, COM PARES DE IMAGENS

A partir do conteúdo da pasta PAR as imagens foram transferidas para um DVD rotulado como DVDPAR.

\subsection{Análise dos examinadores}

Foram convidados a participar do estudo 6 otorrinolaringologistas com título de especialista pela Sociedade Brasileira de Otorrinolaringologia, com experiência na análise de imagens de laringe. Três deles são integrantes do corpo clínico da Divisão de Clínica Otorrinolaringológica do Hospital das Clínicas da Faculdade de Medicina da USP e três do Departamento de Otorrinolaringologia da Faculdade de Medicina do ABC.

A três deles foram cedidos para análise os DVDs A1 e A2 e aos outros três os DVDs B1 e B2. Após a análise desse material, todos eles receberam também o DVDPAR para análise. Todos os examinadores utilizaram o mesmo aparelho leitor de DVD (SONY Modelo DVD-315) 
(Figura 22) e o mesmo televisor (PHILCO, SVHS tela plana, modelo TPF2121 de 21 polegadas) (Figura 23), conectados por um cabo de vídeo padrão SVHS (Figura 24).

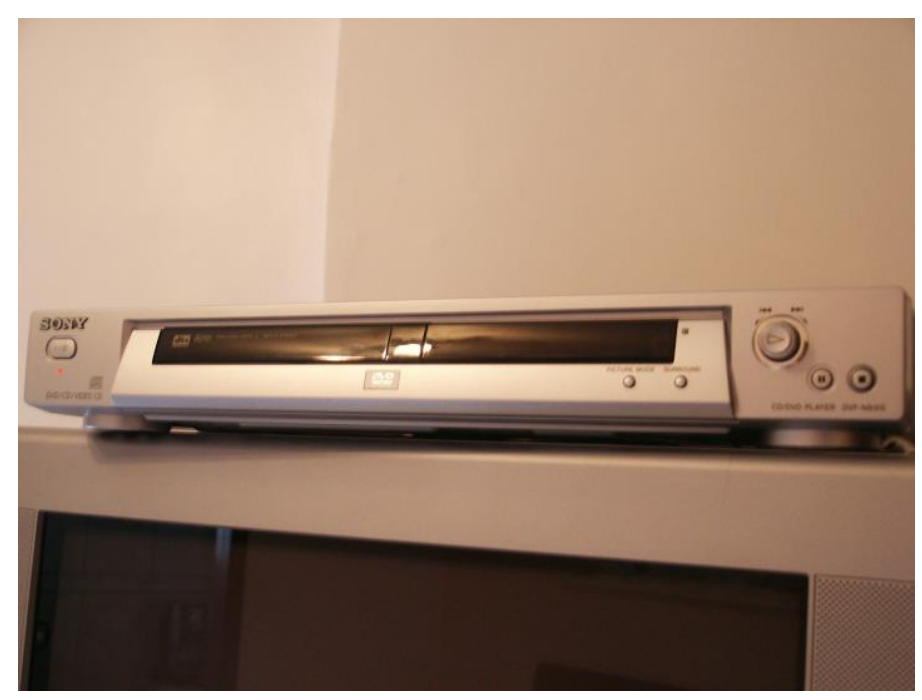

FIGURA 22: LEITOR DE DVD SONY DVD-315

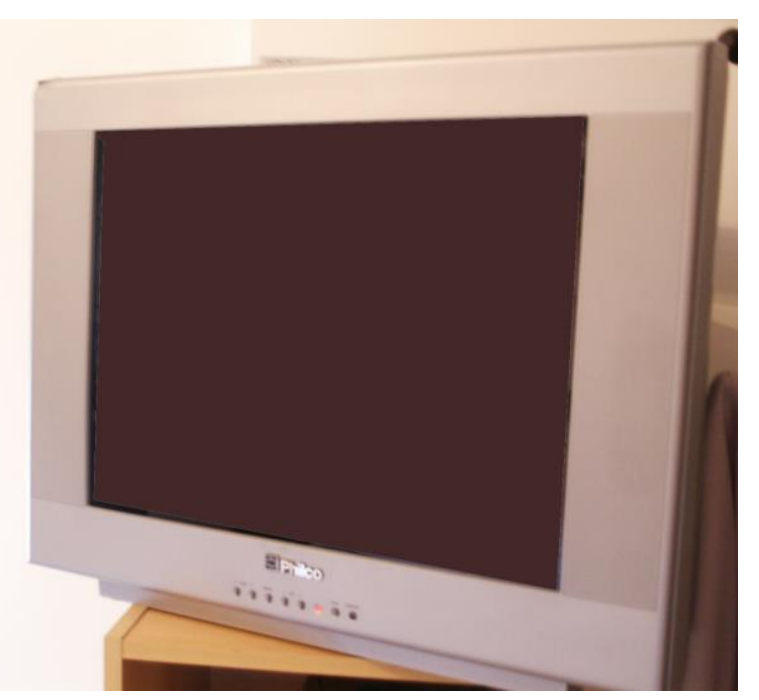

FIGURA 23: TELEVISOR PHILCO TPF-2121 


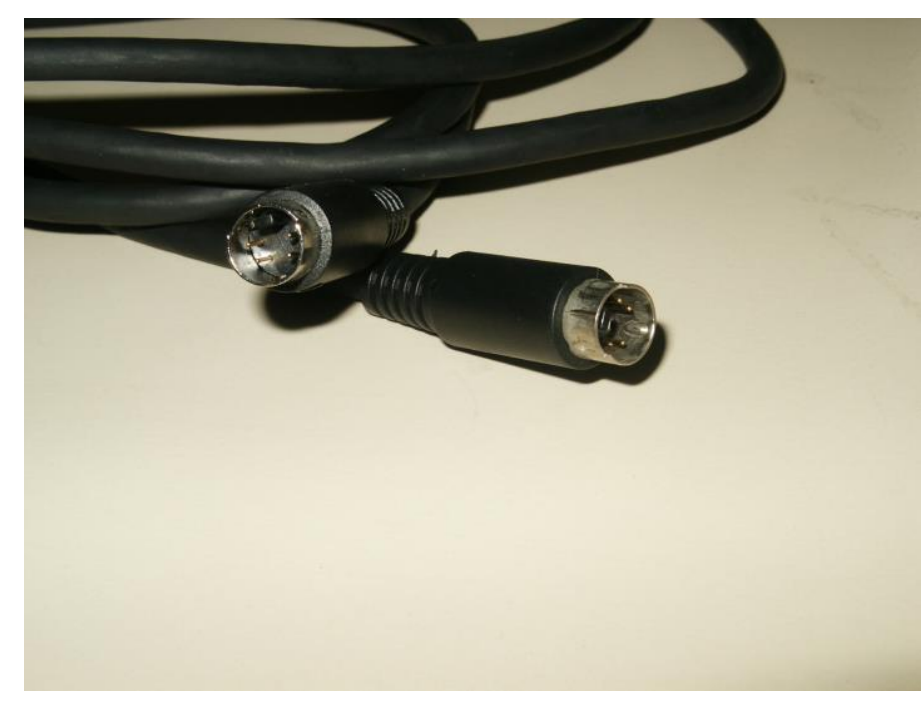

FIGURA 24: CABO SUPER -VHS

O televisor foi calibrado, em seu menu de entrada AV1 (onde foi conectada a saída de vídeo SVHS do aparelho leitor de DVD), com as seguintes configurações:

- Brilho : 8 de 16

- Contraste: $11 \frac{1}{2}$ de 16

- Cor: 10 1/2 de 16

- Nitidez: 8 de 16

A cada um dos especialistas foi entregue o seguinte protocolo para avaliação individual das estruturas anatômicas de cada imagem contida nos DVDs A e B: 


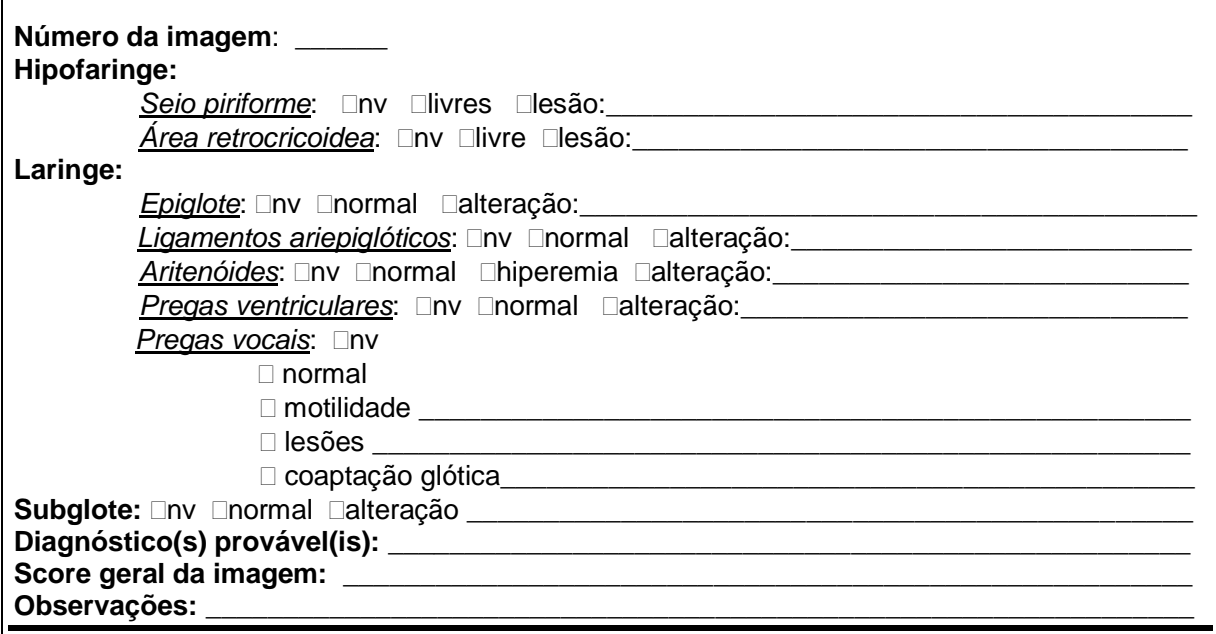

A qualidade das imagens foi classificada em:

0-imagem ruim

1-imagem regular

2-imagem boa

3-imagem ótima

Para cada imagem o examinador assinalou o achado para cada uma das estruturas anatômicas da hipofaringe, laringe e subglote. Quando o vídeo não mostrava determinada estrutura, foi assinalado o item "nv" (não visualizável). Ao final da avaliação das estruturas o examinador atribuiu um nível para qualidade baseando-se nas imagens padrões dos escores 0 (imagem ruim) e 3 (imagem ótima) gravadas no início dos DVDs A1 e B1.

Todos os DVDs (DVDA1, A2, B1 e B2) possuem um menu que pode ser acessado pelo botão TOP MENU do controle remoto do leitor de DVD, podendo-se navegar imediatamente para qualquer imagem desejada. Nos DVDA1 e B1 há também um item de menu que o levará para as "imagens 
padrões" utilizadas. Para pular de uma imagem para a seguinte ou anterior durante a visualização, podem ser utilizados os botões $>\mid$ ou $\mid<$ do controle remoto do aparelho de DVD, assim como sua velocidade aumentada ou retrocedida pressionando-se os botões $>$ ou $\ll$. O funcionamento é exatamente igual ao de um disco de DVD comercial.

Todos os examinadores receberam as seguintes orientações:

- Ao marcar um escore para determinada imagem ter em mente as imagens padrões apresentadas no início da gravação.

- Levar em conta apenas a qualidade da imagem e não a qualidade da técnica utilizada para a realização original do exame ou se deveriam se ater a algum ponto específico.

- Verificar as imagens sempre no mesmo monitor e no mesmo leitor de DVD (fornecidos em conjunto).

- De preferência não avaliar mais de 10 imagens seguidas para evitar ao máximo o fator fadiga.

- Entregar os resultados ao pesquisador responsável após o máximo de 15 dias do recebimento dos DVDs e equipamentos.

Para avaliação do DVDPAR, foi fornecido aos especialistas o seguinte protocolo para avaliação individual de cada par de imagens:

Par de imagens número:

Qualidade da imagem: $\square$ A é melhor $\square$ B é melhor $\square$ A semelhante a $B$

No caso de haver diferença, ela interfere na qualidade do diagnóstico? $\square$ Sim $\square$ Não

Qual imagem em sua opinião é a de videoconferência? $\square$ A $\square$ B $\square$ Nenhuma

Observações: 
Os examinadores foram orientados para que fosse avaliada cada uma das imagens do par e detectado, quando houvesse diferença, qual delas seria a imagem de melhor qualidade. No caso de haver diferença de qualidade entre as duas imagens foi questionado se ela interferiria no diagnóstico da lesão apresentada. Foi também solicitado aos examinadores responder qual imagem do par seria resultado da transmissão por VC ou se ambas as imagens eram originais.

\subsection{Análise da concordância diagnóstica nos DVDs A e B}

Para a análise do acerto nos diagnósticos dados às imagens pelos 6 examinadores (3 DVD A e 3 DVD B) dois juízes com a mesma experiência em laringologia, foram escolhidos para avaliá-los em relação ao diagnóstico original. Os critérios para as notas dadas ao acerto se basearam nos aspectos:

- Nota 2: acerto total. Dada quando:

Diagnóstico foi correto.

Diagnóstico correto interrogado com descrição da alteração correta.

- Nota 1: acerto parcial. Dada quando:

Diagnóstico incorreto porém com descrição correta da lesão.

Diagnóstico correto interrogado com descrição incompleta.

- Nota 0: incorreção no diagnóstico. Dada quando:

Diagnóstico incorreto sem descrição ou com descrição incompleta da lesão. 
Os dois juízes realizaram as avaliações das respostas individualmente e, nos casos em que houve diferença nas notas, um consenso foi feito entre eles, de maneira a se chegar a uma avaliação unificada.

\subsection{Análise estatística}

Para análise estatística da concordância das respostas foi utilizado o Coeficiente Kappa, descrito por COHEN (1960) para avaliar o grau de acerto do procedimento, ou seja, o quanto o resultado escapa do azar. Um coeficiente de 0,75 a 1 foi considerado muito bom, entre 0,4 e 0,74 foi considerado regular a bom e menor que 0,35 considerado ruim.

Para as análises que requereram mais de 2 instâncias, como nos casos de escores, foi utilizado uma variante denominada coeficiente Kappa ponderado.

Nos casos das análises dos escores de qualidade dos DVDs A e B e na análise do acerto do diagnóstico, foram sintetizados os escores dados pelos 3 examinadores do mesmo DVD em um único escore, o de maior freqüência entre o grupo. Quando cada examinador atribuiu um escore diferente, foram desprezados os escores extremos.

Admitiu-se nível de significância $p<0,05$. A análise estatística foi realizada com o programa Stata versão 8.0. 


\section{RESULTADOS}

\subsection{Avaliação do DVD de images pareadas (DVDPAR)}

\subsubsection{Qual das duas imagens do par é a melhor?}

A Tabela 6 mostra as respostas dadas por cada um dos 6 examinadores sobre qual das duas imagens do par ( $\mathrm{A}$ ou B) tem melhor qualidade, ou se ambas têm a mesma qualidade. Na última coluna vemos qual das imagens do par era a de VC ou se nenhuma delas. 
TABELA 6 - RESPOSTAS DOS EXAMINADORES SOBRE QUAL DAS IMAGENS DO PAR TEM MELHOR QUALIDADE (A OU B) *

\begin{tabular}{cccccccc}
\hline $\begin{array}{c}\text { par de } \\
\text { imagem }\end{array}$ & $\begin{array}{c}\text { exam. } \\
\mathbf{1}\end{array}$ & $\begin{array}{c}\text { exam. } \\
\mathbf{2}\end{array}$ & $\begin{array}{c}\text { exam. } \\
\mathbf{3}\end{array}$ & $\begin{array}{c}\text { exam. } \\
\mathbf{4}\end{array}$ & $\begin{array}{c}\text { exam. } \\
\mathbf{5}\end{array}$ & $\begin{array}{c}\text { exam. } \\
\mathbf{6}\end{array}$ & $\begin{array}{c}\text { imagem } \\
\text { de VC }\end{array}$ \\
\hline 1 & $\mathrm{~B}$ & $\mathrm{~B}$ & $\mathrm{~B}$ & $=$ & $\mathrm{B}$ & $\mathrm{B}$ & $\mathrm{A}$ \\
2 & $\mathrm{~A}$ & $\mathrm{~A}$ & $\mathrm{~A}$ & $\mathrm{~A}$ & $\mathrm{~A}$ & $\mathrm{~A}$ & $\mathrm{~B}$ \\
3 & $\mathrm{~B}$ & $\mathrm{~B}$ & $\mathrm{~B}$ & $=$ & $\mathrm{B}$ & $=$ & $\mathrm{A}$ \\
4 & $\mathrm{~B}$ & $\mathrm{~B}$ & $\mathrm{~B}$ & $\mathrm{~B}$ & $\mathrm{~B}$ & $\mathrm{~B}$ & $\mathrm{~A}$ \\
5 & $=$ & $=$ & $=$ & $=$ & $=$ & $=$ & - \\
6 & $\mathrm{~B}$ & $\mathrm{~B}$ & $\mathrm{~B}$ & $=$ & $\mathrm{B}$ & $=$ & $\mathrm{A}$ \\
7 & $=$ & $=$ & $=$ & $=$ & $=$ & $=$ & - \\
8 & $\mathrm{~A}$ & $\mathrm{~A}$ & $\mathrm{~A}$ & $\mathrm{~A}$ & $\mathrm{~A}$ & $\mathrm{~A}$ & $\mathrm{~B}$ \\
9 & $\mathrm{~A}$ & $\mathrm{~A}$ & $\mathrm{~A}$ & $=$ & $\mathrm{A}$ & $\mathrm{A}$ & $\mathrm{B}$ \\
10 & $=$ & $\mathrm{B}$ & $=$ & $=$ & $\mathrm{B}$ & $=$ & $\mathrm{A}$ \\
11 & $\mathrm{~A}$ & $\mathrm{~A}$ & $\mathrm{~A}$ & $\mathrm{~A}$ & $\mathrm{~A}$ & $\mathrm{~A}$ & $\mathrm{~B}$ \\
12 & $=$ & $=$ & $=$ & $=$ & $=$ & $=$ & - \\
13 & $\mathrm{~A}$ & $\mathrm{~A}$ & $\mathrm{~A}$ & $\mathrm{~A}$ & $\mathrm{~A}$ & $\mathrm{~A}$ & $\mathrm{~B}$ \\
14 & $=$ & $=$ & $=$ & $=$ & $=$ & $=$ & - \\
15 & $\mathrm{~B}$ & $\mathrm{~B}$ & $\mathrm{~B}$ & $\mathrm{~B}$ & $\mathrm{~B}$ & $\mathrm{~B}$ & $\mathrm{~A}$ \\
16 & $\mathrm{~B}$ & $\mathrm{~B}$ & $\mathrm{~B}$ & $\mathrm{~B}$ & $\mathrm{~B}$ & $\mathrm{~B}$ & $\mathrm{~A}$ \\
17 & $\mathrm{~B}$ & $\mathrm{~B}$ & $\mathrm{~B}$ & $\mathrm{~B}$ & $\mathrm{~B}$ & $\mathrm{~B}$ & $\mathrm{~A}$ \\
18 & $\mathrm{~A}$ & $\mathrm{~A}$ & $\mathrm{~A}$ & $\mathrm{~A}$ & $\mathrm{~A}$ & $\mathrm{~A}$ & $\mathrm{~B}$ \\
19 & $=$ & $=$ & $=$ & $=$ & $=$ & $=$ & - \\
20 & $\mathrm{~B}$ & $\mathrm{~B}$ & $\mathrm{~B}$ & $=$ & $\mathrm{B}$ & $\mathrm{B}$ & $\mathrm{A}$ \\
21 & $\mathrm{~A}$ & $\mathrm{~A}$ & $\mathrm{~A}$ & $\mathrm{~A}$ & $\mathrm{~A}$ & $\mathrm{~A}$ & $\mathrm{~B}$ \\
22 & $\mathrm{~B}$ & $\mathrm{~B}$ & $\mathrm{~B}$ & $\mathrm{~B}$ & $\mathrm{~B}$ & $\mathrm{~B}$ & $\mathrm{~A}$ \\
23 & $\mathrm{~A}$ & $\mathrm{~A}$ & $\mathrm{~A}$ & $\mathrm{~A}$ & $\mathrm{~A}$ & $\mathrm{~A}$ & $\mathrm{~B}$ \\
24 & $=$ & $=$ & $=$ & $=$ & $=$ & $=$ & - \\
25 & $\mathrm{~B}$ & $\mathrm{~B}$ & $\mathrm{~B}$ & $\mathrm{~B}$ & $\mathrm{~B}$ & $\mathrm{~B}$ & $\mathrm{~A}$ \\
26 & $\mathrm{~A}$ & $\mathrm{~A}$ & $\mathrm{~A}$ & $\mathrm{~A}$ & $\mathrm{~A}$ & $\mathrm{~A}$ & $\mathrm{~B}$ \\
\hline
\end{tabular}

* Na última coluna quais imagens eram de VC (“-“ indica que nenhuma delas era de VC). Imagens 1 a 13 eram fibroscopias. Imagens 14 a 26 telescopias. Para as colunas com examinadores: A-melhor imagem é A; B-melhor imagem é B; "="-imagens iguais

A Tabela 7 mostra os resultados da concordância entre as respostas dos 6 examinadores sobre qual das imagens apresenta melhor qualidade, medida pelo coeficiente Kappa. Foram obtidos 156 resultados no total (6 examinadores observaram 26 pares), sendo 78 fibroscopias e 78 telescopias. A última coluna mostra as porcentagens dos resultados, em relação ao total, que apontaram a imagem original como sendo a de melhor qualidade. Nenhum examinador achou que a imagem de VC apresentava melhor qualidade que a original. Todas os casos de discordâncias se deram 
no sentido de que as imagens apresentavam a mesma qualidade quando, na verdade, uma delas era de VC.

TABELA 7 - CONCORDÂNCIA ENTRE AS RESPOSTAS DOS 6 EXAMINADORES SOBRE QUAL DAS IMAGENS APRESENTA MELHOR QUALIDADE.

\begin{tabular}{ccc}
\hline laringoscopias & $\begin{array}{c}\text { concordância dos } \\
\text { examinadores } \\
\mathbf{K}(\mathbf{p})\end{array}$ & original melhor \\
\hline fibroscopias+telescopias & $0,850(p<0,001)$ & $92,95 \%$ \\
fibroscopias & $0,736(p<0,001)$ & $87,17 \%$ \\
telescopias & $0,960(p<0,001)$ & $98,71 \%$ \\
\hline
\end{tabular}

$\mathrm{K}=$ coeficiente Kappa

p=índice de significância

\subsubsection{A diferença das imagens afeta o diagnóstico?}

A Tabela 8 mostra as respostas dadas por cada um dos 6 examinadores sobre se a diferença na qualidade das duas imagens do par (A ou B) afeta a capacidade do examinador em realizar o diagnóstico. $\mathrm{Na}$ última coluna vemos qual das imagens do par era a de VC ou se nenhuma delas. 
TABELA 8 - RESPOSTAS DOS EXAMINADORES SOBRE SE A DIFERENÇA NA QUALIDADE DAS IMAGES AFETA UM CORRETO DIAGNÓSTICO *

\begin{tabular}{|c|c|c|c|c|c|c|c|}
\hline $\begin{array}{c}\text { par de } \\
\text { imagem }\end{array}$ & $\begin{array}{c}\text { exam. } \\
1\end{array}$ & $\begin{array}{c}\text { exam. } \\
2\end{array}$ & $\begin{array}{c}\text { exam. } \\
3\end{array}$ & $\begin{array}{c}\text { exam. } \\
4\end{array}$ & $\begin{array}{c}\text { exam. } \\
5\end{array}$ & $\begin{array}{c}\text { exam. } \\
6\end{array}$ & $\begin{array}{c}\text { imagem } \\
\text { de VC }\end{array}$ \\
\hline 1 & $\mathrm{~N}$ & $\mathrm{~N}$ & $\mathrm{~N}$ & $\mathrm{~N}$ & $\mathrm{~N}$ & $\mathrm{~N}$ & $A$ \\
\hline 2 & $S$ & $S$ & $S$ & $S$ & $S$ & $S$ & $B$ \\
\hline 3 & $\mathrm{~N}$ & $\mathrm{~N}$ & $\mathrm{~N}$ & $\mathrm{~N}$ & $\mathrm{~N}$ & $\mathrm{~N}$ & $A$ \\
\hline 4 & $S$ & $S$ & $S$ & $\mathrm{~N}$ & $S$ & $\mathrm{~N}$ & $A$ \\
\hline 5 & $\mathrm{~N}$ & $\mathrm{~N}$ & $\mathrm{~N}$ & $\mathrm{~N}$ & $\mathrm{~N}$ & $\mathrm{~N}$ & - \\
\hline 6 & $\mathrm{~N}$ & $\mathrm{~N}$ & $\mathrm{~N}$ & $\mathrm{~N}$ & $\mathrm{~N}$ & $\mathrm{~N}$ & A \\
\hline 7 & $\mathrm{~N}$ & $\mathrm{~N}$ & $N$ & $\mathrm{~N}$ & $\mathrm{~N}$ & $\mathrm{~N}$ & - \\
\hline 8 & $S$ & $S$ & $S$ & $\mathrm{~N}$ & $S$ & $S$ & $B$ \\
\hline 9 & $\mathrm{~N}$ & $\mathrm{~N}$ & $\mathrm{~N}$ & $\mathrm{~N}$ & $S$ & $\mathrm{~N}$ & $B$ \\
\hline 10 & $\mathrm{~N}$ & $\mathrm{~N}$ & $\mathrm{~N}$ & $\mathrm{~N}$ & $\mathrm{~N}$ & $\mathrm{~N}$ & $A$ \\
\hline 11 & $\mathrm{~N}$ & $S$ & $S$ & $\mathrm{~N}$ & $\mathrm{~N}$ & $\mathrm{~N}$ & $B$ \\
\hline 12 & $\mathrm{~N}$ & $\mathrm{~N}$ & $\mathrm{~N}$ & $\mathrm{~N}$ & $\mathrm{~N}$ & $\mathrm{~N}$ & - \\
\hline 13 & $\mathrm{~N}$ & $\mathrm{~N}$ & $\mathrm{~N}$ & $\mathrm{~N}$ & $\mathrm{~N}$ & $\mathrm{~N}$ & B \\
\hline 14 & $\mathrm{~N}$ & $\mathrm{~N}$ & $\mathrm{~N}$ & $\mathrm{~N}$ & $\mathrm{~N}$ & $\mathrm{~N}$ & - \\
\hline 15 & $\mathrm{~N}$ & $\mathrm{~N}$ & $\mathrm{~N}$ & $\mathrm{~N}$ & $\mathrm{~N}$ & $S$ & $A$ \\
\hline 16 & $S$ & $\mathrm{~N}$ & $\mathrm{~N}$ & $\mathrm{~N}$ & $S$ & $S$ & $A$ \\
\hline 17 & $\mathrm{~N}$ & $\mathrm{~N}$ & $\mathrm{~N}$ & $\mathrm{~N}$ & $S$ & $\mathrm{~N}$ & $A$ \\
\hline 18 & $S$ & $\mathrm{~N}$ & $S$ & $\mathrm{~N}$ & $S$ & $\mathrm{~N}$ & B \\
\hline 19 & $\mathrm{~N}$ & $\mathrm{~N}$ & $\mathrm{~N}$ & $\mathrm{~N}$ & $\mathrm{~N}$ & $\mathrm{~N}$ & - \\
\hline 20 & $\mathrm{~N}$ & $\mathrm{~N}$ & $\mathrm{~N}$ & $\mathrm{~N}$ & $S$ & $\mathrm{~N}$ & $A$ \\
\hline 21 & $\mathrm{~N}$ & $\mathrm{~N}$ & $\mathrm{~N}$ & $\mathrm{~N}$ & $S$ & $\mathrm{~N}$ & $B$ \\
\hline 22 & $\mathrm{~N}$ & $\mathrm{~N}$ & $\mathrm{~N}$ & $\mathrm{~N}$ & $S$ & $\mathrm{~N}$ & $A$ \\
\hline 23 & $\mathrm{~N}$ & $\mathrm{~N}$ & $\mathrm{~N}$ & $\mathrm{~N}$ & $\mathrm{~N}$ & $\mathrm{~N}$ & $B$ \\
\hline 24 & $\mathrm{~N}$ & $\mathrm{~N}$ & $\mathrm{~N}$ & $\mathrm{~N}$ & $\mathrm{~N}$ & $\mathrm{~N}$ & - \\
\hline 25 & $\mathrm{~N}$ & $S$ & $\mathrm{~N}$ & $\mathrm{~N}$ & $S$ & $\mathrm{~N}$ & $A$ \\
\hline 26 & $\mathrm{~N}$ & $\mathrm{~N}$ & $\mathrm{~N}$ & $\mathrm{~N}$ & $\mathrm{~N}$ & $\mathrm{~N}$ & $B$ \\
\hline
\end{tabular}

A Tabela 9 mostra a concordância entre as respostas dos 6 examinadores sobre, se houver diferença de qualidade entre as imagens A e B, se esta afeta o diagnóstico correto, medida pelo coeficiente Kappa. A última coluna mostra o percentual em que não interfere no diagnóstico.

Observamos que a concordância entre as respostas foi boa nas fibroscopias e ruim nas telescopias. 
TABELA 9 - CONCORDÂNCIA ENTRE AS RESPOSTAS DOS 6 EXAMINADORES SOBRE SE A DIFERENÇA NA QUALIDADE DAS IMAGENS AFETA O DIAGNÓSTICO.

\begin{tabular}{ccc}
\hline laringoscopias & $\begin{array}{c}\text { concordância dos } \\
\text { examinadores } \\
\mathbf{K}(p)\end{array}$ & $\begin{array}{c}\text { diferença não afeta o } \\
\text { diagnóstico }\end{array}$ \\
\hline fibroscopias+telescopias & $0,371(p<0,001)$ & $75,64 \%$ \\
fibroscopias & $0,624(p<0,001)$ & $76,92 \%$ \\
telescopias & $0,060(p=0,201)$ & $74,35 \%$ \\
\hline
\end{tabular}

$\mathrm{K}=$ coeficiente Kappa

$\mathrm{p}=$ =índice de significância

\subsubsection{Qual das imagens é a de VC?}

A Tabela 10 mostra as respostas dadas por cada um dos 6 examinadores sobre qual das imagens do par (A ou B) é a de VC. Na última coluna vemos qual das imagens do par era a de VC ou se nenhuma delas. 
TABELA 10 - RESPOSTAS DOS EXAMINADORES SOBRE QUAL DAS IMAGENS DO PAR É A DE VC (A OU B) *

\begin{tabular}{cccccccc}
\hline $\begin{array}{c}\text { par de } \\
\text { imagem }\end{array}$ & $\begin{array}{c}\text { exam. } \\
\mathbf{1}\end{array}$ & $\begin{array}{c}\text { exam. } \\
\mathbf{2}\end{array}$ & $\begin{array}{c}\text { exam. } \\
\mathbf{3}\end{array}$ & $\begin{array}{c}\text { exam. } \\
\mathbf{4}\end{array}$ & $\begin{array}{c}\text { exam. } \\
\mathbf{5}\end{array}$ & $\begin{array}{c}\text { exam. } \\
\mathbf{6}\end{array}$ & $\begin{array}{c}\text { imagem } \\
\text { de VC }\end{array}$ \\
\hline 1 & A & A & A & - & A & A & A \\
2 & B & B & B & B & B & B & B \\
3 & B & A & A & - & A & A & A \\
4 & A & A & A & A & A & A & A \\
5 & - & - & - & - & - & - & - \\
6 & A & A & A & A & A & A & A \\
7 & - & - & - & - & - & - & - \\
8 & B & B & B & B & B & B & B \\
9 & B & B & B & B & B & B & B \\
10 & - & A & - & - & A & A & A \\
11 & B & B & B & B & B & B & B \\
12 & - & - & - & - & - & - & - \\
13 & B & B & B & B & B & B & B \\
14 & - & - & - & - & - & - & - \\
15 & A & A & A & A & A & A & A \\
16 & A & A & A & A & A & A & A \\
17 & A & A & A & A & A & A & A \\
18 & B & B & B & B & B & B & B \\
19 & - & - & - & - & - & - & - \\
20 & A & A & A & A & A & A & A \\
21 & B & B & B & B & B & B & B \\
22 & A & A & A & A & A & A & A \\
23 & B & B & B & B & B & B & B \\
24 & - & - & - & - & - & - & - \\
25 & A & A & A & A & A & A & A \\
26 & B & B & B & B & B & B & B \\
\hline
\end{tabular}

*. Na última coluna quais imagens eram de VC ("-“ indica que nenhuma delas era de VC). Imagens 1 a 13 eram fibroscopias. Imagens 14 a 26 telescopias. Para as colunas com examinadores: A-a imagem de VC é A; B-a imagem de VC é B; "-“- nenhuma das imagens é de VC

A Tabela 11 mostra os resultados da concordância entre as respostas dos 6 examinadores sobre qual das imagens era a de VC, medida pelo coeficiente Kappa. A última coluna mostra as porcentagens dos resultados, em relação ao total, que apontaram corretamente qual das imagens era a de VC.

Os examinadores não tiveram dificuldades em saber qual das duas imagens era de VC, apresentando concordância muito boa tanto em fibroscopias $(K=0,821)$, como em telescopias $(K=1,000)$. 
TABELA 11 - CONCORDÂNCIA ENTRE AS RESPOSTAS DOS 6 EXAMINADORES SOBRE QUAL DAS IMAGENS DO PAR FOI TRANSMITIDA POR VC.

\begin{tabular}{ccc}
\hline laringoscopias & $\begin{array}{c}\text { concordância dos } \\
\text { examinadores } \\
\mathbf{K}(\mathbf{p})\end{array}$ & qual é a de VCr \\
\hline fibroscopias+telescopias & $0,911(p<0,001)$ & $96,15 \%$ \\
fibroscopias & $0,821(p<0,001)$ & $92,30 \%$ \\
telescopias & $1,000(p<0,001)$ & $100,00 \%$ \\
\hline
\end{tabular}

$\mathrm{K}=$ coeficiente Kappa

p=índice de significância

\subsection{Resultados da análise da qualidade da imagem nos DVDs A e B :}

A Tabela 12 mostra a distribuição de todas imagens (telescopias + fibroscopias) baseada nos escores de qualidade atribuídos pelos examinadores que as viram por VC (na vertical) e originais (na horizontal). Nas células o valor superior corresponde ao número absoluto de imagens e o valor inferior à porcentagem em relação ao total de imagens. A diagonal principal da tabela corresponde às imagens onde houve concordância absoluta nos escores de qualidade entre a imagem original e VC (3 para original e 3 para $\mathrm{VC}, 2$ para original e 2 para $\mathrm{VC}$, e assim sucessivamente). O coeficiente de concordância kappa para todas as imagens (fibroscopias + telescopias) foi $\mathrm{K}=0,219(\mathrm{p}<0,001)$. 
TABELA 12 - ESCORES DE QUALIDADE DAS IMAGENS ORIGINAIS E VC NAS VIDEOLARINGOSCOPIAS (FIBROSCOPIAS + TELESCOPIAS) *

\begin{tabular}{|c|c|c|c|c|c|c|}
\hline & \multicolumn{5}{|c|}{ imagem original } \\
\hline & & 0 & 1 & 2 & 3 & total \\
\hline \multirow{10}{*}{ 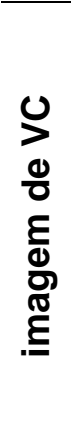 } & \multirow{2}{*}{0} & 0 & 3 & 2 & 1 & 6 \\
\hline & & $0,00 \%$ & $5,00 \%$ & $3,33 \%$ & $1,67 \%$ & $10,00 \%$ \\
\hline & \multirow{2}{*}{1} & 0 & 2 & 8 & 11 & 21 \\
\hline & & $0,00 \%$ & $3,33 \%$ & $13,33 \%$ & $18,33 \%$ & $35,00 \%$ \\
\hline & \multirow{2}{*}{2} & 0 & 05 & 7 & 25 & 32 \\
\hline & & $0,00 \%$ & $0,00 \%$ & $11,67 \%$ & $41,67 \%$ & $53,33 \%$ \\
\hline & \multirow{2}{*}{3} & 0 & 0 & 0 & 1 & 1 \\
\hline & & $0,00 \%$ & $0,00 \%$ & $0,00 \%$ & $1,67 \%$ & $1,67 \%$ \\
\hline & \multirow{2}{*}{ total } & 0 & 5 & 17 & 38 & 60 \\
\hline & & $0,00 \%$ & $8,33 \%$ & $28,33 \%$ & $63,33 \%$ & $100,00 \%$ \\
\hline
\end{tabular}

${ }^{*}$ Escore: 0 = ruim; $1=$ regular; $2=$ boa; 3=ótima

As Tabelas 13 e 14 mostram a distribuição dos escores das imagens de fibrosopia e telescopia respectivamente.

O coeficiente de concordância Kappa apenas para as fibroscopias foi $K=0,249(p<0,005)$ e de telescopias foi $K=0,059(p=0,081)$.

TABELA 13 - ESCORES DE QUALIDADE DAS IMAGENS ORIGINAIS E VC NAS FIBROSCOPIAS *

\begin{tabular}{|c|c|c|c|c|c|c|}
\hline & \multicolumn{5}{|c|}{ imagem original } \\
\hline & & 0 & 1 & 2 & 3 & total \\
\hline \multirow{10}{*}{ 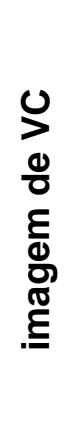 } & \multirow{2}{*}{0} & 0 & 3 & 1 & 1 & 5 \\
\hline & & $0,00 \%$ & $10,00 \%$ & $3,33 \%$ & $3,33 \%$ & $16,67 \%$ \\
\hline & \multirow{2}{*}{1} & 0 & 2 & 7 & 5 & 14 \\
\hline & & $0,00 \%$ & $6,67 \%$ & $23,33 \%$ & $16,67 \%$ & $46,67 \%$ \\
\hline & \multirow{2}{*}{2} & 0 & 0 & 4 & 6 & 10 \\
\hline & & $0,00 \%$ & $0,00 \%$ & $13,33 \%$ & $20,00 \%$ & $33,33 \%$ \\
\hline & \multirow{2}{*}{3} & 0 & 0 & 0 & 1 & 1 \\
\hline & & $0,00 \%$ & $0,00 \%$ & $0,00 \%$ & $3,33 \%$ & $3,33 \%$ \\
\hline & \multirow[t]{2}{*}{ total } & 0 & 5 & 12 & 13 & 30 \\
\hline & & $0,00 \%$ & $16,67 \%$ & $40,00 \%$ & $43,33 \%$ & $100,00 \%$ \\
\hline
\end{tabular}

${ }^{*}$ Escore: 0 = ruim; $1=$ regular; $2=$ boa; 3=ótima 
TABELA 14 - ESCORES DE QUALIDADE DAS IMAGENS ORIGINAIS E VC NAS TELESCOPIAS*

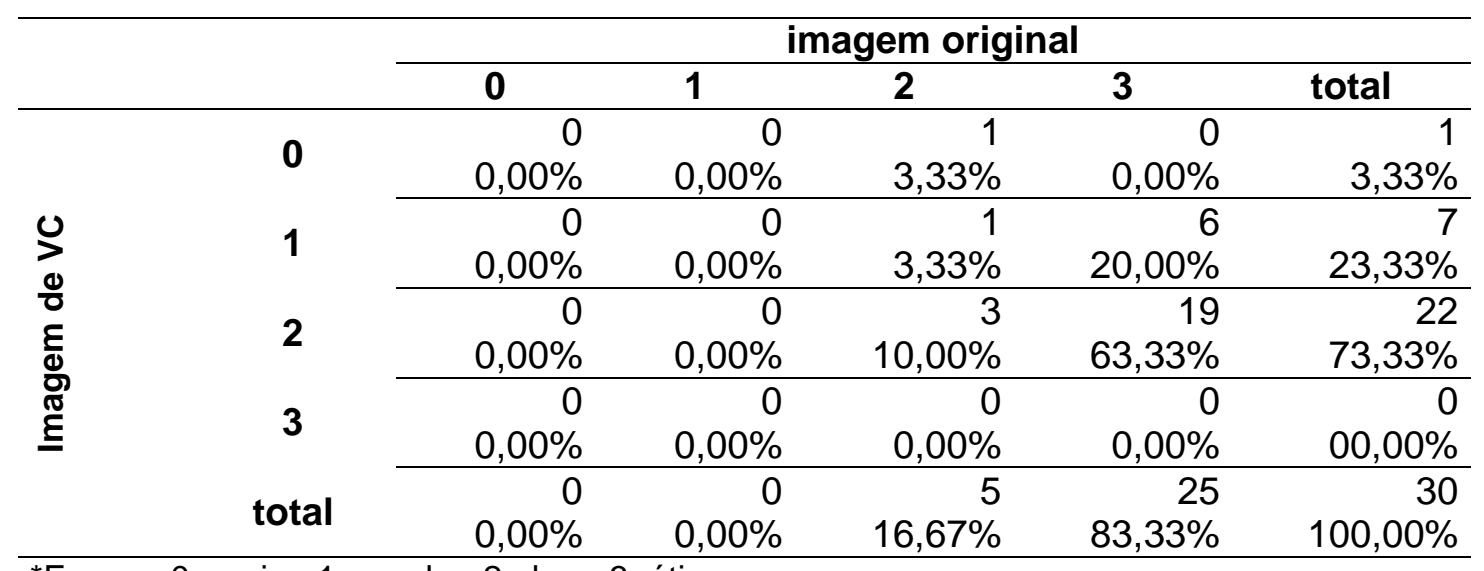

${ }^{\star}$ Escore: 0 = ruim; $1=$ regular; $2=$ boa; 3=ótima

\subsection{Concordância diagnóstica nos DVDs A e B}

O coeficiente de concordânica Kappa para os acertos diagnósticos de fibroscopias e telescopias foi $K=0,293$ com $p<0,001$.

A Tabela 15 mostra a freqüência total de acerto de diagnóstico dos examinadores que viram as imagens por VC (na vertical) e originais (na horizontal). Nas células o valor superior corresponde ao número absoluto de imagens e o valor inferior à porcentagem em relação ao número total de imagens. A diagonal principal da tabela corresponde às imagens onde houve concordância absoluta nos acertos (acerto completo para original e VC, acerto parcial para original e VC, ou erro para original e VC). 
TABELA 15 - ACERTO DIAGNÓSTICO DOS EXAMINADORES NAS IMAGENS DE FIBROSCOPIAS E TELESCOPIAS *

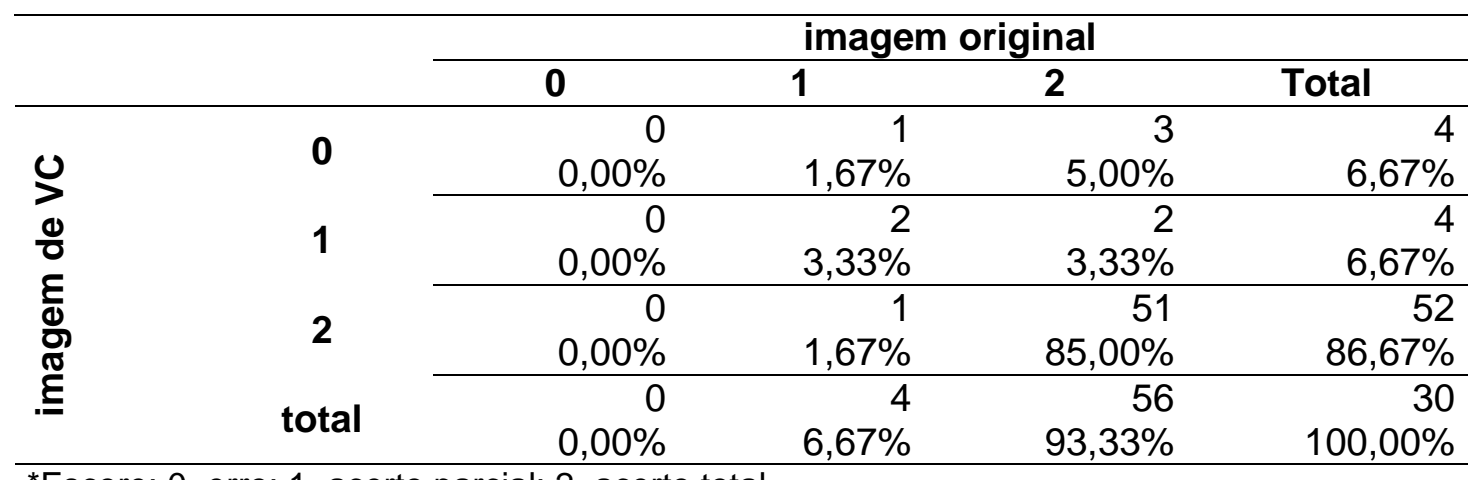

*Escore: $0=$ erro; $1=$ acerto parcial; 2=acerto total

As Tabelas 16 e 17 mostram a freqüência de acerto de diagnóstico pelos examinadores nas fibroscopias e telescopias respectivamente.

O coeficiente Kappa para os acertos diagnósticos de fibroscopias foi $K=0,561(p<0,005)$ e para telescopias foi $K=0,114(p=0,09)$.

TABELA 16 - ACERTO DIAGNÓSTICO DOS EXAMINADORES NAS IMAGENS DE FIBROSCOPIAS *

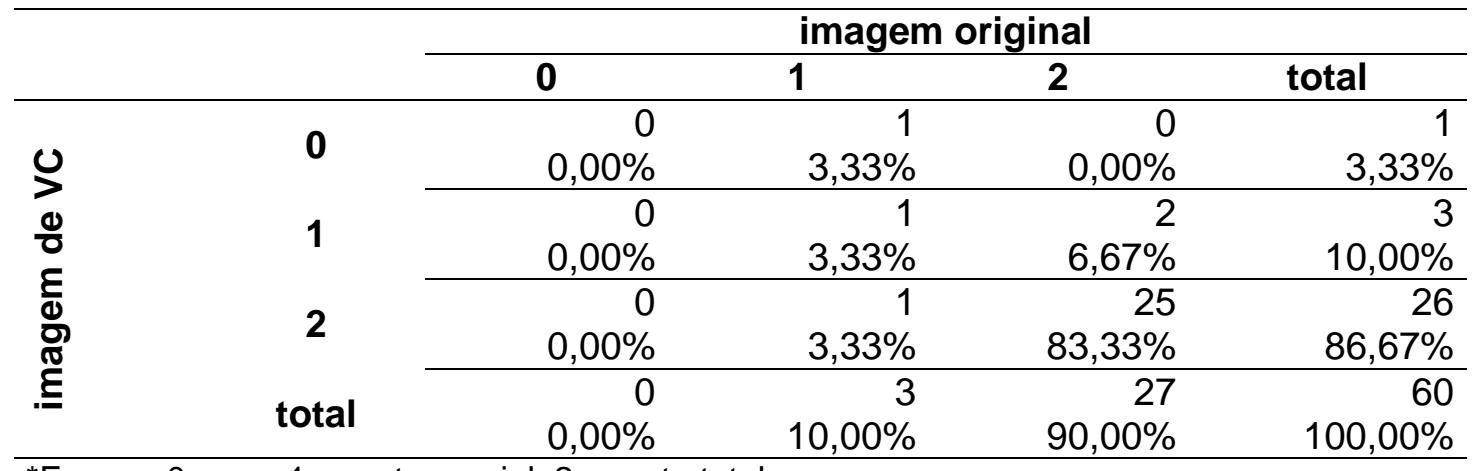

*Escore: $0=$ =rro; $1=$ acerto parcial; $2=$ =acerto total 
TABELA 17 - ACERTO DIAGNÓSTICO DOS EXAMINADORES NAS IMAGENS DE TELESCOPIAS*

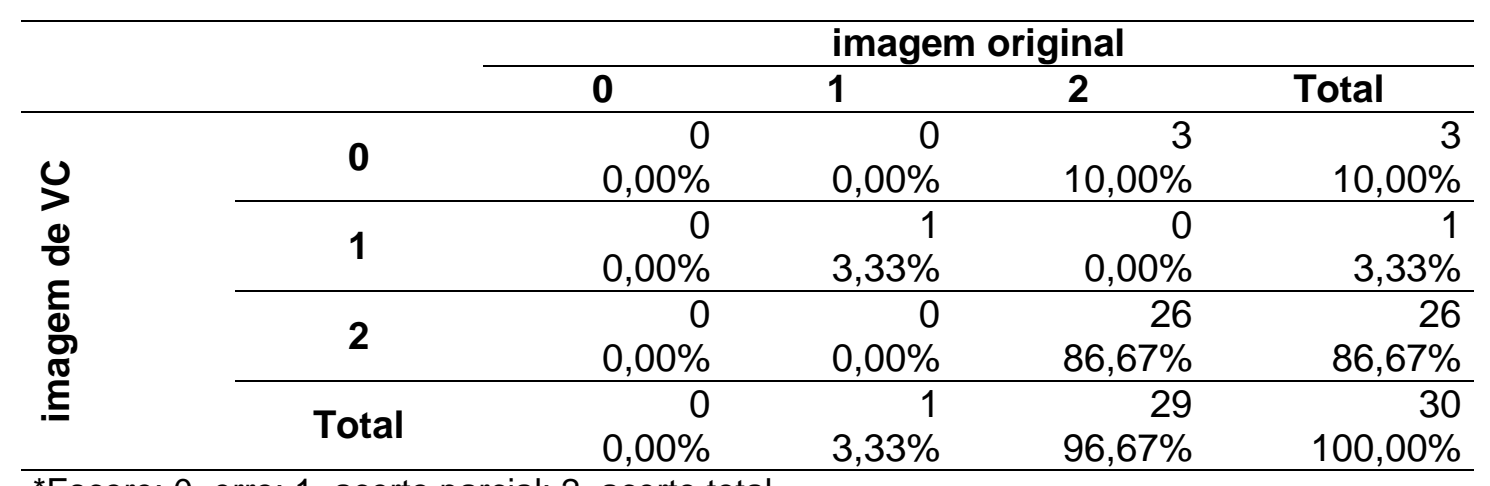

*Escore: $0=$ erro; $1=$ acerto parcial; 2=acerto total 


\section{DISCUSSÃO}

Atualmente todo material multimídia, principalmente áudio ou vídeo pode ser capturado e convertido em formato digital (códigos numéricos de 2 dígitos), sem perda ou com perdas mínimas de qualidade, dependendo do método de captura digital empregado. (NUNES et al., 1998, MANDEL et al., 1997)

Após a digitalização cada quadro do vídeo é uma imagem estática que é pixalisada, ou seja, a imagem é subdividida em pequenas unidades (pixel) que armazenam suas informações. A qualidade do vídeo digitalizado vai depender da quantidade de quadros capturados por segundo e da qualidade de cada quadro, que pode ser exprimida pela quantidade de pixels utilizados (dimensão da tela) e da quantidade de informação em cada pixel (variação das cores).

Esta digitalização requer grande espaço de armazenamento. Portanto para sua transmissão ser viável é necessário que haja uma redução do volume de informações desta imagem ao mínimo (PEDERSEN et al., 1994). Para isso é necessário a utilização de CODECs (codificador / decodificador), sistemas baseados em algoritmos matemáticos para compressão de dados redundantes antes de serem transmitidos, reduzindo a quantidade de 
informações a serem transmitidas (LEOPOLDINO, 2001). Uma correspondente "analogização" da imagem ocorre com um segundo CODEC instalado no ponto receptor. Utilizamos neste protocolo o mais utilizado CODEC dos equipamentos de VC atualmente que é o H 320., baseado no Comitê Consultatif International de Telegraphique et Telephonique (CCITT). É o padrão desenvolvido pelo ITU (International Telecommunications Union) para a utilização de multimídia em redes comutadas por pacotes, cujo principal componente é o protocolo de compactação H.263 (BORDIGNON, 2001)

As principais causas de atrasos na entrega de dados de áudio e vídeo por VC são a latência (atraso na propagação dos dados pela rede) e o jitter (entrega de pacotes de dados com latência variável). A largura de banda também determina a qualidade do serviço. Em VC, tem-se que a largura de banda mínima aceitável para o áudio é de 71kbps e para o vídeo 128 kbps (LEOPOLDINO, 2001).

Com uma linha ISDN de 128 kbps é possível transmitir áudio monofônico com qualidade de TV e um vídeo com 15 quadros por segundo, porém incapaz de mostrar movimentos rápidos. Utilizando-se três linhas ISDN (384 kbps), a qualidade é excelente, com 30 quadros por segundo (SABBATINI, 2000).

PEDERSEN et al. (1994) em seu trabalho pioneiro sobre VC em otorrinolaringologia concluiram que um vídeo de tela cheia, de resolução 410x400 necessitaria de 1000 linhas telefônicas para serem conduzidas, porém com a utilização de um CODEC este número poderia ser reduzido em 
97\%, para 32 canais (16 linhas). Mesmo assim, nas circunstâncias atuais, um número realista de linhas que poderiam ser utilizadas para VC diagnóstica seria de 8 canais (4 linhas) ou 512 kbps. É aí que nosso estudo desempenha papel fundamental. É impossível se fazer compressão sem que haja algum tipo de perda nas informações contidas no sinal, resultando em redução tanto na qualidade da imagem como redução do número de cores, embaçamento de estruturas mais delicadas e retardo na atualização dos quadros quando mudanças bruscas de velocidade acontecem. Os autores constataram que esta diferença de qualidade não interfere na habilidade do examinador realizar um diagnóstico correto.

Em nosso estudo utilizamos equipamentos e infra-estrutura rotineiramente disponíveis para a maioria dos serviços e consultórios otorrinolaringológicos.

\subsection{Transmissão das imagens digitalizadas}

A literatura sobre o uso da TM em otorrinolaringologia é escassa, principalmente na laringologia. Este, pelo que conhecemos, é o primeiro estudo de VC que trabalha exclusivamente com imagens de laringe e sua transmissão de maneira dinâmica (vídeo) já que o estudo de FURUKAWA et al. (1998) utilizou apenas imagens estáticas para diagnóstico. SCLAFANI et al. (1999), utilizaram o nasofibroscópio como parte da consulta geral e com transmissão de 384 kpbs. Nós estudamos a transmissão de videolaringoscopias com 512 kbps diferenciando fibroscopias de telescopias. 
Observamos que a imagem transmitida piora quando ocorrem movimentos bruscos das estruturas analisadas, quando a imagem original é escura e quando a imagem ocupa toda a tela. Nestes casos há uma maior quadriculação (pixelização) da imagem obtida.

\subsection{Utilização de linhas ISDN}

A vídeoconferência é dividida em técnicas ISDN (Integrated Sevices Digital Network) e IP (Internet Protocol) . A diferença está essencialmente em garantir a largura de banda disponível e a confiabilidade da qualidade da imagem. Quando usando ISDN o usuário é capaz de obter do provedor de serviços de telecomunicações uma largura de banda garantida na rede em demanda (COSTA, 2000). Assim, uma vez estabelecida a conexão, a quantidade de tráfego de dados entre o emissor e o receptor, permanece sempre a mesma, ao contrário da transmissão por IP onde o tráfego varia de acordo com a quantidade de usuários no momento da transmissão.

A escolha dos locais de transmissão (FMUSP) e recepção (FMABC) baseou-se nos fatores:

- presença de equipamentos de VC de qualidade em ambos os locais (Tandberg 6000 na FMUSP e Polycom na FMABC).

- disponibilidade de linhas telefônicas no padrão ISDN adequadas para o objetivo do estudo (4 linhas de $128 \mathrm{kbps}$ em cada localidade, totalizando $512 \mathrm{kbps})$ 
- presença de técnicos em ambos os locais já familiarizdos com os equipamentos

- disponibilização de linhas por operadoras distintas: as 4 linhas da FMABC foram disponibilizadas pela empresa EMBRATEL e as 4 linhas da FMUSP pela empresa TELEFONICA

- transmissão intermunicipal

Estes últimos dois fatores favorecem a simulação de uma situação próxima à realidade em boa parte dos casos de VC onde freqüentemente temos operadoras distintas nos pontos locais e remoto dependendo da localização geográfica da região.

\subsection{Análise da comparação de qualidade das imagens no DVDPAR}

Ao examinarmos os resultados individualmente observamos que nenhum dos examinadores achou que a qualidade da imagem de VC foi melhor que a original. (Tabela 6)

O coeficiente de concordância Kappa foi muito bom tanto para fibroscopias como para telescopias (Tabela 7)

Todas as discordâncias encontradas foram de examinadores que acharam que as imagens eram iguais, porém uma delas havia sido transmitida por VC, mostrando que a qualidade da imagem de VC era suficientemente boa para passar por original.

Encontramos discordâncias em 5 fibroscopias e 1 telescopia. Esta diferença de discordâncias entre fibroscopias e telescopias (sempre para 
melhor) pode ser explicada pelo fato de em todas as fibroscopias haver uma região circundante escura e constante pelo uso do coupler e do diâmetro da lente do fibroscópio. Esta região não é considerada ativa pelo CODEC de compressão de vídeo que mantem toda sua capacidade de processamento na região dinâmica e central melhorando a qualidade de transmissão final. Além disso vimos que nas imagens em que existe muito movimento houve maior número de discordância entre os examinadores. Nas telescopias a imagem de tela cheia e movimentação simultânea de mais pontos na tela provoca uma dispersão na capacidade de processamento do CODEC levando a uma pequena perda de qualidade fazendo que os examinadores percebam a diferença mais facilmente.

\subsection{Implicação da diferença da qualidade da imagem no diagnóstico}

O coeficiente Kappa neste estudo foi $\mathrm{K}=0,371$ (Tabela 9) demonstrando haver uma concordância regular entre os examinadores. Para as fibroscopias obteve-se o valor $K=0,624$ e para as telescopias $K=0,060$. Nos exames de fibroscopia, dos 78 resultados dos 6 examinadores, 60 deles (76,92\%) apontaram não haver influência no diagnóstico. Destes resultados, apenas 3 imagens foram consideradas inadequadas por 3 ou mais examinadores. Duas delas apresentavam qualidade inicial da imagem ruim (exame mal realizado) e grande movimentação do paciente. Na outra imagem, além do exame inicial ter sido mal realizado, boa parte do exame 
foi feito com estroboscopia, tornando a imagem excessivamente escura e de diícil visualização.

Nos exames de telescopia, 58 resultados (74,35\%) apontaram não haver influencian no diagnóstico. Destes resultados, apenas 1 imagem foi considerada inadequada por 3 ou mais examinadores. Esta imagem, em tela cheia, com movimentos bruscos simultâneos em todos os pontos da tela, contribui para a dispersão da capacidade de processamento do CODEC, que não se concentra em uma área menor da tela, como nas fibroscopias, provocando alguma pixelização da imagem e redução na sua qualidade.

No caso das telescopias, o examinador número 5 foi considerado extremamente rigoroso na avaliação, considerando que a diferença altera o diagnóstico em 7 dos 13 casos de telescopia, visivelmente bem acima da média dos outros 5 examinadores.

Levando-se em conta os dados apresentados, a diferença entre a qualidade da imagem não interfere significativamente no diagnóstico em $76,92 \%$ nas fibroscopias, $74,35 \%$ nas telescopias mesmo não havendo unanimidade entre os examinadores.

\subsection{Caracterização da imagem como sendo VC}

O coeficiente kappa para as imagens que eram originadas por transmissão via VC foi $K=0,911$ (Tabela 11). Nas fibroscopias foi $K=0,821$. O número de acertos em qual das imagens é a VC foi de 72 em 78 imagens (92,30\%). Nas telescopias $K=1,000$. O número de acertos foi de 78 em 78 
imagens (100\%). Podemos sugerir que os examinadores percebem claramente a diferença entre a imagem original e a que é transmitida por VC, especialmente nas telescopias. Isto era de se esperar já que a imagem transmitida por VC apresenta uma pixelização em maior ou menor grau, de acordo com a movimentação da imagem. Este fato é uma característica do próprio CODEC de compressão da imagem como já explicado anteriormente.

\subsection{Análise da qualidade das imagens dos DVDA e DVDB}

Apesar de termos tentado uma uniformização dos examinadores, escolhendo-se 3 para cada DVD, convidando para o estudo apenas especialistas pela SBORL, com aproximadamente o mesmo tempo de formação e experiência em laringe semelhantes, estamos conscientes de que $\mathrm{o}$ fato de examinadores diferentes avaliarem as imagens originais e VC representa um viés em nosso estudo. Porém, apesar disso e após a adequação da metodologia estatística de sintetização dos escores, observamos pelos resultados que existe uma coerência grande entre os dados obtidos.

Em nenhum caso a qualidade da imagem transmitida por VC foi superior à imagem original. A diferença na qualidade das imagens foi bastante nítida entre as imagens originais e as transmitidas por VC, sempre em favor da imagem original (melhor em $83,33 \%$ das vezes e igual em $16,67 \%$ ), ou seja a transmissão das imagens efetivamente causa uma 
deterioração em maior ou menor grau na qualidade da imagem apresentada previamente à transmissão (Tabela 12)

Nas telescopias essa percepção foi mais evidente $(K=0,059)$, pois em $90,00 \%$ dos casos os examinadores julgaram a imagem de VC pior que a original, enquanto nas fibroscopias foi de 76,67\% (K=0,249). Na telescopia a qualidade da imagem original é tão boa que pequenas alterações na qualidade da VC já são perceptíveis, apesar da qualidade das VC também terem sido boas. Nas telescopias originais $83,33 \%$ de imagens têm qualidade ótima (escore 3) e nas telescopias por VC 73,33\% de imagens são boas (escore 2)(Tabela 14).

Por outro lado, como a qualidade da fibroscopia original já não é tão boa uma pequena queda de qualidade pode não ser percebida. Nas fibroscopias originais 43,33\% têm qualidade ótima (escore 3) e nas fibroscopias por VC $36,66 \%$ são boas ou ótimas (escores 2 ou 3), sendo apenas 1 em 11 com escore 3 (Tabela 13).

Diante do descrito acima podemos concluir que a qualidade das imagens segue na ordem decrescente de qualidade conforme descrito abaixo:
a. Telescopias originais
b. Fibroscopias originais
c. Telescopias VC
d. Fibroscopias VC

A diferença na qualidade pode ser explicada pelo próprio mecanismo de transmissão da imagem no fibroscópio e no telesópio. No fibroscópio a 
imagem é transmitida por um feixe de minúsculas fibras ópticas que conferem à imagem final, depois de amplificada pelo sistema de lentes da ocular, um aspecto granulado e descontínuo característico. No telescópio a imagem é trasmitida por um conjunto de lentes, conferindo à imagem final um aspecto contínuo, sem granulações. Pelo nosso estudo podemos sugerir que a melhor imagem para ser transmitida por VC seria a obtida por um telescópio, porém com "coupler" gerando uma imagem que não ocupasse a tela inteira. Nesta imagem, apesar de menor, a transmissão seria de melhor qualidade pelos aspectos relacionados ao CODEC.

\subsection{Análise do acerto diagnóstico}

Como 3 examinadores viram cada uma das imagens (DVD-A) e os outros 3 viram as imagens complementares (DVD-B), ou seja não viram a mesma imagem, 2 juízes independentes julgaram os diagnósticos e descrições das alterações emitidas por cada grupo de examinadores, para verificar a concordância entre elas.

Independentemente de a imagem ter sido de fibroscopia ou telescopia, a porcentagem de acertos totais em VC foi muito alta para ambos os grupos, $86,67 \%$ nas fibroscopias (Tabela 16 ) e $86,67 \%$ nas telescopias (Tabela 17) levando-se em conta apenas os acertos totais e descartando-se os parciais. Considerando-se acertos totais + parciais alcançaram $96,67 \%$ e $90,00 \%$ respectivamente. 


\subsection{Comentários finais}

Com 512 kpps (4 linhas ISDN) obtivemos achado similar a PEDERSEN, et al. (1994), de que a diferença na qualidade da imagem por VC não interfere na capacidade de um diagnóstico correto. Porém, nosso estudo contempla de uma maneira mais aprofundada o diagnóstico em laringologia, comparando-se endoscópios rígidos e flexíveis e mais próximo à realidade atual para utilização pela grande maioria das instituições (apenas 4 linhas ISDN, e não 16 como Pedersen).

Para otimizar a qualidade de imagem transmitida a 512 kbps, sugerimos a utilização da videotelescopia, porém com coupler que gere uma imagem que não ocupe toda a tela. Fibroscopias também podem ser utilizadas com bons resultados, porém devem ter iluminação adequada e cooperação do paciente para diminuir a movimentação.

FURUKAWA et al. (1998) e sua transmissão com 2 imagens estáticas (uma durante a fonação e outra durante a respiração) considerou que um médico generalista que não um otorrinolaringologista, teria dificuldade em capturar as duas fases da imagem e sugeriu que novas informações fossem dadas. Este estudo supre esta lacuna transmitindo dinamicamente a imagem permitindo que médicos generalistas possam realizar o exame localmente.

Assim, médicos generalistas que não otorrinolaringologistas podem facilmente gravar e transmitir imagens de laringe para especialistas usando endoscópios rígidos e flexíveis (DEWITT, 1988). Desta maneira pode-se transmitir imagens com fidelidade para diagnósticos de regiões distantes e 
carentes de especialistas e mesmo assim conduzir adequadamente e com redução de custos para paciente, médico e instituições públicas, assim como conseguir maior agilidade no diagnóstico de doenças que necessitem tratamento mais urgente. 


\section{CONCLUSÕES}

Comparando videolaringoscopias originais e transmitidas por VC a 512 kbps observamos que:

1. É possível diferenciar imagem original da VC, sendo a diferença mais evidente nas telescopias.

2. A qualidade da VC é pior ou, em alguns casos, igual à original. Em ordem decrescente de qualidade obtivemos:

Telescopias originais

Fibroscopias originais

Telescopias VC

Fibroscopias VC

3. A diferença de qualidade entre a imagem original e VC não interfere no diagnóstico das doenças tanto nas fibroscopias como nas telescopias.

4. A transmissão por VC permite um diagnóstico adequado tanto nas fibroscopias como nas telescopias. 


\section{REFERÊNCIAS BIBLIOGRÁFICAS *}

AAS, I.H. Telemedical work and cooperation. J Telemed Telecare, v.7, p.212-8, 2001.

ALLELY, E.B. Synchronous and asynchronous telemedicine. J Med Syst, v.19, p.207-12, 1995.

BERGMO, T.S. An economic analysis of teleconsultation in otorhinolaryngology. J Telemed Telecare, v.3, p.194-9, 1997.

BIRD, K. Cardiopulmonary frontiers: quality health care via interactive television. Chest, v.61, p.204-5, 1972.

*** De acordo com:

UNIVERSIDADE DE SÃO PAULO. Faculdade de Medicina. Serviço de Biblioteca e documentação. Estrutura e apresentação de teses. Elaborado por Annelise Carneiro da Cunha. São Paulo, Serviço de Biblioteca e Documentação, 1996.

Abreviaturas dos títulos dos periódicos de acordo com LIST OF JOURNAL INDEXED IN INDEX MEDICUS. 
BLAKESLEE, D.B.; GRIST, W.J.; STACHURA, M.E.; BLAKESLEE, B.S.

Practice of otolaryngology via telemedicine. Laryngoscope, v.108, p.1$7,1998$.

BORDIGNON, M.R. Implementando Aplicações de Videoconferência em Redes de Computadores. Disponível em:

http://www.networkdesigners.com.br/Artigos/video/video.html. Acesso em: Junho 2004.

BOWERSOX, J.C. Telerobotics in surgery. In: VIEGAS, S.F.; DUNN, K, ed. TM: Practicing in the information age. Philadelphia, Lippincot-Raven, 1998, P.107-13.

BURGESS, L.P.A.; HOLTEL, M.R.; SYMS, M.J., BIRKMIRE-PETERS, D.P.; PETERS, L.J.; MASHIMA, P.A. Overview of Telemedicine applications for otolaryngology. Laryngoscope, v.109, p.1433-7, 1999

BURGESS, L.P.A.; SYMS, M.J.; HOLTEL, M.R.; BIRKMIRE-PETERS, D.P.; JOHNSON, R.E.; RAMSEY, M.J. Telemedicine: teleproctored endoscopic sinus surgery. Laryngoscope, v.112, p.216-9, 2002.

CHOUINARD, J. Satellite contributions to telemedicine: Canadian CME experiences. Can Med Assoc J, v.128, p.850-5, 1983. 
COHEN, J. A coefficient of agreement for nominal scales. Educ Psychol Meas, v.20, p.37-46, 1960.

COSTA, F.C. Recomendação H.243 - Procedimentos para estabelecer comunicação entre 3 ou mais terminais audiovisuais usando canais digitais de até 1920 kbits/s. Belém, 2000. 128p. Dissertação (Mestrado) - Departamento de Ciência da Computação, Universidade Federal do Pará

CRUMP, W.J.; DRISCOLL, B. An application of telemedicne technology for otorhinolaryngology diagnosis. Laryngoscope, v.106, p.595-8, 1996.

DAKINS, D. Annual checkup indicates healthy market prognosis. Telemed Telehealth Netw, v.4, p.20-2, 24-5, 1998.

DEWITT, D.E. Fiberoptic rhinolaryngoscopy in primary care: a new direction for expanding in-office diagnostics. Postgrad Med, v.84, p.125-44, 1988.

DUFFY, J.R.; WERVEN, G.W.; ARONSON, A.E. Telemedicine and the diagnosis of speech and language disorders. Mayo Clin Proc, v.72, p.1116-22, 1997. 
EIKELBOOM, R.H.; ATLAS, M.D.; MBAO, M.N. Tele-otology: planning, design, development and implementation. J Telemed Telecare, v.53, p.14-7, 2002.

FORTIN, J.P.; GAGNON, M.P.; CLOUTIER, A.; LABBE, F. Evaluation of a telemedicine demonstration project in the Magdalene Islands. $\mathbf{J}$ Telemed Telecare, v.9, p.89-94, 2003.

FRIED, M.P. The challenges and potential of otolaryngological telemedicine. Arch Otolaryngol Head Neck Surg, v.127, p.336, 2001.

FURUKAWA, M.; FURUKAWA, M.K.; MIZOJIRI, G.; MATSUDA, H. Telemedicine in Laryngology. Telemed J, v.4, p.329-33, 1998.

GERSHON-COHEN, J.; COOLEY, A.G. Telegnosis. Radiology, v.55, p.5827, 1950.

GRIGSBY, J.; SANDERS, J.H. Telemedicine. Ann Internal Med. v.129, p.123-7, 1988.

GOLDENBERG, D.; WENIG, B.L. Telemedicine in otolaryngology. Am J Otolaryngol, v.23, p.35-43, 2002. 
HENEGHAN, C.; SCLAFANI, A.P.; STERN, J.; GINSBURG, J. Telemedicine applications in otolaryngology. IEEE Eng Med Biol Mag, v.18, p.53-62, 1999.

HOLTAN, A. Patient reactions to specialist telemedicine consultations - a sociological approach. J Telemed Telecare, v.4, p.206-13, 1998.

HOLTEL, M.R.; BURGESS, L.P.A. Telemedicine in otolaryngology. Otolaryngol Clin North Am, v.35, p.1263-81, 2002.

LEOPOLDINO, G.M. Avaliação de sistemas de videoconferência. São Paulo, 2001. 115 p. Dissertação (Mestrado) - Instituto de Ciências Matemáticas e de Computação de São Carlos, Universidade de São Paulo.

MADE, C.; CARLE, L.; SODERBERG, O.; HELLSTROM, S. Teleotolaryngology consultations between two rural primary-care centres in southern Laoland and the University Hospital of Umea. J Telemed Telecare, v.5, p.593-4, 1999.

MANDEL, A.; SIMON, I.;LYRA, J.L.; Informação: computação e comunicação. Revista USP, v.35, p.11-45, 1997. 
MOORE, M. The evolution of telemedicine. Future Genereation Computer Systems, v.15, p.245-54, 1999.

NATIONAL LIBRARY OF MEDICINE. Medical Subject Headings, 1993

NUNES, L.; MAGALHÃES, A.P.; MADEIRA, S.; NUNES, D.; NOGUEIRA, D.; PASSOS, M.; MACEDO, E. Sistemas pictográficos de comunicação. alternativa para portadores de paralisia cerebral. In: IV Congresso RIBIE, 1998, Brasília.

PATRICOSKI, C.; KOKESH, J.; FERGUSON, A.S.; KOLLER, K.; ZWACK, G.; PROVOST, E.; HOLCK, P. A comparison of in-person examination and video otoscope imaging for tympanostomy tube follow-up. Telemed J E Health, v.9, p.331-44, 2003.

PEDERSEN, S.; HARTVIKSEN, G.; HAGA, D. Teleconsultation of patients with otorhinolaringologic conditions. Arch Otolaryngol Head Neck Surg, v.120, p.133-6, 1994.

PEDERSEN, S.; HOLAND, U. Tele-endoscopic otorhinolaryngological examination: preliminary study of patient satisfaction. Telemed J, v.1, p.47-52, 1995. 
PERENDIA, D.A., Reinventing telemedicine: store-and-forward applications. Telemed Telehealth Netw, v.41, p.15-8, 1996.

RINDE, E.; NORDRUM, I.; NYMO, J. Telemedicine in rural Norway. World Health Forum, v.14, p.71-7, 1993.

SABBATINI, R.M.E. Utilizando Teleconferência em Medicina. Revista Médico Reporter, v.16, p.22-4, 2000.

SCLAFANI A.P.; HENEGHAN, C.; GINSBURG, J.; SABINI, P.; STERN J.; DOLITSKY J.N. Teleconsultation in otolaryngology: live versus store and forward consultations. Otolaryngol Head Neck Surg, v.120, p.62-72, 1999.

STERN, J.; HENEGHAN, C.; SCLAFANI, A.P.; GINSBURG, J.; SABINI, P.; DOLITSKY, J.N. Telemedicine applications in otolaryngology. J Telemed Telecare, v.4, p.74-5,1998.

SYMS, M.J.; SYMS III, C.A. The regular practice of telemedicineTelemedicine in Otolaryngology. Arch Otolaryngol Head Neck Surg, v.127, p.333-6, 2001.

ULLAH, R.; GILLILAND, D.; ADAMS, D. Otolaryngology consultations by real-time medicine. Ulster Med J, v.71, p.26-9, 2002. 
ULOZA, V.; ALMQUIST, L.O.; RYDELL, R.; SVENSSON, O.; ULOZIENE, I. Swedish-Lithuanian telemedicine Litmed project in otolaryngology. Int Congr Ser, v.1240, p.1407-10, 2003.

V.A. SATELLITE EDUCATION PROJECT. Hosp Forum, v.20, p.18, 1978.

VIRRE, E.; WARNER, D.; BALCH, D.; NELSON, J.R. Remote medical consultation for vestibular disorders: Technological solutions and case report. Telemed J, v.3, p.53-8, 1997.

WHEELER, T. Strike up the bandwidth: store \& forward vs. interactive video. Telemed Today, v.6, p.43-4, 1998.

WINTERS, S.R. Diagnosis by wireless. Sci Am, v.11, p.465, 1921.

WITTSON, C.L.; BENSCHOTER, R. Two-way television: helping the medical center reach out. Am J Psychiatry, v.129 p.136-9, 1972. 